\title{
DigITALCOMMONS
}

@WAYNESTATE-

Wayne State University

Wayne State University Dissertations

$1-1-2018$

\section{The Political Landscape: A New Approach To Understanding Corporate Political Activity}

Michael Greiner

Wayne State University,

Follow this and additional works at: https://digitalcommons.wayne.edu/oa_dissertations

Part of the Business Administration, Management, and Operations Commons

\section{Recommended Citation}

Greiner, Michael, "The Political Landscape: A New Approach To Understanding Corporate Political Activity" (2018). Wayne State University Dissertations. 2025.

https://digitalcommons.wayne.edu/oa_dissertations/2025

This Open Access Dissertation is brought to you for free and open access by DigitalCommons@WayneState. It has been accepted for inclusion in Wayne State University Dissertations by an authorized administrator of DigitalCommons@WayneState. 
THE POLITICAL LANDSCAPE: A NEW APPROACH TO UNDERSTANDING CORPORATE POLITICAL ACTIVITY

\author{
by \\ MICHAEL GREINER \\ DISSERTATION \\ Submitted to the Graduate School \\ of Wayne State University, \\ Detroit, Michigan \\ in partial fulfillment of the requirements \\ for the degree of \\ DOCTOR OF PHILOSOPHY
}

2018

MAJOR: BUSINESS ADMINISTRATION

Approved By:

Advisor

Date 


\section{COPYRIGHT BY}

\section{MICHAEL GREINER}

2018

All Rights Reserved 


\section{DEDICATION}

This dissertation is dedicated to Madilyn, the love of my life, without whom none of this would have happened. 


\section{ACKNOWLEDGMENTS}

I owe a deep debt of gratitude to my advisor, Jaegul Lee. It was he who first suggested this topic, and his tireless direction and support throughout the process has been invaluable. I have also been blessed with guidance and advice from my amazing committee, especially Christine Jackson, Scott Julian, and Michael Belzer, as well as the other faculty at the Wayne State University Mike Ilitch School of Business who have helped me throughout my time there, especially Amanuel Tekleab and Attila Yaprak. I also owe a debt of gratitude to the staff of the Mike Ilitch school, particularly Monique Burkman and Brandon Wulf, and I want to especially thank my good friend and fellow student Lyo Laulie, who is the closest thing to a big brother I ever had. Finally, I want to give special thanks to my wife Madilyn, whose love and devotion is far greater than I deserve. 


\section{TABLE OF CONTENTS}

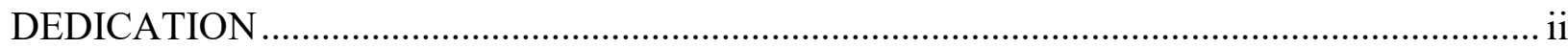

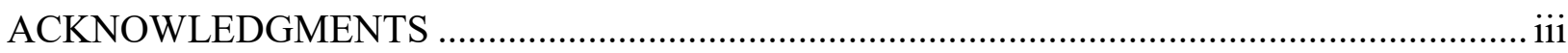

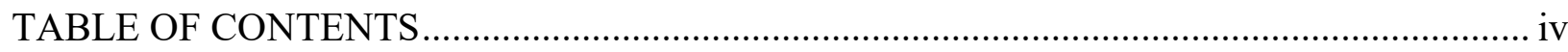

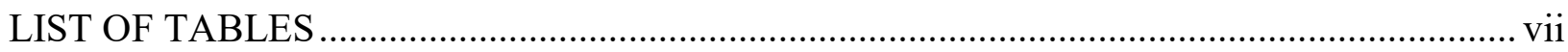

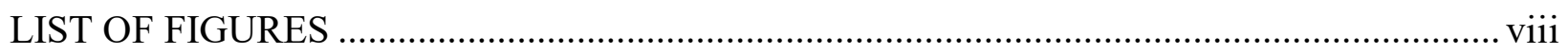

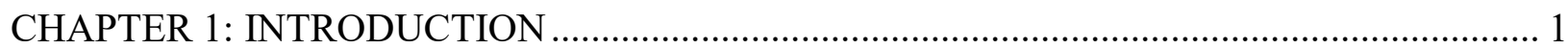

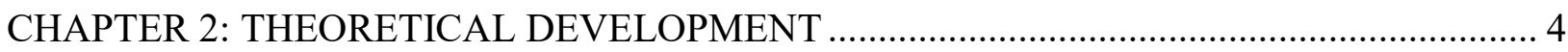

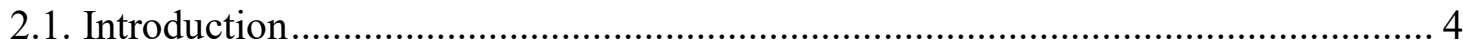

2.2. The Current Approach to CPA ………………………………………………... 7

2.3. Problems with the Current Approach ................................................................. 10

2.4. Describing the Political Landscape....................................................................... 15

2.4.1. Why Would Businesses Engage in CPA?................................................... 15

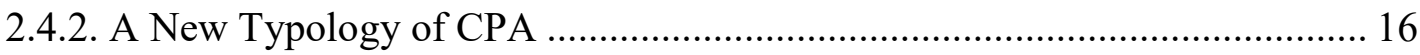

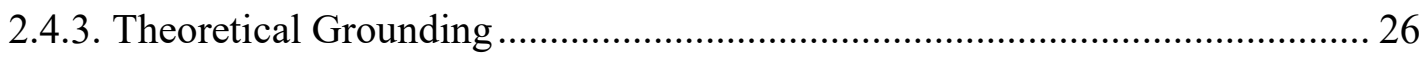

2.4.4. Understanding the Impact of Political Parties on CPA................................... 30

2.4.5. Transactional Versus Relational Approach to CPA........................................... 33

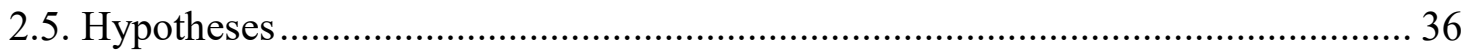

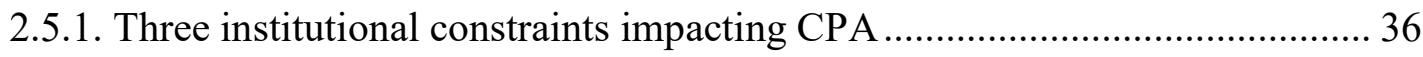

2.5.2. The Impact of Political Parties on CPA........................................................... 41

2.5.3. Effective CPA Targets Undecided Policy Suppliers ...................................... 43

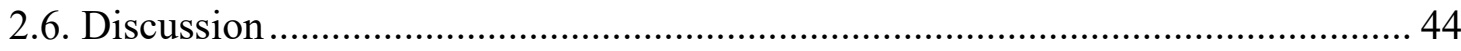

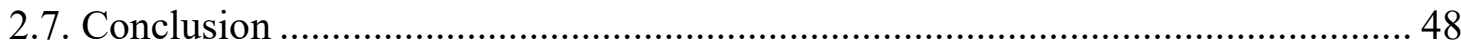




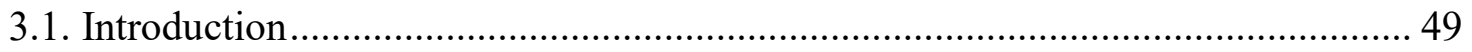

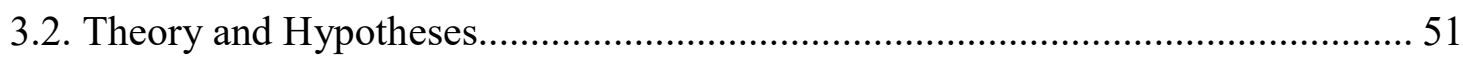

3.2.1. Agency Theory and Stewardship Theory …............................................ 51

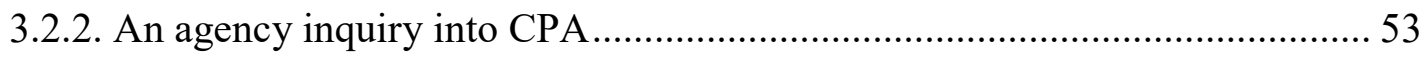

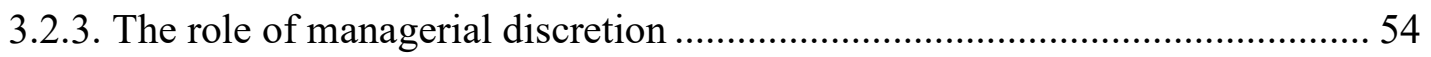

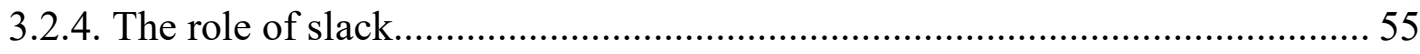

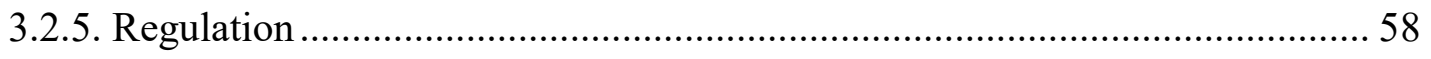

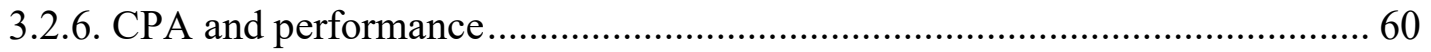

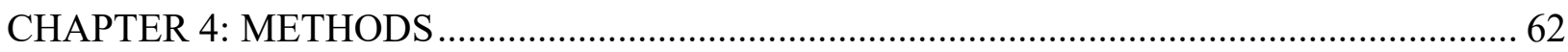

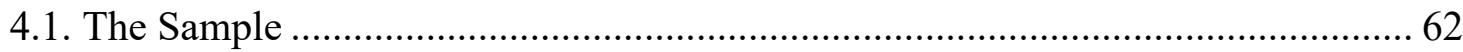

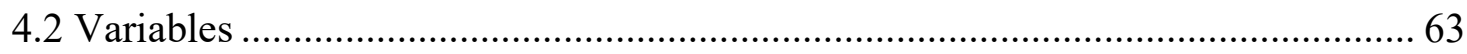

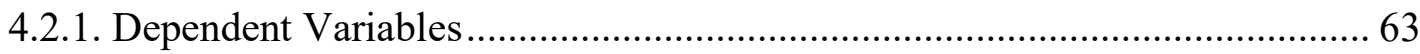

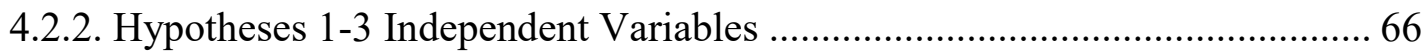

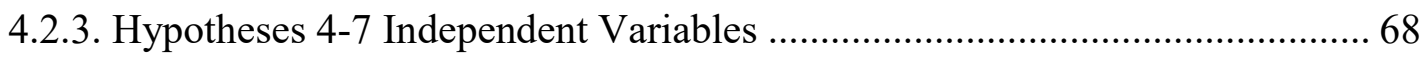

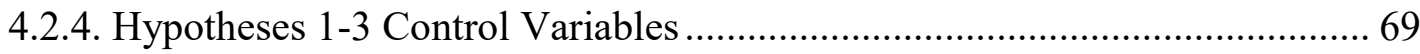

4.2.5. Hypotheses 4-8 Control Variables ...................................................... 70

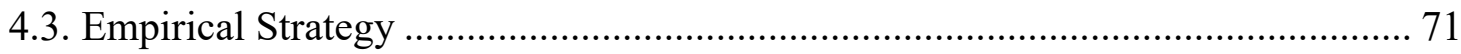

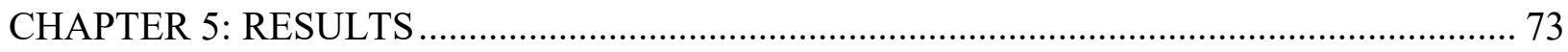

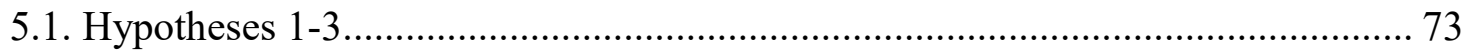

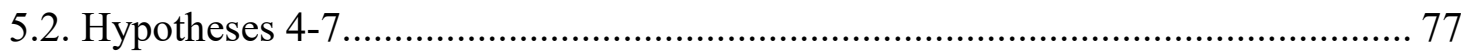

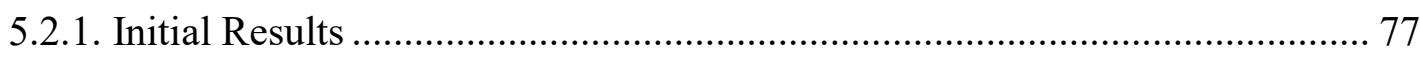

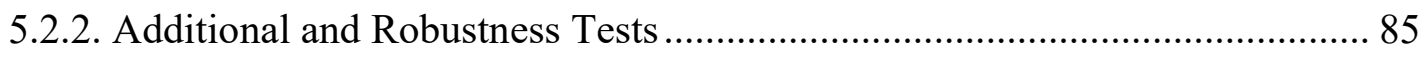




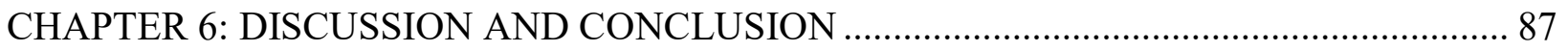

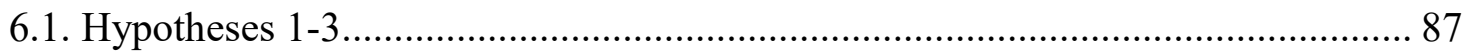

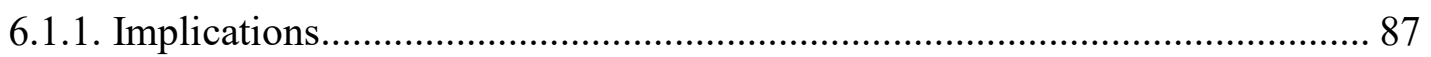

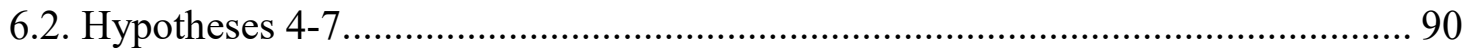

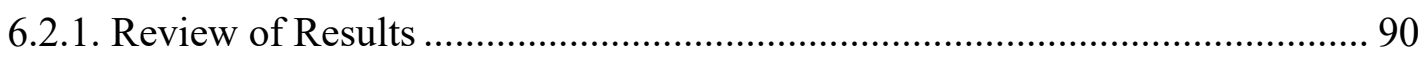

6.2.2. Limitations of This Research .............................................................. 93

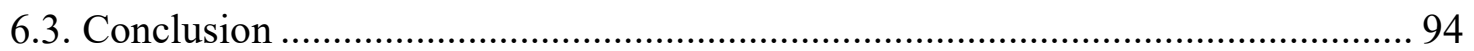

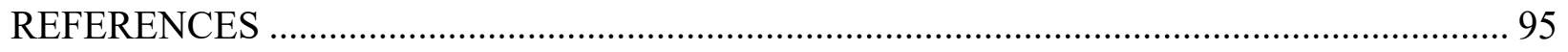

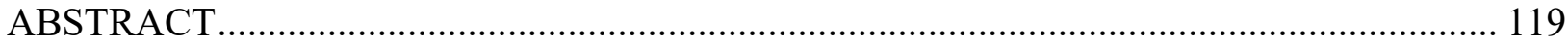

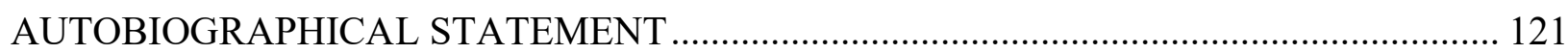




\section{LIST OF TABLES}

Table 1 - Extending the Market Theory ....................................................................... 40

Table 2 - Means, standard deviations, and correlations for Hypothesis 1 and 2 data....... 73

Table 3 - - Means, standard deviations, and correlations for Hypothesis 3 data ............. 74

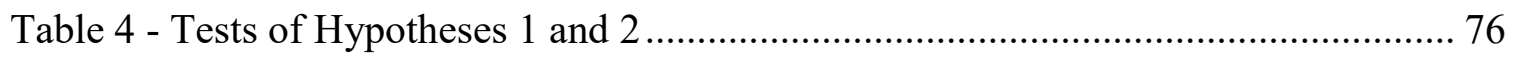

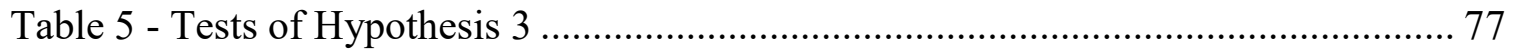

Table 6 - Descriptive Statistics and Pairwise Correlations ......................................... 79

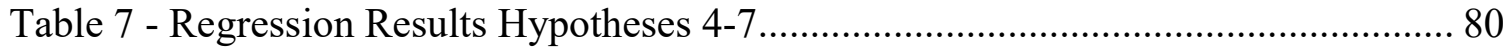




\section{LIST OF FIGURES}

Figure 1 - The Political Landscape Model..................................................................... 19

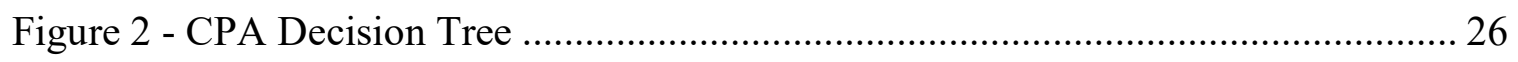

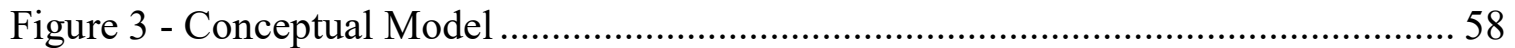

Figure 4 - Moderation Effect of Industry Regulation .............................................. 84

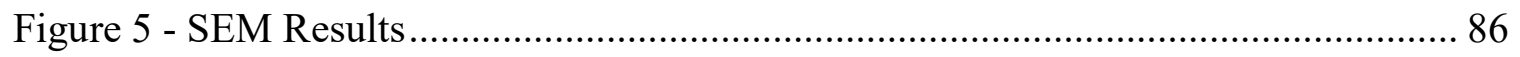




\section{CHAPTER 1: INTRODUCTION}

Corporate Political Activity (CPA), defined as "policies, processes and practices that are intended to influence governmental policy or process," (den Hond, Rehbein, de Bakker, \& Lankveld, 2014: 796) is an area that has generated some considerable interest in the management literature (Hillman, Keim, \& Schuler, 2004). The recent U.S. Supreme Court decision Citizens United v. FEC has made the study of this field all the more important (Bebchuk \& Jackson, 2010; Hansen, Rocca, \& Ortiz, 2015; Stratmann \& Verret, 2015). That decision allowed managers to spend unlimited sums of corporate funds on political activities (Stratmann \& Verret, 2015). Restrictions in American law severely limit the ability of shareholders to control these activities by managers, leading to the potential for abuse (Bebchuk \& Jackson, 2010). That said, CPA can also provide an impressive return on investment for some firms (Bonardi, Holburn, \& Bergh, 2006; Hadani \& Schuler, 2013; Schuler, 1996; Shaffer, 1995). The question for shareholders and scholars, then, is how to achieve these returns.

Thus far, researchers have been largely unable to answer that question. Efforts to show a relationship between CPA and performance have been largely unsuccessful (Hadani \& Schuler, 2013). Furthermore, scholars have proposed a theory to explain CPA, treating it as a market in which demanders of policy, which include businesses, exchange value for policy consideration from suppliers, such as elected officials and regulators (Bonardi, Hillman, \& Keim, 2005). This approach suffers from a number of theoretical problems, including the high potential for market failure due to the inability to enforce agreements, and its empirical support has been mixed (Bonardi et al., 2006). Similarly, in the political science literature, scholars have adopted a theory that looks at how interest groups can exert influence on political players that seems out of proportion to the groups' size (Hansen, Mitchell, \& Drope, 2005; Hart, 2004). This theory too has 
suffered from a lack of empirical support (Hansen et al., 2005). The upshot of this research has been an inability for scholars of either discipline to determine why firms engage in CPA (Hadani \& Schuler, 2013; Hansen et al., 2005).

In response to this muddle, I propose a new theory called "The Political Landscape." In essence, I propose certain constraints that govern the relationships between politicians and businesses. As with legitimacy from institutional theory (Suchman, 1995), these constraints limit the potential actions of parties, while also being subject to modification by these actors. I point to three such constraints: the politicians' ideology, their relationships with supporters, and the political trends of their constituencies. Following resource dependency theory (Casciaro \& Piskorski, 2005), I envision a struggle in which both sides seek to enhance their power relative to the other party by both responding to and impacting these constraints (see also Suchman, 1995; Wry, Cobb, \& Aldrich, 2013). This theory forms the basis of the first part of my proposed dissertation.

The next section of my dissertation involves an empirical test in which I find strong support for many of the arguments I advance, with one major exception. Where I predicted that businesses seeking to build support among policymakers for their favored positions would do so by appealing primarily to undecided politicians, it appears instead that most CPA efforts are instead aimed at the two extreme positions. In effect, businesses appear to be rewarding their supporters and punishing their enemies rather than seeking to add to their supporters from the ranks of the undecided. This result appears consistent with the partisanship that has come to characterize politics over the past few decades.

The final empirical research delves into this insight more deeply. I argue that agency theory might help explain this unexpected result. Relying upon stewardship theory (Davis, Schoorman, 
\& Donaldson, 1997), I suggest that there exist two kinds of business practitioners who engage in CPA. On the one hand are those who seek to influence policy with the aim of helping their business and ultimately improving shareholder return. On the other hand are the top managers who view their access to the shareholders' resources as an opportunity to use these assets to pursue a personal political agenda. My empirical tests support this theory, and find that the best performing firms tend to build support among the undecided politicians, thus engaging in a stewardship approach rather than an opportunistic one, as agency theory suggests (Davis et al., 1997; Eisenhardt, 1989).

This work contributes to CPA research in at least three ways. First, it proposes a new theory and typology that help explain activities that heretofore puzzled scholars (Hillman et al., 2004). For example, the idea that there could be such a thing as "regulatory capture" in which firms essentially come to dominate their government regulators (Admati \& Hellwig, 2013; Hart, 2004) was not well understood under prior theory (Holburn \& Bergh, 2008). Second, it helps explain a conundrum limiting CPA research up until now, namely scholars' inability to find a link between CPA and performance (Hadani, Dahan, \& Doh, 2015; Hadani \& Schuler, 2013). By taking into consideration the interaction between CPA involvement and agency, I demonstrate the differing motivations that might lead executives to CPA activity. Third, in a contribution to agency theory, I show that the problem of opportunism is not limited to financial issues. Instead, executives may engage in their own political agenda even if it runs counter to the interests of shareholders (Bebchuk \& Jackson, 2010; Hadani, 2012). 


\section{CHAPTER 2: THEORETICAL DEVELOPMENT}

\subsection{Introduction}

Nonmarket strategies are an important area of research within the management sciences (Baron, 1995; Shaffer \& Hillman, 2000). Defined as "coordinated actions that firms undertake in public policy arenas" (Bonardi et al., 2006: 1209), the field of non-market strategies has as an important component corporate political activity (CPA) (den Hond et al., 2014). Despite the fact that it is often hard to measure non-market performance (Stevens, Kevin Steensma, Harrison, \& Cochran, 2005), the impact of CPA, defined as a firm's "policies, processes and practices that are intended to influence governmental policy or process" (den Hond et al., 2014: 796), is broadly acknowledged. For example, Frynas, Mellahi, and Pigman (2006) found that CPA strategies can lead to first mover advantages in developing countries. Hadani and Schuler (2013) found that CPA efforts can measurably increase financial performance for firms engaged in highly regulated industries. Similarly, scholars have detailed how CPA efforts can help in resolving trade disputes (Lindeque \& McGuire, 2010; Schuler, 1996). As a result, there have been calls for increased empirical study in the field (Bonardi et al., 2006; Hillman et al., 2004; Pearce, Castro, \& Guillén, 2008; Shaffer, 1995).

In an effort to explain the mechanics of CPA, a number of scholars have developed a market-based theory of the public policy process (Bonardi et al., 2006; Schuler, Rehbein, \& Cramer, 2002). According to this approach, the political process is made up of demanders and suppliers of public policy. The demanders are the businesses involved in CPA, as well as other interest groups, such as labor unions or environmental advocacies. The suppliers are the politicians who hold public office. The theory suggests that in exchange for consideration of their policy position, demanders offer suppliers three forms of currency: information, support, and money. 
Thus scholars use a market-based approach to help understand CPA, despite its nature as a nonmarket activity.

Unfortunately, this theoretical framework will lead to some debatable conclusions. For example, at least two of the three currencies are of questionable value as media of exchange. Given the ready availability of information to officials, information in and of itself has limited value to politicians. Furthermore, while it is true that elected officials must spend much of their time raising money for their election campaigns, a theory that views money as a currency of exchange oversimplifies the relationship. In most cases, the financial contributions will go either to candidates who agree with the position of the public policy demander or to those viewed as persuadable. As a result, business interests and others will not generally contribute to candidates who vehemently disagree with them. Therefore, it is not the contribution, in and of itself, that causes the politician to take a policy position. Instead, there must be certain preexisting characteristics of the politician that make him or her appealing to the business.

The above analysis reveals two problems with the market approach. First, CPA does not occur within a market environment. In fact, in the United States and most other developed democracies, efforts to explicitly bargain an exchange of anything for a public policy position are illegal (Gaioni, 2012). Therefore, at best, this is a market riddled with inefficiency and subject to opportunism (Bonardi, 2011). Second, elected officials are not blank slates. Because of the fact that they almost certainly have been involved in politics prior to their election to office, they already have taken certain policy positions. Similarly, since they are continually concerned about re-election, they will be keenly interested in the views of the voters in their district. An elected official out of step with his or her constituency will not stay in office long. Finally, elected officials must build up relationships over long periods of time. These relationships will be with the 
supporters who, over time, have been the ones to provide funding and grassroots support to the candidate. It is these prior policy positions, existing relationships, and voter concerns that will primarily govern the actions of an elected official. While it is true that underlying these relationships may be an understanding that implies some form of exchange, a more refined understanding of CPA is needed in which such understandings are placed within the context in which CPA takes place. Indeed, Bonardi (2011) argued that future theoretical work on CPA should be based upon a strong understanding of how political environments work. That is what I aim to do with this research.

In this study, I propose an extension of the political market theory that takes these complex factors into consideration. Certainly, money, information and constituent organizing do play a role in the political process, and they can have an important impact on the policy process. Nevertheless, I argue that these factors do not fully address the realities of modern politics and policy advocacy. Instead, I suggest that successful actors in the political process will be aware of the three factors that constitute what I call the politicians' political landscape on a given issue of interest - the politicians' ideology, relationships and political trends in their constituencies -- and use that information as the basis for advocating their interests.

This model more fully explains the various dynamics that occur within the political arena. In so doing, I contribute to the literature in three ways. First, I develop a typology of approaches that businesses and other policy demanders can manipulate in their CPA. Second, I develop a decision-tree detailing the process businesses must go through to determine their options in addressing government action. Finally, in looking to the concept of legitimacy to assist me in my analysis, I demonstrate how institutional theory might become a basis for understanding other nonmarket strategies. 


\subsection{The Current Approach to CPA}

Hillman and Hitt (1999) and Bonardi, Hillman, and Keim (2005) are conceptual studies that have become the basis for much of the subsequent work in the field. The Hillman and Hitt (1999) article is particularly important because it creates a taxonomy for CPA as well as proposing a decision tree to guide firms with the process of becoming politically active. From subsequent articles, it appears that the greatest impact comes from their taxonomy (see e.g. Hillman et al., 2004; Holburn \& Vanden Bergh, 2008). In essence, they proposed three strategies: an information strategy, a financial incentive strategy, and a constituency-building strategy. Each strategy then is divided into a series of tactics. An information strategy includes lobbying and testifying as an expert witness, for example. A financial incentive strategy includes contributions to politicians or the party. Lastly, a constituency-building strategy includes grassroots mobilization of employees and other stakeholders, advocacy advertising, and public relations. To make this taxonomy work, the authors rely upon earlier work that describes the political process as a marketplace that includes suppliers and demanders (Shaffer, 1995). The suppliers are the elected officials and appointed or elected regulators; the demanders are the businesses and other interest groups. The currency of this marketplace includes information, money, and support. The demanders supply the providers with one of the three currencies effectively in exchange for influence on a public policy issue. This market, however, is riddled with inefficiencies, and given the fact that there can be no explicit bargain or enforceable contract, opportunism is a major problem (Bonardi et al., 2006). This is where the Bonardi et al. (2005) paper comes in.

Bonardi et al. (2005) apply Porter's Five Forces analysis to political markets to explain why firms engage in CPA. They point out that firms more dependent on government regulation or contracts, large firms, and those operating in more highly concentrated industries are the most 
likely to invest in such activity. They posit, however, that firms need to look at a political market to determine whether that specific market is more or less competitive and thus more or less attractive, just as Porter did for sustained competitive advantage. In contrast to Porter's forces, however, the proposed CPA forces are the level of competitiveness among the demanders of public policy, the level of competitiveness among the suppliers, the nature of the cost-benefit analysis of the issue, whether the firm is defending the status quo or proposing change, and the level of partisanship over the issue. The demand side includes the various interest groups competing for their policy preferences such as the corporate actors. On the supply side are those in government who make the policy decisions, and they seek the currency of exchange from the demanders: information, votes, and financial support. Most voters are rationally ignorant, since they have neither the time nor the inclination to develop a position on most issues. As a result, most issues are non-election issues, and are not salient to large groups of voters. Since large groups of voters tend to be ignorant about the issue, the business will have few if any opponents for the supplier's support. Thus, a political issue that is not an election issue and has low salience with most voters will be an element of an attractive political market. Similarly, if there is high rivalry among suppliers of public policy, these elected officials will be keener to obtain the support of the firm. Thus, a market with high rivalry among suppliers is actually a more attractive market for CPA. In this way, the firm can look at the impact of the five forces on the specific political market and decide whether the firm should enter that market, wait for it to become more attractive, or avoid it entirely (Bonardi et al., 2005). The driving force behind that decision will be where the firm can most efficiently impact the process.

The influence of this market approach to CPA has been significant, and even research in political science and economics has essentially adopted it. For example, Lubell, Feiock, and de la 
Cruz (2009) adopted the market approach to explain how local governments make decisions on zoning issues. In that article, the demanders of public policy are the developers seeking approvals for their projects. Interestingly, that article takes institutions into consideration, but the institutions considered are the actual structure of the local government (Lubell et al., 2009). Similarly, one of the defining theories in the field suggests that businesses and other interest groups take a transactional view of government relations, engaging in CPA when they can see sufficient benefit from the public goods they receive in return (Hansen et al., 2005; Hart, 2004; Hojnacki, Kimball, Baumgartner, Berry, \& Leech, 2012). Unfortunately, this theory has received poor empirical support (Hansen et al., 2005), leading some to call for an expanded theory (Hojnacki et al., 2012). Thus, this research has application in the political science field as well.

Scholars have struggled with developing an overarching theory of CPA that resolves these and other concerns (Getz, 2001). For example, Bonardi (2011) pointed out that the resource-based view might not be helpful in analyzing CPA due to the fact that most resources available to businesses so engaged are neither inimitable nor non-substitutable. Similarly, Kingsley et al., (2012) suggested that the driving force behind CPA is efficiency. Firms and government actors are parties to a transaction - albeit an imperfect one - attempting to minimize their transaction costs. Even Bonardi et al. (2005), whose approach is to look at how businesses can influence public opinion and thus government policy, do not suggest the existence of institutions that shape and constrain the CPA process. In this way, the current theory seems much like the management theory of the 1970s (Hoskisson, Wan, Yiu, \& Hitt, 1999), before the ideas of the Behavioral Theory of the Firm (Gavetti, Greve, Levinthal, \& Ocasio, 2012), Resource Dependence (Wry et al., 2013), and Institutional theory (Bruton, Fried, \& Manigart, 2005) came to prominence. These theories argued that the driving force behind change in organizations is not efficiency, but power, whether 
it be exerted by those who have control over resources or whether it result from cultural pressures (Scott, 2004). Although some scholars fought the transition away from the earlier, more simplistic construct (Strauss \& Hanson, 1997), in general most scholars have appreciated the greater nuance and improved predictive power of these newer theories (Barley \& Tolbert, 1997). I believe it is time for CPA theory to take a similar step up in sophistication.

\subsection{Problems with the Current Approach}

The political market theory appears to insufficiently addresses at least three realities of modern politics. First is the importance of applying pressure to achieve political ends. The political market theory seems to treat most interactions between businesses and politicians as though the politicians have all the power (Lester, Hillman, Zardkoohi, \& Cannella, 2008). In fact, businesses have significant power which they activate by applying pressure upon politicians who do not respond to more amicable approaches. This reality is demonstrated by the rising importance of issue advertising. These ads, produced and paid for independently of the candidate's campaign, sometimes support a candidate's position but more often attack the opponent's position (Bebchuk \& Jackson, 2010). Such independent issue ads must be effective, or they would not have become so common. Indeed, over the past few years, interest groups have spent more money on such issue advertising than on lobbying, much of it aimed at attacking politicians who disagree with the advertiser rather than rewarding its supporters (Quinn \& Young, 2015) Advertising sponsored by

business interests to attack incumbent politicians opposed to their position does not fit into one of the strategies described in the political market theory. Yet this strategy has become an important tool in the CPA arsenal due to its value in applying pressure to politicians. Thus, the theory needs to be expanded to explain this activity.

Second, the political market theory posits information as one of the currencies demanders 
of public policy can exchange with suppliers. While information is of value to politicians, they have no difficulty obtaining it (Schuler et al., 2002). According to OpenSecrets.org, there were 11, 243 active registered lobbyists in Washington in 2016 (The Center for Responsive Politics, 2017). Contrast that number with the 535 members of Congress, and one can see that there are over twenty lobbyists for each elected official. Such a volume of information sources means that the challenge facing elected officials is not in obtaining information in the first place, but in choosing which information to prioritize (Rerup, 2009). Indeed, in their seminal political science article, Hall and Deardorff (2006) argued that the primary role of lobbyists was not to persuade elected officials of their clients' position, but to simply develop relationships with legislators that enable them to assist the officials in determining which information to prioritize. The political market theorists would argue that the financial contributions or other political support the demanders provide will entice the supplier to value their information more highly than other information. Such logic, however, reveals that the information, in and of itself, is not a valuable currency. Thus, one of the three main strategies suggested by this theory has limited value.

Third, the political market theory does not account for the importance of ideology in political decision-making. Ideology in a political context has been defined as "worldviews which include preferences regarding social outcomes, and theories about how those outcomes can be obtained" (Simons \& Ingram, 2004: 33). Both the demanders and the suppliers have preexisting political views that impact their responsiveness to certain arguments. Evidence of such preexisting views abounds. For example, research has found that while corporate campaign contributions go to candidates in both political parties, the contributions by the top managers skew toward Republicans (Hillman et al., 2004). If the top managers were simply acting in their financial interest when they made contributions, their personal contributions should match those of their 
firm. Instead, this disjunction demonstrates that while the managers make sure the firm's contributions benefit the shareholders as their duty dictates, when it comes to the managers' own personal money, they contribute based upon a different analysis. Similarly, cigarette manufacturer Philip Morris is the largest provider of business campaign contributions in the United States (Schuler et al., 2002). Despite its munificence, however, a committed anti-smoking advocate serving in office would be unlikely to respond to entreaties from this firm. No amount of campaign contributions or political support will change that fact.

The problem the political market theory has explaining the impact of ideology and prior prejudices goes even further. For example, scholars have shown that businesses have a particularly difficult time fighting the opposition of ideologically driven interest groups (Bonardi et al., 2006). Furthermore, the theory assumes that the voters are a blank canvas (Bonardi et al., 2005). Voters, however, already have certain experiences, perceptions, and prejudices that will inform their opinions on issues. That is why the railroad industry was able to impact public opinion against multitrailer trucks with ads showing large rigs in the rearview mirror of a family car (Weisensee, 1991); or why with so many people knowing a gay person, public opinion on same sex marriage has changed so rapidly (Coontz, 2014). The impact of these ideological factors is not explained by the political market theory.

The literature based upon the political market theory has tried to address these deficiencies in a number of ways, including referencing how high competitiveness among policy demanders in a political marketplace will limit a politician's options; how certain issues become election issues that are salient with the voters while others do not (Bonardi et al., 2005); and how business interests sometimes need to negotiate difficult interactions between legislators, the executive, and regulators (Schuler et al., 2002), to name a few. These examples point to the fact that this theory is ripe for 
extension.

As systems theory makes clear, organizations operate as partially open systems impacted by the environment (Karniouchina, Carson, Short, \& Ketchen, 2013; Kast \& Rosenzweig, 1972; Scott, 2004). Implicitly, the market theory of CPA recognizes this fact, since firms engage in the political process to access resources they need, establish legitimacy, and otherwise respond to important environmental inputs (Boyd, 1990; Casciaro \& Piskorski, 2005; Julian, Ofori-Dankwa, \& Justis, 2008; Meznar \& Nigh, 1995; Oliver, 1991; Scott, 2004; Wry et al., 2013). However, as Casciaro and Piskorski (2005) pointed out, there are two sides to any such arrangement. Thus, on the one hand, the market theory recognizes the fact that the policy demanders must engage with their environment. However, it fails to recognize that the policy suppliers must engage with their environment as well. These environmental constraints upon the CPA interaction can be characterized as internal and external. The internal constraint is the policy suppliers' ideology, defined as "worldviews which include preferences regarding social outcomes, and theories about how those outcomes can be obtained" (Simons \& Ingram, 2004: 33). As Holburn and Bergh (2008) pointed out, the ideology of the suppliers will impact their policy position, and a policy demander should develop a CPA strategy taking the suppliers' ideology into consideration. Indeed, ideology is why many policy suppliers became involved in the political process in the first place (Thomsen, 2014). As a result, an overarching theory of CPA that does not recognize the impact of the policy suppliers' ideology on their actions will be incomplete.

Similarly, there is an external environmental constraint that will impact the policy positions of the supplier. Political forces have been divided into those that have achieved saliency and those that have not (Bonardi \& Keim, 2005). When an issue is salient, it has engendered enough political support in the community that it can impact the election (Bonardi \& Keim, 2005; Nigam \& Ocasio, 
2010). Since the primary goal of most elected officials is reelection or election to a higher office (Maestas, Fulton, Maisel, \& Stone, 2006), elected officials will be loath to take a position contrary to a salient issue (see also Bonardi \& Keim, 2005). It is worth noting that issue salience may differ from location to location (Maestas et al., 2006; Simons \& Ingram, 2004; Thomsen, 2014). Thus an issue that has achieved salience in one political district might not have the same importance in another (Palazzolo \& Moscardelli, 2006). For example, farm issues may be very important in states such as Iowa or Nebraska that are very rural and whose economies depend upon agriculture, while such issues may have limited impact in more heavily urbanized states such as Massachusetts or Florida. As a result, for each issue, a policy demander will have to determine whether each supplier is constrained by the potential saliency of a political issue in his or her district.

Political trends that result in salient issues also constrain appointed officials as well as elected ones, just less directly. Appointed regulators have constituencies just as do elected ones: they are the elected officials who can reappoint the regulators, determine their budget and their legal mandate (Bonardi et al., 2006; Holburn \& Bergh, 2008). While it is true that elected regulators tend to be more responsive to consumer demands than do appointed ones (Holburn \& Bergh, 2008), a regulator who takes positions completely at odds with the positions demanded by the elected official's electorate is unlikely to be reappointed (Laffont \& Tirole, 1991; Levine \& Forrence, 1990). Just as the elected officials' own positions can be held against them, so too can the positions taken by officials they appoint or oversee. As a result, appointed officials need to be aware of the political trends that might result in issues becoming salient for the elected officials who appoint and oversee them. 


\subsection{Describing the Political Landscape}

\subsubsection{Why Would Businesses Engage in CPA?}

Businesses do engage in CPA (Hillman et al., 2004; McDonnell \& Werner, 2016), begging the question of why would they. Indeed, research aimed at finding a relationship between investment in CPA and firm performance has been inconclusive at best (Aggarwal, Rajesh, Felix, \& Tracy Yue, 2012; Cooper, Gulen, \& Ovtchinnikov, 2010; Hadani et al., 2015; Hadani \& Schuler, 2013). To explain this apparent paradox, I subdivide firms engaging in CPA into two groups, one where the firms are impacted by government activity, the other where executives take advantage of the resources at their disposal to pursue their own personal political agendas. I will explain the activity of each group with a different theory.

The first group, where their business is impacted at some level by government activity, will be a much larger group than some might suspect (Porter, 1980). Firms falling within this category would be those who face government regulation of some kind (Hadani \& Schuler, 2013; Hansen \& Mitchell, 2000; Holburn \& Vanden Bergh, 2008; Shaffer, 1995), those for whom the government is a significant purchaser of their products and services (Hillman et al., 2004; Porter, 1980), or those directly impacted by government policy, such as trade policy, for example (Lindeque \& McGuire, 2010; Schuler, 1996). For this category of businesses, resource dependence theory helps explain the firms' reasoning (Casciaro \& Piskorski, 2005; Pfeffer \& Salancik, 2003; Wry et al., 2013). In essence, these firms will be heavily dependent upon resources controlled by the politicians, and similarly, politicians will be heavily dependent upon resources the businesses can provide them, such as campaign funding or constituency support (Dess \& Beard, 1984; Oliver, 1991; Pajunen, 2006). This mutual dependency will create an equilibrium prompting each party to assist the other (Marquis \& Qian, 2014). In such cases, however, the parties will attempt to disrupt 
this equilibrium, thus giving them more power over the other party (Boyd, 1990; Casciaro \& Piskorski, 2005; Green \& Welsh, 1988; Mahoney, McGahan, \& Pitelis, 2009). Businesses engaging in activities to change the dynamic such that they have more power over the politicians rather than vice versa is the essence of CPA.

On the other hand, there will be a group of firms investing in CPA who do not rely so heavily on government input, and in those cases, agency theory will assist in understanding their reasoning (Hadani et al., 2015). Where executives might have resources at their disposal and the discretion to use them, these executives might engage in CPA to support their own political agenda (Hadani, 2012). Unfortunately, under American law, the ability of shareholders to restrict such activities is severely limited (Bebchuk \& Jackson, 2010). The end result will be top executives engaging in CPA for their own ideological purposes rather than for reasons that benefit the firm. In these cases, the executives will use the same CPA tools aimed at shifting power to them rather than the politicians, but with the goal of forwarding their own political agenda rather than increasing shareholder value. I believe both kinds of firms exist and engage in CPA, and the activities they use to achieve their goal of gaining power over the politicians is the subject of the balance of this chapter.

\subsubsection{A New Typology of CPA}

I propose an extension of current CPA theory in which I build upon Hillman and Hitt (1999) to add nuance to their typology of political activities. Under the Political Landscape model that I propose here, the politicians, including legislators, regulators, and other public officials, must negotiate a challenging terrain. In crossing this landscape, the politicians will consider various topographical features that create barriers to their passage. These topological features are based upon the motivation of the politicians, and they include the ideology of the politician, the political 
trends in the politician's constituency, and the pre-existing relationships the politician has. The political market theory focuses on currency that the demanders of public policy, such as businesses, can give to the politicians in an effort to gain their support. Thus, the political market theory takes into consideration the need for corporate actors to appeal to what motivates political actors - essentially their interest in retaining office and expanding their power (Bonardi et al., 2006; Schuler et al., 2002). However, the political market theory does not take into consideration the impact of ideology on the process, something that has a central impact on American electoral politics (Thomsen, 2014). Research has shown that by far the most important motivating factor that induces a candidate to run for office is an ideological interest in one or a set of political issues (Baer \& Hartmann, 2014).

Once they decide to run for office, candidates need to build support, which they accomplish by establishing relationships with individuals and organizations that can provide them with money and grassroots support (Schuler et al., 2002). It has been shown that the amount of campaign contributions are correlated with the amount of time a candidate spends with the donor (Schuler et al., 2002: 5). Furthermore, the second most important motivator for a candidate to run for office is his or her family, friends, and other relationships (Baer \& Hartmann, 2014). In this way, these relationships become a central part of the policy politician's support system, and they cannot be ignored by demanders seeking to influence the public official (Peress, 2013).

Finally, elected officials cannot ignore policy issues that gain the attention of the broader constituency. When an issue gains saliency, it goes from being ignored by a public overwhelmed with their own concerns to an issue of electoral importance (Bonardi et al., 2005). Once such issues gain the public's attention, corporate actors will likely be unable to influence the direction of the issue (Bonardi et al., 2005). Elected officials can influence their constituencies, but such efforts 
will deplete political capital that they could otherwise use for another issue perhaps dearer to their heart or for their own re-election (Matsubayashi, 2013). Thus elected officials will be loath to take steps that alienate their constituencies, even despite the requests of a corporate supporter.

As a result, each time a business has an issue of concern, it must analyze for each politician the nature of his or her ideology, the political trends in the politician's constituency, and the politician's relationships. In each case, the business will have to ask itself whether each feature in the political landscape will make the politician more or less receptive to the requests of the business, and whether the business is able to impact any of these features. Thus the businesses have a two-way relationship with these features: they must determine if the features make the politician more or less likely to be responsive, and simultaneously, whether the business can impact that feature. In this way, the business could formulate a strategy to achieve the public policy outcome it seeks. 
Figure 1 - The Political Landscape Model

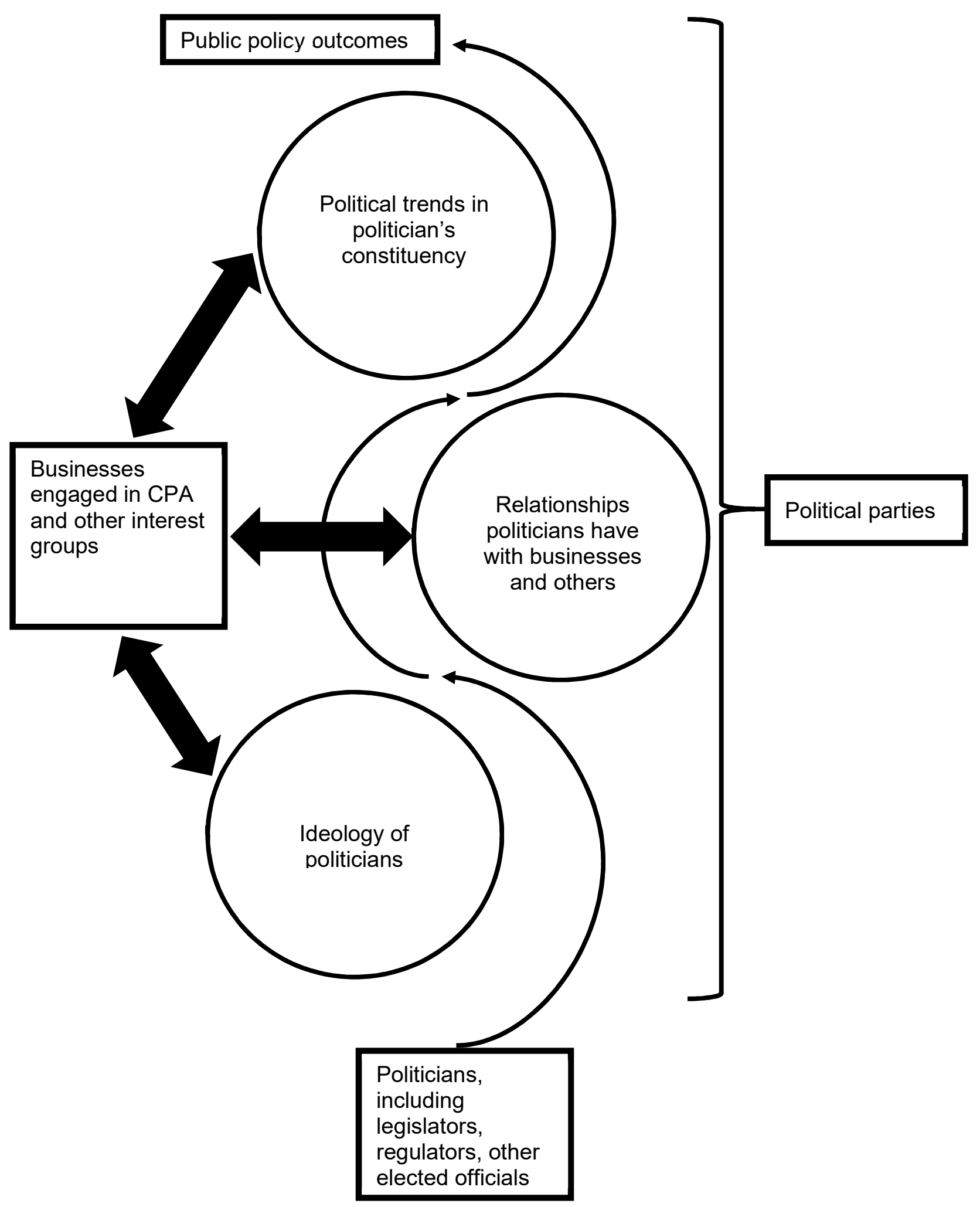


The starting point for this analysis is certainly the politician's ideology. If the politician is by nature hostile to the business's policy position, the business will only waste time and money courting that official. Fortunately, in most cases, the public official will be quite open about his or her position on the issue. There may already be a public record reflecting that position. As a result, research on this question is typically not difficult. I expect there to be an inverse U-shaped relationship regarding the responsiveness of the politician to the business. On the one hand, if the politician is set against the business's position, as with, for example, a cigarette maker approaching an anti-smoking advocate, the business need not attempt to influence that official. On the other hand, if the politician is in fact predisposed to the position of the business, there is no need to influence that politician. In fact, that politician may have the potential for becoming an ally of the business in achieving its public policy outcome. The bulk of the businesses' attention, however, should be directed at those politicians who have no position on the issue because of either lack of knowledge or lack of interest. Ironically, it is those public officials who will become the initial targets of the business's efforts.

Once the firm has determined the extent to which the politician's ideology will leave him or her open to the business's requests, the business must determine its ability to influence the politician. Here is where the information strategy pointed to in the political markets theory becomes useful. If the business has the politician's initial support, the business only needs to maintain its relationship with the politician in an effort to bolster that position. If the politician is ideologically opposed to the business's position, there is no point in approaching that politician. However, if the politician is uncommitted on the issue for whatever reason, that politician could be open to the business providing information on the issue. In this way, the business could 
influence the politician's views, emphasizing that feature of the political landscape on the issue such that the politician is pushed toward the business's position.

The second step in the business's analysis should be to consider the relationships of the politician. Various means exist to establish a relationship with the politician, including making financial contributions (Hillman \& Hitt, 1999), providing political support within the politician's constituency (Bonardi et al., 2005), hiring former public officials who enjoy a relationship with the business (Lester et al., 2008), or encouraging current employees to take government positions in which they might establish strong relationships with the politicians (Hillman, Zardkoohi, \& Bierman, 1999; Johnson \& Kwak, 2013). Each of these methods has been used to that end. Just as important, however, is determining whom else the politician has relationships with. For example, even if the politician has no firm ideological position on an issue, the politician could be closely allied with a lobbyist, a constituent, or another individual who does. Or, for that matter, the politician might have a strong relationship with a lobbyist or another activist whose support the business can gain. Just like any human being, the politician does not want to disappoint his or her supporters and friends. In this way, just as the business analyzed the status of the politician's ideology and from there determined if a strategy was available to influence that ideology, so too must the business determine if it has a relationship with the politician or if its opponents do, and if not, whether it can establish one. Thus, the business again establishes where the barrier lies on the political landscape, and based upon that analysis determines whether it can impact that feature such that it pushes the politician toward the business's position.

Finally, the business must determine the political trends in the politician's constituency. That analysis, however, requires several steps. First, the business must figure out who exactly the constituency of the politician is. In some cases, that answer might be readily apparent, as with 
elected officials who represent a district. In other cases, the answer might not be so obvious. All politicians have a constituency, just as all businesses have customers. For example, certain regulators are elected. In those cases, their constituency would be their electorate. Certain public officials are appointed. In those cases, the business must ascertain who appoints the public official and whether it be an individual or some kind of board, commission, or legislative body. Even public officials who are not elected and who are not seeking reappointment have constituencies. Regulators, for example, do not want to see their decisions overturned by the governing executive, the legislature, or the courts (Holburn \& Vanden Bergh, 2008). As a result, they are constrained in their actions based upon the views of those parties. In this way, those regulators who may seem at first to act in an unconstrained fashion actually have constituencies who can influence their actions (Holburn \& Vanden Bergh, 2008). Most attractive for business interests are those regulators or officials who view the business as one of their constituents. While much attention has been directed at the concern over "regulatory capture" (Admati \& Hellwig, 2013), in which regulators appear to act on behalf of the industry they regulate, the nature of this relationship can also be less suspect. For example, the business may employ many citizens in the official's district, or have an important facility located there. And in some cases, the regulated parties actually provide some if not all of the funding for the agency (Permanent Subcommittee on Investigations, 2011). Some elected officials might even have multiple constituencies, such as legislative leaders who on the one hand represent a specific district while on the other hand also rely upon the votes of their fellow legislators to maintain their leadership positions. As a result, determining the politician's constituency might be less clear than one might expect.

Once the politician's constituency has been established, the business needs to use that information as a basis to determine whether the public official will be responsive to the business's 
requests or not. Returning to my example of the cigarette manufacturer, while that firm might be unwelcome in the office of a fierce anti-smoking advocate, it would receive a very different reception from a legislator who represents a district with a large number of tobacco farmers. Even if the public official is personally ambivalent on the issue, he or she will likely vote with the interests of the district to assist in re-election. Similarly, representatives from Michigan will not vote against the automakers, nor will officials from Washington State vote against the aviation industry. As a result, the successful advocates for businesses will have a strong sense of the various limitations placed upon the actions of the public official as a result of his or her constituents' interests.

The analysis, however, should not end there. Indeed, this is one feature of the political landscape that may be susceptible to influence by the business. Earlier, I discussed the example of firms engaging in indirect political action aimed at impacting elections (Bebchuk \& Jackson, 2010). Businesses do periodically engage in grassroots lobbying efforts or public relations programs aimed at changing the opinion of the politician's constituents (Bonardi et al., 2005). The two other strategies proposed by the political market theorists, providing money and information, fit squarely within the domain of this barrier. The reason that elected officials are interested in those two strategies is that money and support will assist the politicians in their re-election campaign (Hillman et al., 2004). While it is true that the ultimate goal of the business in providing support and contributions is to establish a favorable relationship with the politician, from the politician's perspective, the value of this assistance is in providing resources for the politician's campaign. Evidence of this fact comes the reality that many corporate political contributions are made in highly contested races. If the goal were simply to buy access, the focus of contributions would primarily be to incumbent politicians sitting in safe seats. The difference is that these 
candidates with a secure position are not asking for contributions because they do not need them. Instead, most campaign contributions go to the candidates with the toughest races simply because those candidates need the money to finance their campaigns. Thus, as with the other two elements to the landscape, businesses might be able to influence this barrier too. Unfortunately, making a significant impact in this area can be very expensive (Kingsley, Vanden Bergh, \& Bonardi, 2012), so this approach works best when combined with efforts to impact the other two elements.

An unfortunate corollary to the above arguments is that there will be issues where the business will be simply unable to achieve its goal given the environment at the time. For example, if it turns out that the factors of the political landscape make it so that sixty out of one hundred U.S. senators are not inclined to support the business's position, the business has two choices. First, it may attempt to change the landscape such that a number of the U.S. senators will be able to move to its position. If the business is unable to accomplish such a change, it will have to take the other option: essentially it will be forced to wait until the political landscape changes such that its position fits better with the political landscape factors of a majority of elected officials. Such an alignment of forces occurred in the wake of the recent financial crisis when Congress passed the Dodd-Frank financial reform bill. Many financial institutions did not favor the proposed reforms, but they found they were unable to impact the debate much due to the broader political trends among taxpayers outraged over the bailouts (Blinder, 2013; Permanent Subcommittee on Investigations, 2011). Thus, the political landscape did not favor the demands of this corporate interest. Such an analysis will be important for firms to conduct prior to expending the time, effort, and resources necessary to mount an effective CPA campaign on any given issue.

A review of existing research provides support for this typology. For example, Hall and Deardorff (2006) argued that the greatest value lobbyists provide to their clients is not their ability 
to convince uncommitted legislators to support a business's policy position, but in the close relationship they develop with certain supportive politicians for whom the lobbyists can help prioritize information. Thus, Hall and Deardorff simultaneously discount the value of information as a currency of exchange while also emphasizing the value of relationships with politicians as being a key element to CPA. Similarly, Bonardi (2011) argues that relationships with politicians might be one of the few resources available to businesses that are valuable, rare and nonsubstitutable, while acknowledging that in the alternative, businesses can hire lobbyists able to provide access to these relationships. Kroszner and Stratmann (1998) found that lobbyists are more likely to financially contribute to legislators with whom they have longer relationships, supporting the conception of financial support as a reflection of the relationship factor, as opposed to a form of exchange in and of itself. Finally, the findings of Lord (2000) provide empirical support for the idea that information is not helpful to CPA efforts, but engagement with the politician and his or her constituencies is.

The analysis described above is mapped out in the decision tree included as Figure 2. 
Figure 2 - CPA Decision Tree

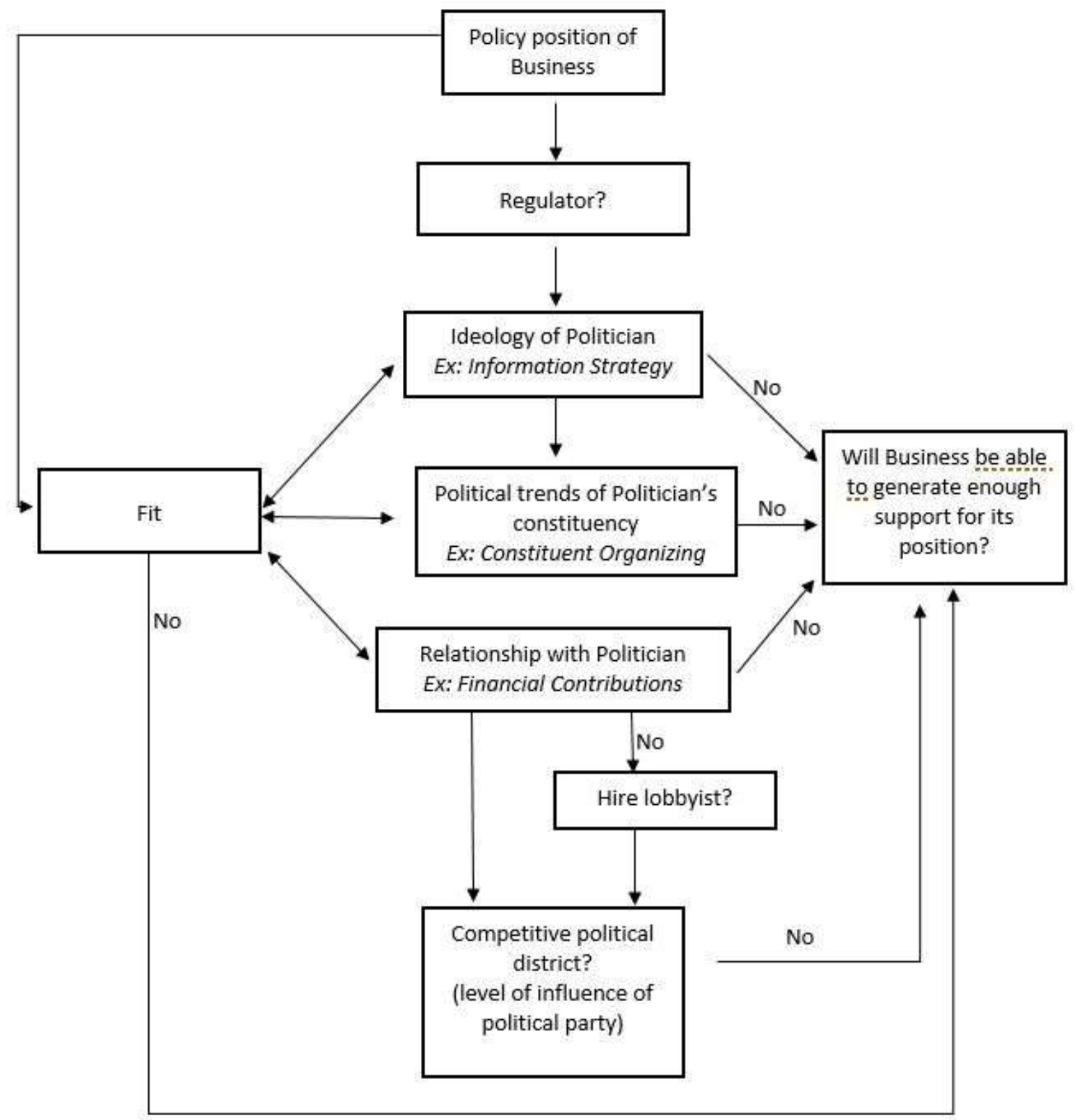

\subsubsection{Theoretical Grounding}

I find support for this typology in the concept of legitimacy from institutional theory as described by Suchman (1995). Institutional theory posits that individuals and organizations operate in an environment characterized by certain beliefs, norms and assumptions that can be referred to 
as "institutions" (Barley \& Tolbert, 1997; Meyer \& Rowan, 1977). Individuals and organizations seek to attain legitimacy by conforming to the demands of these institutions (Aldrich \& Fiol, 1994; DiMaggio \& Powell, 1983; Marquis \& Qian, 2014; Meyer \& Rowan, 1977). Indeed, the more formal structures that many would envision upon hearing the word "institution" are actually simply enactments of the beliefs, norms and assumptions that govern society (Meyer \& Rowan, 1977). While it is true that institutions thus constrain individuals and organizations, people also have the ability to modify institutions over time (Barley \& Tolbert, 1997). This theory explains quite well the realities of CPA discussed above. For instance, using the example of the railroad ads aimed at defeating legislation to allow multitrailer rigs, these ads played upon certain beliefs held by voters, namely that families driving on the highway should be safe. By appealing to that concern, the railroad industry made this issue into one that was salient with the public, thus positively affecting the re-election of the incumbent, and making the politician less open to the entreaties of the trucking industry (Bonardi et al., 2005). This particular case was a strikingly successful example of CPA in action, and it incorporated all the elements of institutional theory; that is, the railroad industry appealed to existing prejudices and beliefs, modified them, and in so doing, created constraints that limit the options of the politicians and competing industries. Consequently, it appears that institutional theory has a strong application in the study of CPA.

Suchman (1995) argues that organizations can achieve three types of legitimacy: pragmatic, moral, and cognitive legitimacy. This typology of legitimacy has achieved widespread acceptance in the literature (Stevens, Xie, \& Peng, 2016). Just as Suchman (1995) argued that there are three forms of legitimacy that can constrain and shape the environment, I argue that there exist three forces that govern the relationships between various political actors. First, pragmatic legitimacy is achieved when an organization convinces a certain public to support its position, thus 
turning that public into a constituency (Suchman, 1995: 578). Similarly, all politicians must be cognizant of maintaining their support among their constituencies. For elected officials, if they fail to maintain such support, they will be defeated in their election; for appointed officials, they will lose the support of their elected superiors, resulting at least in a reduction of resources and authority and at worst a removal from office (see Bonardi et al., 2006). Suchman (1995) argues that such legitimacy can be achieved in three forms. Exchange legitimacy involves convincing publics that an organization will do something specific for the potential constituents in exchange for their support. Such efforts appear strikingly similar to the promises politicians frequently make in an effort to build support (McGraw, Lodge, \& Jones, 2002; Sulkin, 2009). Second, influence legitimacy involves creating an overall perception that an organization is broadly supportive of the public's priorities. Again, this approach echoes politicians' frequent claims that they stand on the side of their constituents and can be expected to fight for their interests. Finally, dispositional legitimacy creates the perception among constituents that the organization is trustworthy and can be counted on to reflect the public's values. The recent presidential election with its extremely personal attacks on both sides points out how valuable the perception that a candidate shares the public's values is to a politician. In each of these cases, the publics will have pre-existing perceptions, some of which might be very hard to change, that will influence the politicians' ability to achieve this form of legitimacy (Blinder, Ford, \& Ivarsflaten, 2013). These pre-existing perceptions, when they achieve a certain saliency with the public, can be referred to as "political trends." Since politicians must maintain this form of legitimacy to be reelected or reappointed, these trends will constrain their actions. As a result, for a policy position supported by a business to receive support from a politician, it must consider overall political trends of that politician's constituency, either acting within those trends or changing them. Thus, the first element of my 
typology of constraints that govern the relationship among political actors is the trends of the politicians' constituencies.

Second, moral legitimacy occurs when an organization has achieved a positive normative perception among its publics, essentially creating a sense of trust for its constituents that it can be counted on to do the right thing (Aldrich \& Fiol, 1994; Suchman, 1995). Achieving such legitimacy can be very difficult, since the slightest perception that the organization is insincere in its moral leadership will undermine its efforts. To attain such legitimacy, organizations will employ individuals called "moral entrepreneurs" to bolster the organizations' claims. Politicians face a particularly difficult challenge in achieving such legitimacy due to the negative perception so many people have of them (Hart, 2004; McGraw et al., 2002). To address this difficulty, politicians will rely upon groups of supporters to act as their ambassadors, signaling to other potential supporters and contributors that the politician is one of strong moral standing (Alt, Lassen, \& Marshall, 2016; Amit, Brander, \& Zott, 1998; den Hond et al., 2014; Foss \& Lindenberg, 2013; Hsu, 2004; Peress, 2013; Sokhey \& McClurg, 2012). Thus, maintenance of these moral ambassadors is essential for politicians. This need will make it very hard for politicians to vote in a way that one of these key ambassadors opposes. As a result, such relationships will constrain the possible actions of politicians, and they thus become the second element of this typology of factors that govern CPA.

Finally, cognitive legitimacy arises due to the fact that we live in a "cognitively chaotic" environment (Baron, 1998; Suchman, 1995). Within such circumstances, individuals will rely upon biases and heuristics, "simplifying strategies that individuals can use to make decisions, especially in uncertain and complex conditions" (Busenitz \& Barney, 1997: 13). One such heuristic that is especially useful in a political environment is ideology, defined earlier as the worldviews 
of the actor (Simons \& Ingram, 2004: 33). Indeed, research has shown the central impact of ideology on American electoral politics (Thomsen, 2014), and it is by far the most important motivating factor that induces a candidate to run for office (Baer \& Hartmann, 2014). As a result, political actors and their constituents will look at the world through the lens of their ideology. It is for this reason that the currency of information is of little value to political actors. In effect, political actors will disregard information that disagrees with their ideology in a process called confirmation bias (Iyengar \& Hahn, 2009). Thus, even if one believes that politicians have the cognitive resources available to pay attention to the information businesses bring to them, then such information will either be privileged or ignored based upon its agreement with the politician's ideology. As a result, more important to the cause of a specific policy position than the delivery of supposedly valuable information would be the level of agreement that information has with the politician's ideology (Holburn \& Vanden Bergh, 2008). In this way, ideology forms a final constraint advocates must consider.

\subsubsection{Understanding the Impact of Political Parties on CPA}

Strategy researchers view institutions as resources that can be extracted from the environment to assist an organization in achieving its goals (Suchman, 1995: 576). A similar view can be taken of politicians who extract resources from the environment to assist them in achieving their political goals, including reelection, reappointment, and the expansion of their influence (Bonardi et al., 2006). Thus, contrary to the political market theory which characterizes the politicians as the ones with all the power that must be essentially purchased by businesses, politicians and businesses engaged in CPA are actually mutually dependent. Politicians need the businesses as a source of the resources that enable them to negotiate the political landscape; similarly, businesses need the policy-making ability of the politicians (Hillman et al., 2004). Given 
the fact that there is mutual dependency and limited resources, it appears that resource dependency theory has an application here (Pfeffer \& Salancik, 2003; Rogan \& Greve, 2015; Wry et al., 2013). Pursuant to resource dependency theory, actors will seek avenues to reduce their dependency and thus shift the balance of power into their favor at the expense of the other party (Casciaro \& Piskorski, 2005; Green \& Welsh, 1988). Thus, in districts where there is no other institutional player who can be an effective supply for the resources the politicians need, they will be extremely dependent upon the support of business interests engaging in CPA. However, in districts where one political party or the other is dominant, the parties themselves can be a source for the politicians, thus reducing the influence of the business community.

Political parties serve as important players in the political process (Williams-Wyche, 2014). As shown in Figure 1, political parties provide an option to politicians who seek an alternative to relying upon the support of business. While from time to time the political party will take a policy position favored by the business, this does not equate a political party with the business. The distinction between the two is clear: businesses engaged in CPA are, by definition, looking for something from the politicians; political parties, however, have as a purpose serving their members, in particular their elected officials. For example, while the Koch brothers may be strong supporters of mostly Republican candidates, and while George Soros may be a strong supporter of mostly Democratic candidates, there will be times that the interests of those individuals may diverge from the interests of the elected officials they support (Alexander, 2014). No matter how closely two individuals may agree philosophically, there will inevitably come issues where the two disagree. There may come an issue where the disagreement is so intense that the business may decide to stop supporting the elected official. The political party, however, will rarely abandon the elected official. There have been times elected officials choose to leave a party. 
Sometimes that departure is based upon a belief that the "party has moved away" from the elected official. There have been elected officials, even high-ranking ones, who have been defeated for reelection in their party primary. In all these cases, however, the party as an institution did not turn on the elected official. The ideology of the party's rank and file may have changed such that the elected official no longer represents the party's mainstream, but ultimately, the party as an institution remains supportive of its elected officials (see Hershey, 2007).

As such, the political parties constitute countervailing forces against the influence of the businesses engaged in CPA. Even when political parties may have strong ideological ties to a business, the role of the party is to enable the elected official to remain independent of the pressures the business is bringing to bear. Much as the corporate interest may look to find candidates ideologically aligned with its position, much as the corporate interest may work to influence the political trends in the politician's constituency, and much as it may seek to establish relationships with important elected officials and regulators, the political party will stand in a position to allow the politician to retain his or her independence. Thus while the corporate interest may push a specific ideological position, the elected official will find refuge from that position in the overarching institution of the party. Similarly, while the businesses may work to establish relationships with the elected officials, the party will provide them with other avenues to find supporters. Finally, while businesses engaged in CPA may attempt various strategies to influence the politician's constituency, the political parties will provide the officials with a base of support to protect themselves from that influence. It is often surprising to those uninvolved in the political process to realize that in a major contested election only a very small percentage of voters is actually undecided (Vavreck, 2016). Thus officials' membership in a party immediately provides them with a base of support that serves to protect them from the influence of the businesses. 
Given the uneven distribution of supporters of one political party or another among the various states and legislative districts, there are certain states or districts where one political party will have an advantage over the other (Hershey, 2007). On the other hand, there are states and districts where the electoral power of the two parties is more evenly matched. Based upon the above analysis, the more influence the political party has in a constituency, the less influence will the businesses engaged in CPA have, and vice versa. Thus in districts where one political party dominates, the elected official will feel free to act independently of the demands of the special interests. However, in districts where neither party dominates, the elected official will have to turn to the businesses engaged in CPA to impact the political landscape factors he or she needs to be re-elected.

\subsubsection{Transactional Versus Relational Approach to CPA}

Some scholars have raised the question as to whether corporations should take a proactive or reactive approach to CPA (Hillman et al., 2004). The proactive approach has been called "relational," since it involves the firm developing ongoing relationships with the politicians who impact its business. Examples of where such an approach makes sense would be in industries that are heavily regulated, such as utilities, or where the firm is such a large player in the market that political issues come up frequently, such as with General Motors or other very large companies. In contrast, the reactive approach has been called "transactional," since it treats government as something that is not a concern of the firm until government action might directly impact an interest of the company. At that time, the firm would have to take steps to address the specific political transaction that threatens its well-being (Holburn \& Vanden Bergh, 2008). Hillman et al. (2004) have argued that more research is needed on this question.

I argue, however, that a transactional approach is not an either/or alternative to a relational 
approach. Pursuant to the political landscape model, the two are actually entirely different constructs. On the one hand, a relational approach enables the firm to impact one of the three large factors that influence the politicians. Such relationships, however, can essentially be outsourced by hiring lobbyists as needed. As a result, the question of whether a firm should take a relational approach to politics or not is simply one of transaction costs (Kingsley et al., 2012). Essentially, if a firm finds itself in frequent engagement with government due to either its industry or its size, then it might be more cost effective to bring the relationship-building with public officials in-house rather than hiring lobbyists as needed. On the other hand, a transactional approach is what the firm needs to take every time it faces a public policy challenge. For every issue, the managers must consider who the politicians on that issue are. Then, the company must analyze the issue's relationship to the three factors of the political landscape. Finally, the firm will be able to determine whether it can influence the decision, and if so, how. Thus, the concepts of transactional and relational approaches to corporate political activity are not alternatives. Instead, they are entirely different dimensions.

Some might say that public policy is constantly evolving, and inserting oneself in the process of developing that policy is the essence of a relational approach. While this observation is accurate, the forward motion of policy is always achieved in significant moments, or critical events: an election, a committee vote, or the promulgation of a new rule, for example (Chandler, 2014; Choi, Jia, \& Lu, 2015). At each of these moments, businesses will need to determine which outcome they prefer and whether the outcome of that moment is sufficiently salient to motivate them to expend resources to influence it. The nature of political decision-making is much more dualistic than in the business world. Where several businesses can successfully operate in a single market, politics always results in at least one winner and one loser. While businesses may involve 
themselves in the policy-making process over time with the aim of establishing relationships with politicians that they can benefit from in the future, their ultimate goal must be achieving the desired outcome in their critical moment. Thus, successful practitioners of CPA will approach each moment as a new transaction, and they will deploy what resources they have available at that time to achieve their aim in that moment.

The fact that periodically groups with seemingly incompatible interests will cooperate in their efforts supports the argument that successful CPA is always transactional. For example, in the recent debate over approval of the Keystone XL pipeline, certain labor unions allied themselves with the energy industry (Yglesias, 2014). Overall, these groups appear to be unlikely collaborators (Aronoff, 2015), but on this one particular issue, their interests converge. For the union, it was the potential for high paying jobs (Yglesias, 2014). For the energy companies, it was access to cheaper oil (Transcanada Corporation, 2010). Thus, these two groups, historically at odds, and still opposing each other on a number of issues, found common ground on this one particular issue. Such unusual alliances are common in policymaking, leading Charles Dudley Warner to write that "politics makes strange bedfellows." Thus, successful practitioners of CPA will be able to set aside historic alliances and enmities in favor of a transactional analysis that determines what is the best position for the business on that issue at that time.

Taking such a calculated approach will generally not damage the business's long-term CPA efforts. There will be times when a firm has a policy position that conflicts with other factors influencing an elected official. Just because that politician might not be inclined to support the business's position as a result of the conflict with the other factors, does not mean that the politician will never support the business's position, just not on that particular issue. Thus the business cannot afford to damage the relationship over one issue, since it might need that politician's support in 
future issues. Successful businesses will thus be able to separate each issue from the other. By understanding the political landscape informing the decision of the politician, the corporate player will see why the politician cannot support it on that issue, and it will be able to move on to other politicians whose landscape might favor the business's position without jeopardizing the firm's relationship with any single official.

The above theoretical analysis leads us to a proposition that could form the subject of future research:

Proposition 1: Businesses engaged in CPA will approach each new issue as a separate transaction. In this way, they might be able to garner support from politicians who were unable to support the business's position on other policy issues due to (a) the politician's ideology, (b) political trends in the politician's constituency, or (c) the relationships of the politician.

\subsection{Hypotheses}

\subsubsection{Three institutional constraints impacting CPA}

In this way, it appears that the political market theory can be extended. Rather than characterizing as currency of exchange two of the three tools at the disposal of policy demanders - money and political support - I will characterize them as means of building relationships. Rather than ignoring the contextual factors within which these relationships take place, I consider the impact of the policy suppliers' ideology and the trends within their constituencies that might result in issues achieving saliency. The final element of the political market theory, information, might be of questionable value to the policy suppliers, however. Policy suppliers likely face information overload (Schuler et al., 2002), since demanders of every kind will be coming to them providing information to bolster their case, and since the suppliers separately will have sources of information such as their staffs or other governmental organizations (Schuler, 1996; Shaffer, 
1995). Policy suppliers will, by definition, have high social capital, since they were able to win the votes of sufficient constituents to be elected. High social capital has been linked to information overload (Oldroyd \& Morris, 2012). Similarly, political activity by suppliers has been found to be demanding of time and effort (Shaffer, 1995). Such demands are analogous to those placed upon entrepreneurs who have been shown to suffer from information overload (Baron, 1998). Indeed, firms tend to spend far more money on lobbying than they do on political contributions (Hillman et al., 2004; Johnson \& Kwak, 2013), and it appears that suppliers view lobbyists as sources of funding rather than sources of information (Admati \& Hellwig, 2013). This argument finds support in the political science literature which views lobbying not as persuasion, but as a "legislative subsidy" aimed at helping the politicians manage the flow of information (Hall \& Deardorff, 2006). Finally, within the realm of CPA, information is rarely unbiased and is frequently used as a weapon to bolster a policy demander's particular argument (Bonardi \& Keim, 2005), further increasing the policy suppliers' skepticism as to the value of any information policy demanders bring to them. Pursuant to cognitive dissonance theory, ideology tends to result in individuals discounting the information that disagrees with their beliefs (Harmon-Jones, 2002; Yeo, Xenos, Brossard, \& Scheufele, 2015). Thus, the value of information to policy suppliers is likely so low that it is a poor medium of exchange in the political market. As a result, I will limit its application in my model.

The model that emerges from this analysis of the current market theory of CPA is one that still views money and political support as valuable tools, but where these tools are in fact used by policy demanders to build relationships with the policy suppliers. The impact of such relationships will be negative as much as positive. Where the market theory notes the attraction such offerings might have to a policy supplier, it fails to consider the fact that the policy supplier might have ongoing relationships based upon these factors with other policy demanders who oppose the firm 
engaging in the CPA. Indeed, the lengths politicians go to in their effort to assist their long-time supporters is well documented, such as how the Clintons repeatedly risked their own political standing in their effort to assist the "friends of Bill" or "FOBs" (Mosk, Ross, Epstein, \& Park, 2016). Furthermore, I contextualize the interaction of CPA, noting two constraints that will limit the actions of the policy suppliers: the internal constraint of the policy suppliers' ideology, and the external one of the broader political trends in the policy suppliers' constituency that might result in an issue achieving salience and thus having the potential of impacting the reelection of the supplier. These three constraints, the relationships of the policy suppliers, their ideologies, and the larger political trends impacting their constituencies can be analogized as topographical barriers in a landscape around which the policy suppliers must negotiate.

Policy demanders engaging in CPA must be aware of how these three constraints will limit the options of the policy suppliers they approach for support. Based upon the above analysis, if a policy demander requests that the policy supplier take a position in opposition to one of these three factors - the suppliers' relationships, their ideology, or the political trends affecting their constituencies - the supplier will be less likely to respond favorably to the demander's entreaties. Even so, there remain options available to policy demanders. For example, it has long been known that firms, especially larger ones, are capable of impacting their environment (Child, 1972). If they can change their environment to be more favorable for their operations, so too can they impact the political trends in the constituency of a supplier whose support they seek, bringing attention to issues they wish to make salient and raising questions about issues that hurt their cause (Bonardi \& Keim, 2005). Indeed, a perfect illustration of how companies engage in such efforts is the dramatic recent growth of issue advertising, where policy demanders will purchase advertising to impact the opinions of voters in a certain policy supplier's district (Hall \& Reynolds, 2012). 
Similarly, policy demanders can work to establish relationships with policy suppliers over time with money and political support (Hillman \& Hitt, 1999), thus granting them access to the supplier and making it so that the supplier will be less likely to support the issue positions of the demander's opponents. In the alternative, firms can outsource that process to lobbyists whose business relies upon the establishment and maintenance of relationships with the policy suppliers. In effect, lobbyists can "rent" the relationships they have established over time to policy demanders. This approach seems to be favored by most businesses given the wide disparity between how much money firms spend on political contributions versus how much they spend on lobbying (Hillman et al., 2004; Johnson \& Kwak, 2013). Finally, although the supplier's ideology will be the most difficult factor for a policy demander to impact, this is one area where information might make a difference. It is possible that under certain circumstances policy demanders will be able to provide information to suppliers that changes their opinion about a specific issue. This is the one area where the final element of the political market theory might be useful, albeit in a very limited way. Generally speaking, it will be particularly difficult for policy suppliers to change their opinion where they have already publicly pronounced their view, given concerns over the public's dislike of politicians' inconsistent positions (Croco, 2016; Doherty, Dowling, \& Miller, 2016). Thus, not only must demanders engaging in CPA be aware of the three limiting factors in the political landscape, but they may actually be able to impact them in their effort to push the policy suppliers to support their position. 
Table 1 - Extending the Market Theory

\begin{tabular}{|l|l|}
\hline Market Theory & The Political Landscape \\
\hline "Exchange" & Institutional constraints \\
Policy demanders request consideration & Struggle per Resource Dependence Theory \\
3 currencies: & 3 factors: \\
1. Money & 1. Relationships \\
2. Political Support & 2. Political trends in supplier's constituency \\
3. Information & 3. Ideology \\
Environment not considered & Strength of political parties \\
No direction as to which suppliers to target & Target suppliers of moderate ideology \\
\hline
\end{tabular}

Table 1 clarifies how the Political Landscape theory extends the Market Theory of CPA. Where the market theory suggests that policy suppliers and demanders engage in an exchange within which demanders offer suppliers consideration, the Political Landscape envisions a relationship between the parties governed by three institutions that constrain the actions of the actors, but the actors can also modify with the application of sufficient effort. Where the market theory envisions a scenario in which the policy suppliers use their power over policy to extract currencies from policy demanders, the Political Landscape describes a struggle between the two parties in which, following resource dependence theory, each party seeks to reduce its dependence upon the other and thus reduce the other party's power over it (Hillman, Withers, \& Collins, 2009). Where the market theory suggests three currencies the policy demanders offer the suppliers, the Political Landscape points to three factors that will govern the relationship between the actors: the suppliers' relationships, the political trends in their constituencies, and their ideology. Where the market theory does not consider context in its analysis of CPA, the Political Landscape suggests that the strength of political parties in the suppliers' constituencies will moderate the influence of CPA upon that supplier. Similarly, since most policy suppliers have pre-existing ideological beliefs, policy demanders will have to determine what each policy supplier's beliefs are, and then 
target their CPA efforts at those suppliers whose ideology makes them most open to the policy demanders' entreaties, or at least not opposed to them. In this way, the Political Landscape approach adds nuance to CPA theory in extending the existing market theory.

The prior analysis leads to the following hypothesis:

Hypothesis 1: When CPA is successful, there will be a positive association between the position policy demanders support and the policy suppliers' (a) ideology (b) political trends in their constituency that might make an issue salient and (c) their personal relationships.

\subsubsection{The Impact of Political Parties on CPA}

Sitting opposed to the various interest groups attempting to achieve their governmental agenda are the political parties (Choi et al., 2015). Policy demanders are driven by certain specific policy goals which could be either ideologically-based such as those advocated by environmental groups or their pro-growth counterparts, or protection of self-interest such as those advocated by specific business organizations or labor unions. In contrast, the goal of the political party is the protection of its elected and appointed officials. The ideological make-up of the parties in the American system can be quite diverse (Thomsen, 2014; Williams-Wyche, 2014). Thus, the elected and appointed officials of each political party might range widely in their views, although that range has narrowed in recent years (Bafumi \& Shapiro, 2009). As a result, given their ideological diversity, the only factor unifying many of these officials might be their party affiliation. In contrast, what unifies members of organizations that are policy demanders is not their membership in the group, but the political goal that they share. Thus an environmental group may count Republicans, Democrats and Independents among its supporters, as would a pro-growth organization, a politically-active labor union or a firm engaging in CPA. Frequently, there may be

close connections between certain policy demanders and one political party or the other, such as 
the relationship environmental groups and labor unions have with the Democratic party. When issues arise that may put the group in conflict with the party, however, the group will leave the party, at least temporarily, to advocate for its policy position. For example, the Democratic party faced such a challenge when environmental groups and labor unions took opposing positions over allowing the construction of certain oil and gas pipelines (Yglesias, 2014). In each case, the policy demander would have supported or opposed policy suppliers based upon their policy position, while the political parties are unlikely to abandon their support of an official no matter what their policy view.

In this way, political parties can provide policy suppliers a countervailing force against the pressures policy demanders may apply to them. While the policy supplier may fear that the policy demander may withdraw its support or exert its strength to impact the supplier's political landscape, the suppliers can be confident in the fact that the institution of their political party will remain supportive. Certain states and legislative districts will lean heavily toward one party or another, while other constituencies will be more evenly divided. In those constituencies with a heavier partisan tilt, the political party will have the ability to essentially deliver the district's votes to its chosen candidate (Harbridge \& Malhotra, 2011), thus decreasing the potential impact policy demanders can have on the relevant political landscape. In more closely contested districts, however, the party will lack that ability, resulting in greater potential for the policy demanders to either help or hurt the suppliers' reelection effort.

This analysis brings me to my second hypothesis:

Hypothesis 2: The influence of business interests will be stronger in legislative districts where the two political parties are more evenly matched than in those where one party or the other dominates. 


\subsubsection{Effective CPA Targets Undecided Policy Suppliers}

Thus far, this paper has addressed what CPA is, what are its ground rules and its limitations.

The question remains how companies do CPA. The first step with any issue will be for policy demanders to analyze the political landscape of the policy suppliers who are decision-makers on the issue. In completing this analysis, policy demanders will determine that there are some suppliers who will be extremely unlikely, if not actively opposed, to the demanders' position. Similarly, there will be some suppliers who are likely to be immediately supportive, as determined by their political landscape. The supplier may have a strong relationship with the demander's leadership; or the demander may have a factory in the supplier's district, thus impacting the demander's overall political trends; or the demander may have a pro-business ideology, making him or her particularly supportive of the demander's position. With few exceptions, however, neither group will make up a majority at the beginning of the process, and so the policy demander will have to engage in further CPA to build support. The target of these CPA efforts, then, would be the policy suppliers who are neither supportive nor opposed to the demander's position, since that is where the policy demander will be able to turn undecided suppliers into supporters, hopefully resulting in a majority. For each of these undecided suppliers, the policy demander will have to engage the elements of the political landscape to encourage their support. For example, the demander might hire a lobbyist who has established relationships with the undecided suppliers, thus impacting the relationships element of the landscape. Similarly, the demander might employ issue advertising or grassroots organizing with the aim of making their issue salient with the constituency who elect the policy supplier, thus impacting the political trends of that supplier's district (Hall \& Reynolds, 2012; Hillman et al., 2004; Schuler et al., 2002). Finally, the demander may attempt to impact the supplier's ideology by providing information supportive of its position. 
Here, however, the policy demander may have the least success. Pursuant to cognitive dissonance theory, ideology tends to result in individuals discounting the information that disagrees with their beliefs (Harmon-Jones, 2002). As a result, the most difficult of the landscape's elements to affect is likely ideology, and as such, the most ineffective CPA efforts will be those that focus on policy suppliers who are either ideologically in favor or opposed to the policy demander's position.

The above analysis leads to my third hypothesis:

Hypothesis 3: There is an inverse U-shaped relationship between a politician's ideology and the CPA the firm engages in with that politician such that the firm will engage in comparatively less CPA with highly pro-business or highly anti-business politicians than with those whose attitude toward business issues is more moderate.

\subsection{Discussion}

I embarked upon this exploration of CPA primarily in response to two realizations. First, the market-based approach to explaining CPA seemed unable to explain certain realities of the political environment, such as the ability of businesses and other interests to pressure politicians to take a certain position, or the resistance of politicians in certain circumstances to offerings of money, information and constituent organizing, the purported currencies of the market theory. Second, the market theory in the management sciences, and the similarly influential interest group theories pioneered by Mancur Olson in political science, have received limited empirical support for their predictions (Hadani et al., 2015; Hadani \& Schuler, 2013; Hansen et al., 2005; Hillman et al., 2004; Shaffer, 1995; Zhang, Marquis, \& Qiao, 2016). These problems have led some to call for additional conceptual work in the field (Getz, 2001; Hart, 2004), a call I aim to answer.

By definition, CPA is a nonmarket strategy (Bonardi et al., 2006). It appears that the difference between market and nonmarket strategies are the stakeholders toward whom the actions 
are directed (Stevens et al., 2005). Market stakeholders are those with whom the firm has an economic relationship, such as shareholders, customers, suppliers, employees, and even competing firms (Stevens et al., 2005). Nonmarket stakeholders are those with whom the interaction takes place through other than economic means. Typically, the interactions involve relationships, and they are generally mediated by public institutions, such as regulators, elected bodies, and courts (Stevens et al., 2005).

Nonmarket strategies can play a critical role in the success of a firm. Some have found a relationship between nonmarket success and a variety of benefits to the firm, including the creation of first mover advantages (Frynas et al., 2006; Hillman et al., 1999). However there appears to be a hierarchy among these stakeholders, with some achieving greater saliency than others (Bundy, Shropshire, \& Buchholtz, 2013; Stevens et al., 2005). I would argue that managers rank the importance of stakeholders based upon the impact they can have on the firm's bottom line. Thus, even though the relationship with the nonmarket stakeholders is not explicitly an economic one, economics still drives the basis for the relationship (Baron, 1995). In some ways, then, certain nonmarket stakeholders might actually have a greater impact on the firm's performance than certain market stakeholders (Julian et al., 2008). For example, an environmental group the firm's managers ignore might be able to get a court order or a regulatory ruling that effectively shuts down the operation. In this way, such a nonmarket stakeholder would actually be more important to the firm's success than perhaps a supplier or group of employees who could be replaced. There might even be an interaction between market and nonmarket strategies. For example, unions might engage in both contractual and lobbying efforts to help their cause. Thus, a player that is clearly a market stakeholder would be engaging in nonmarket strategies.

The importance of this insight to scholars involves how to measure the impact of 
nonmarket strategies. In the past, studies have used measures other than performance to quantify the significance of these approaches (Stevens et al., 2005). These measures, however, are often more difficult to quantify than performance, and proxy variables to represent them can be approximations at best. For example, some studies have looked at corporate spending on social causes to determine the firm's social responsibility (Julian \& Ofori-dankwa, 2013; Marín, Rubio, \& de Maya, 2012). However, smaller firms, for example, might engage in CPA locally through activism in civic organizations. If such a firm receives some portion of its revenues from local government contracts or otherwise benefits from local government action, its activism would be extremely important to its success but would not be measured by this kind of proxy variable.

The political landscape model can provide scholars with some direction as to developing improved metrics. One study empirically assessed CPA by determining the success of utilities in gaining approval of their rate requests (Bonardi et al., 2006). This research, however, viewed relational and transactional approaches as alternatives. Pursuant to my argument, such a distinction is not valuable. Instead, there should be more studies such as that where a firm's success in achieving its transactional goals are a direct reflection of its political capabilities. Similarly, the political landscape model presents three factors businesses must address with the politicians. In some cases, those factors can be directly measured, such as by looking at the media coverage of an issue to determine if it rises to a political trend, or showing where certain legislators take positions that might not track what one would expect given their districts. Thus, a contribution of this article involves the development of methods to measure CPA activity.

Furthermore, applying institutional theory and agency theory to CPA has significant implications for their literature as well. For example, agency theory posited as a threat the misuse of corporate funds by managers contrary to the financial interests of the principals (Eisenhardt, 
1989; Matta \& McGuire, 2008; Shane, 2001). In my research, I suggest that opportunism may also result from non-financial motivations, such as where the managers might direct the firm to advocate a policy position that does not conform to the political views of the shareholders, or even worse, the firm's financial interests (see also Schulze, Lubatkin, Dino, \& Buchholtz, 2001). Where agency theory proposes taking steps to align the financial interests of the managers with those of the shareholders, one wonders how the shareholders could better align the political agendas of their managers with their own.

Similarly, institutional theory has been defined as a "generalized perception" that an entity is behaving in a way deemed desirable within a "socially-constructed system of norms" (Suchman, 1995: 574). Suchman (1995) did a remarkable job defining the different kinds of legitimacy and how firms can achieve them. Nevertheless, the target of efforts to achieve legitimacy remains a nebulous "socially-constructed system" (see also Gomez \& Jones, 2000). In this paper, I address the opposite side of Suchman's argument: the targets of efforts to achieve legitimacy. The system I identify is the political system, and I identify the players on either side of such efforts, as well as the specific mechanisms associated with each form of legitimacy. Thus, I have described the application of legitimacy in a particular system, how such application affects the views the publics have of the organization seeking legitimacy, and finally, how successful efforts at achieving legitimacy can inure advantageously to the organization's benefit. Such analysis could presumably be applied in other systems, such as the market that brings investors and firms together, for example. Thus, my research contributes to the literature on institutional theory by adding specificity to the application of legitimacy efforts.

Perhaps the most significant limitation to this research is its focus on politics of the United States. Granted, the United States remains the world's largest economy, and its political system is 
well-established, but it must be stated that this approach might not apply in other countries. As a result, scholars from other parts of the world might need to modify this theory to suit their own country's system, or they might need to develop a separate theory in and of itself. I make no claim that this theory applies anywhere except in the United States or other similar countries. Nevertheless, I hope it starts a process of exploring how the various political systems interact with their business communities.

\subsection{Conclusion}

In this chapter, I have proposed an extension of the prior political market theory that viewed CPA as a series of market interactions. The problem with that theory is that the political market tends to be rife with inefficiencies and opportunism. Any kind of actual contractual arrangement in this arena is completely unenforceable and might even be illegal. While it is true that the political market theory identified certain essential interactions in CPA, it needed an explanation as to how these contributions actually impact the process. Considering these elements as currency in a transaction is simply too limiting. In this way, my theory contributes to scholars' understanding of the CPA process. 


\section{CHAPTER 3: THEORETICAL EXTENSION -- WHY DO BUSINESSES ENGAGE IN CORPORATE POLITICAL ACTIVITY? AN AGENCY THEORY PERSPECTIVE}

\subsection{Introduction}

Corporate political activity (CPA) is a field that has garnered much attention among scholars over the past two decades. Despite the fact that CPA is a nonmarket activity, and as a result, outside the typical realm of strategy research (Bonardi et al., 2006; den Hond et al., 2014; Stevens et al., 2005), this attention is warranted. Since the regulatory era began in the 1960s, the impact of government on business has increased dramatically (Shaffer, 1995). At this point, regulation appears to impact just about every aspect of modern business activity (Lester et al., 2008). Businesses have responded to government's increasingly potent effect with activism aimed at either reducing regulations or turning government policy to their own benefit (Hillman et al., 2004; Shaffer, 1995). While many American executives dislike government and politics and find CPA distasteful, they also believe that it can lead to competitive advantage (den Hond et al., 2014; Frynas et al., 2006; Pearce et al., 2008; Schuler et al., 2002; Shaffer, 1995; Shaffer \& Hillman, 2000). Frynas et al. (2006) specifically found that government relations activities can lead to first mover advantage in developing countries (see also Kingsley et al., 2012). In the United States, Schuler (1996) showed that CPA can impact trade policy (see also Lindeque \& McGuire, 2010); Yackee and Yackee (2006) found that businesses engaging in CPA have a greater impact on regulators than other non-business interests; Hansen et al. (2005) found that CPA is related to successful government contracting; and Hadani and Schuler (2013) did find a link between CPA investments and firm performance in highly regulated industries. As a result, it appears that the attention shown CPA by scholars is justified. 
Notwithstanding such focused treatment, there is lack of clear explanation in the literature as to why businesses engage in CPA. For example, Hadani and Schuler (2013) could not find a link between firm performance and CPA in most industries, while Hillman (2005) did find a connection between firm performance and having politicians on the board. Similarly, Schuler et al. (2002) could not establish a relationship between firm slack and CPA, although that finding has also been disputed (Hillman et al., 2004). Furthermore, Hansen et al. (2015) did not find that corporate spending on politics increased in the wake of the Supreme Court's decision in Citizens United v. Federal Election Commission, despite expectations that the Supreme Court's making it easier for firms to spend treasury funds on political activity would result in a higher level of CPA (see also Bebchuk \& Jackson, 2010). Even in the political science literature, efforts to find empirical support for Olson's theory of firms (1965), which argues that firms engage in CPA to gain access to public goods, have been stymied (Hansen et al., 2005). As a result, an unresolved question exists that scholars in both management and political science have called to be researched (Hojnacki et al., 2012; Holburn \& Bergh, 2008; Néron, 2009; Pearce et al., 2008).

In this paper, I use agency theory and stewardship theory to create a more nuanced model to explain why businesses invest in CPA. I argue that decisions to invest in CPA could be driven by one of two motivations on the part of the firm's top managers. On the one hand, managers engage in CPA to influence policy that could benefit the firm. This stewardship-based approach to understanding CPA has been the dominant view of management scholars thus far (Hadani et al., 2015). Less researched has been another possible motivation of managers to engage in CPA: the use of the firm's resources at their disposal to pursue a personal political agenda that may or may not benefit the firm. In effect, this view represents an agency approach to understanding CPA, where the managers are engaging in opportunism, defined as "self-interest seeking with guile" 
(Williamson, 1985: 30, 47). My expectation is that the more discretion managers have over resources, the more likely the managers are to behave opportunistically and to engage in a selfserving political program. However, where those factors are limited, the managers would instead behave more like stewards. I also predict that the best-performing firms will be those where the managers behave as stewards instead of behaving opportunistically. I test this theory empirically using a unique database and find support for my predictions.

This paper contributes to the literature in at least two ways. First, I address an issue that has puzzled scholars regarding the motivation of managers to engage in CPA. Second, I clarify the role of slack in promoting CPA, and demonstrate the relative importance of absorbed slack in this activity.

\subsection{Theory and Hypotheses}

\subsubsection{Agency Theory and Stewardship Theory}

Agency theory has been described as the "metaphor" of a contract (Eisenhardt, 1989: 59). By definition, however, agency theory is not a metaphor of a contract; it is in fact a legal contract (Lan \& Heracleous, 2010). The management theory is based on the legal concept that principals can delegate authority to agents to act on their behalf(Dalley, 2011). From the beginning, lawyers have been aware of the problems that can arise in such an arrangement. To attorneys, the answer seems simple: build a stronger contract. By drafting a contract that eliminates discretion on the part of the agents, lawyers argue that the agents will have no choice but to follow the rules (Dalley, 2011; Lan \& Heracleous, 2010).

Economists recognized a problem with this purely legalistic approach. The basis for this insight was Coase's conception of the boundaries of the firm as based on whether contracts can be most efficiently managed internally or externally (Scott, 2004; Williamson, 1981). Agency theory, 
like Transaction Cost Economics, suggested that managing these contracts has associated costs, and the goal of economic entities should be to minimize those costs (Dalton, Daily, Certo, \& Roengpitya, 2003; Hoskisson et al., 1999; Williamson, 1981). Thus, to avoid the risks of opportunism, principals would incur costs (Eisenhardt, 1989; Gomez-Mejia \& Balkin, 1992; Hagen \& Choe, 1998; Lado, Boyd, \& Hanlon, 1997). Above and beyond the obvious legal costs involved with drafting extensive contracts, economists pointed out that other problems arising from this relationship would have their own costs (Rumelt, Schendel, \& Teece, 1991). In particular, moral hazard arises from the fact that agents' own resources are not at risk. The losses resulting from this incongruity is one cost the economists pointed to (Foss \& Lindenberg, 2013). Similarly, adverse selection is the problem that results from the fact that the principals typically have less information than the agents. The gap between what the principals find out from the agents themselves or from other sources and the true nature and intentions of the agents leads to inefficiency (Eisenhardt, 1989; Ofori-Dankwa \& Julian, 2013). Thus, the economists took agency theory another step from its legal origins, adding nuance to its understanding of the costs and risks that arise from such a relationship.

In response to the problems pointed to by economists, management scholars looked for possible solutions (Rumelt et al., 1991). To address the potential for shirking, scholars proposed increased oversight; to address moral hazard, better alignment of the interests of the two parties (Sieger, Zellweger, \& Aquino, 2013). Each of these approaches, however, had its own associated costs and disadvantages. For example, in addition to the actual costs of overseeing the behaviors of agents, principals may experience lesser performance by the agents. Empirical studies have validated that such shrinkage can result (Eisenhardt, 1989). Similarly, efforts to more closely align the interests of top managers with those of shareholders have led to the granting of stock options. 
Yet, the granting of stock options has become the basis for the extreme increases in CEO pay relative to the pay of other employees. This result might not bother the shareholders if this high pay for top managers results in superior returns on the shareholders' investment, but a metaanalysis conducted by Dalton et al. (2003) did not support that proposition. Thus, as a number of scholars have already pointed out, the standard solutions proposed in response to the agency problem are unsatisfying at best (Davis et al., 1997; Ghoshal, 2005).

To address this problem, some scholars have proposed stewardship theory as an alternative to agency theory (Aguilera, Filatotchev, Gospel, \& Jackson, 2008; Hoskisson et al., 1999). As recently as 2012, Hernandez (2012) pointed out that stewardship theory is still ill-defined, and that scholars have mostly addressed it in contrast to agency theory. In general, the difference between the two has to do with the motivation of the managers. Where agency theory argued managers are motivated by extrinsic incentives, such as financial rewards or more intense supervision, stewardship theory suggested that intrinsic rewards, such as the appreciation of various stakeholder groups, could also be a motivator (Chrisman, Chua, Kellermanns, \& Chang, 2007; Davis et al., 1997). However, this theory has been criticized for advancing a selfless view of managers' motivation that discounted opportunism (Sieger et al., 2013).

\subsubsection{An agency inquiry into $\mathrm{CPA}$}

Hadani and Schuler (2013) found that CPA was not related to firm performance except in industries that are highly regulated. This conclusion raises the question that if CPA is not related to performance, why do firms engage in it? Apparently, despite CPA appearing to be a poor use of firm resources, firms continue to spend on it (Hadani et al., 2015; McDonnell \& Werner, 2016).

The traditional way management scholars have understood CPA has been through the lens of stewardship theory, which essentially assumes that the managers engage in CPA to advance 
policies that will benefit the firm (Hadani et al., 2015). Research has shown that government policy can directly impact the competitiveness of businesses, and as such, businesses should push for policies that will assist them in achieving competitive advantage (den Hond et al., 2014; Frynas et al., 2006; Pearce et al., 2008; Schuler et al., 2002; Shaffer, 1995; Shaffer \& Hillman, 2000). Indeed, it appears that stewardship theory has been the primary basis for scholars' investigations into nonmarket strategies (Mellahi, Frynas, Sun, \& Siegel, 2016). Scholars have also endeavored to develop alternate explanations for CPA. Hadani et al. (2015) argue that CPA represents opportunism on the part of top managers seeking to advance their own personal ideological agenda. Managers empowered to use the resources available within the firm could fund CPA that satisfies their personal political goals, rather than building support for policy that will assist the firm's competitiveness. In support of this idea, Hadani (2012) found that firms with higher levels of institutional ownership - in effect, firms where the owners have the ability to provide stricter supervision of managers-have lower levels of CPA.

\subsubsection{The role of managerial discretion}

Hadani et al. (2015) found some support for the proposition that managerial discretion would be positively related to CPA. In other words, where the firm's managers have more ability to impact the activities of their firms, those firms tend to undertake more CPA. Managerial discretion refers to the latitude of options top managers have in making strategic choices (Boyd \& Salamin, 2001; Rajagopalan, 1997). If we accept agency theory's premise, we can assume that the greater decision-making managerial discretion would result in a certain amount of opportunism. If, as I theorize above, one form of opportunism might be CPA aimed at advancing the top managers' own personal ideological agenda, then one would expect to see more of that kind of opportunistic CPA where the managers' hands are freed by greater discretion (Clayton \& Bower, 
1996; Finkelstein \& Hambrick, 1990; Hadani et al., 2015; Hambrick \& Finkelstein, 1987; Wangrow, Schepker, \& Barker, 2015). On the other hand, where there is less managerial discretion, top managers will be limited in the tactics and strategies they can engage in (Boyd \& Salamin, 2001). In essence, the managers will be required to act on behalf of the shareholders' interests, rather than their own. If we expect that one kind of opportunism might involve CPA aimed at benefiting the managers' personal political priorities rather than the practical needs of the firm, this lack of discretion will force managers away from such opportunism and instead toward CPA that will ultimately benefit the shareholders.

Based on the above arguments, I can predict the following hypothesis:

Hypothesis 4: Managerial discretion will have a negative effect on CPA focused on the interests of the shareholders.

\subsubsection{The role of slack}

To engage in opportunistic CPA, managers must have access to resources for those CPA efforts. CPA can be a relatively expensive undertaking (Apollonio \& La Raja, 2004; Shaffer, 1995). Although the potential financial returns from successful CPA efforts can be enormous (Shaffer, 1995), and although many firms view CPA as a cost of doing business (Kingsley et al., 2012), it is hard to imagine that most firms, particularly those firms in industries facing less government regulation, would view CPA as a critical expense. Thus, in firms where managers have less access to resources, even if those managers have the inclination to engage in self-serving CPA, they will not have the ability to do so. On the other hand, in cases where CPA is critical to the firm's success, such as in more-regulated industries or where the firm sells to the government, firms will continue to expend funds on CPA even as other discretionary expenses are cut (Schuler et al., 2002). 
Slack has been defined as "resources in excess of the requirements necessary for the efficient operation of a firm" (Huang \& Li, 2012: 382). Overall, slack can be divided into at least two elements: financial slack, sometimes called available slack, and absorbed slack (Love \& Nohria, 2005). Financial slack is "typically used to refer to the amount of liquid resources a company has for the discretionary uses of management" (Natividad, 2013: 847). This kind of slack, however, would be readily visible to shareholders on the company's financial statements, and as liquid resources, they would be available for distribution to shareholders through dividends or for investment in projects aimed at increasing the company's stock value (Kim, Kim, \& Lee, 2008). On the other hand, absorbed slack would be harder for shareholders to see, although the managers themselves would be well aware of it (Love \& Nohria, 2005). Absorbed slack is said to exist in the firm as "excess costs, such as unused capacity and skilled employees" (Huang \& Li, 2012: 382). Absorbed slack has been shown to be accessed when firms restructure to address financial difficulties (Love \& Nohria, 2005). Thus, if managers wish to engage in a self-serving behavior, such as pursuing personal political agendas, they could do so without raising shareholder concerns by accessing resources buried as absorbed slack. Furthermore, given the finding that firms use absorbed slack to reorganize during financial crises (Love \& Nohria, 2005), availability of absorbed slack indicates that a firm is not facing financial constraints that would curtail managers' discretionary expenses. As a result, if managers wish to engage in self-serving CPA, they would likely have to be in firms with higher absorbed slack.

The relationship between managerial discretion and absorbed slack can be characterized as a mediation relationship. On the one hand, where managers have discretion and wish to engage in opportunism, they can do so without alerting shareholders to the availability of these resources by building them into the firm's absorbed slack. This could be done by managers creating budget line 
items that they do not intend to actually fund, making it appear as if the funds are unavailable for discretionary spending when in fact they are (Moulick \& Taylor, 2017). Indeed, some have distinguished the two forms of slack as based on whether the assets are committed to a specific purpose or not (Moulick \& Taylor, 2017; Tan \& Peng, 2003; Wefald, Katz, Downey, \& Rust, 2010). However, just because funds are committed to a purpose does not mean that they eventually are spent as was supposedly intended (Anderson, Asdemir, \& Tripathy, 2013). This fact helps explain the finding in prior research that agency theory better explains absorbed slack than financial slack (Tan \& Peng, 2003). Thus, where there is greater managerial discretion, one can expect greater absorbed slack. At firms where managers behave opportunistically by taking advantage of their discretion and concealing assets in absorbed slack, I expect those managers to behave similarly opportunistically with regard to their CPA. On the other hand, where managers choose to focus their efforts on the interests of the shareholders despite their ability to behave opportunistically due to higher levels of managerial discretion, in effect not storing resources as absorbed slack despite their ability to do so, I expect those managers to also behave in the shareholders' interests when it comes to CPA. As a result, one can imagine a partial mediation relationship as shown in figure 3 . 
Figure 3 - Conceptual Model

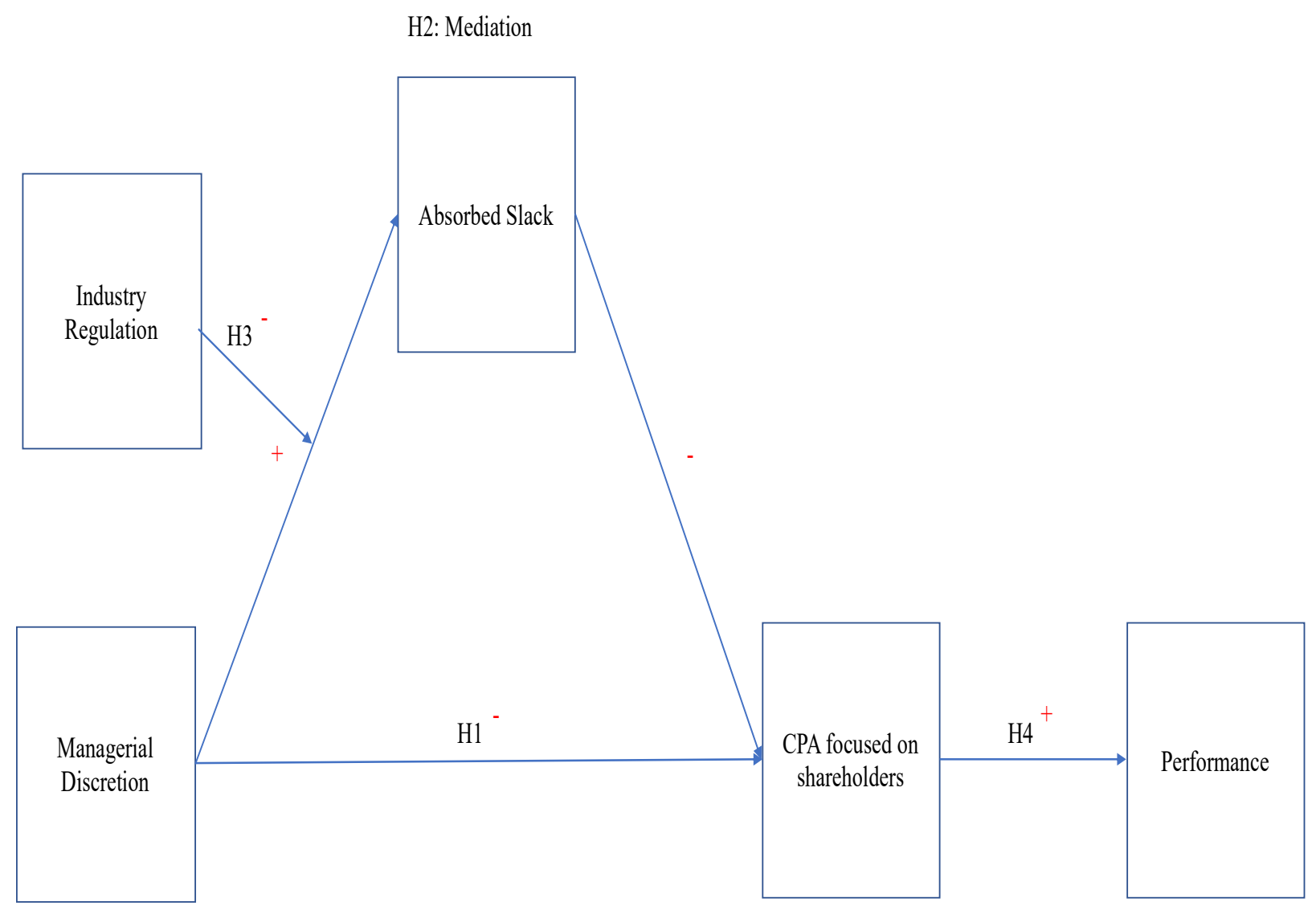

The above analysis leads to the following hypothesis:

Hypothesis 5: Managerial discretion will have a negative and indirect effect via absorbed slack on CPA focused on the interest of the shareholders such that managerial discretion will be positively associated with absorbed slack and absorbed slack will be negatively related to CPA focused on the interests of the shareholders.

\subsubsection{Regulation}

Hadani and Schuler (2013) showed that there is a positive relationship between the level of regulation a firm faces, its level of CPA, and firm performance. This finding is logical in that 
regulated firms would be those most impacted by governmental decisions, and as a result, effective CPA would be essential to those firms to ensure they operate within a favorable environment. Indeed, to a much higher degree than firms in other kinds of industries, regulated firms can directly impact their environment through the effective use of CPA (Bonardi et al., 2006). The key point here, however, is that these firms need to successfully mold policy to achieve that goal. Changing policy will require firms to build coalitions of politicians until they gain majority support. Majorities are achieved by wooing undecided politicians to their point of view, not by attacking or rewarding politicians who already have hardened positions. ${ }^{1}$ As a result, given the critical nature of successful CPA to regulated firms, one can expect that more-regulated firms will be conscious of the need to build majority coalitions of politicians, and thus will focus their efforts on the undecided moderates. As a result, industry regulation will in effect reduce the ability of top managers to behave opportunistically in their CPA.

As discussed earlier, managerial discretion allows top managers to divert resources into absorbed slack, and thus it enables top managers to behave opportunistically. Since managerial discretion refers to the latitude of options top managers have in making strategic choices (Boyd \&

${ }^{1}$ Political scientists generally argue that interest groups, including businesses, tend to advocate their positions to politicians who were neither supportive of nor opposed to the interest group's goal and focus their lobbying essentially toward the uncommitted ideological moderates who enter the debate at issue without predispositions; see Hall, R. L., \& Deardorff, A. V. 2006. Lobbying as Legislative Subsidy. The American Political Science Review, 100(1): 69-84. This idea makes intuitive sense. Consider a piece of legislation moving through the U.S. Senate. With one hundred senators, if forty-five senators favor the business's position, and forty-five are opposed even before the issue comes up for consideration, a not uncommon situation due to the profound ideological commitments held by most politicians - see Iyengar, S., \& Hahn, K. S. 2009. Red Media, Blue Media: Evidence of Ideological Selectivity in Media Use.

Journal of Communication, 59(1): 19-U16, Thomsen, D. M. 2014. Ideological Moderates Won't Run: How Party Fit Matters for Partisan Polarization in Congress. Journal of Politics, 76(3): 786-797. - the firm should spend its limited resources convincing the ten who have not yet decided which way to vote. If from those ten uncommitted legislators the business can convince six to support its position, the business will gain majority support and achieve its legislative end. Thus, rather than expending limited resources to talk to all one hundred senators, the business can target the ten undecided ones with fewer resources to achieve the same goal. 
Salamin, 2001; Rajagopalan, 1997), and government regulation "restricts some of the strategic options available and most of the decision-making and planning functions are shifted away from a firm's managers and boards to public officials" (Pugliese, Minichilli, \& Zattoni, 2014: 1191), it stands to reason that more regulation will result in less managerial discretion (see also Finkelstein \& Hambrick, 1990). As a result, the exogenous force of industry regulation (Luo, 2003) will reduce the discretion of managers to build resources as absorbed slack; thus it in effect moderates the impact of managerial discretion on absorbed slack. This argument leads to the third hypothesis:

Hypothesis 6: Industry regulation will negatively moderate the relationship between managerial discretion and absorbed slack.

\subsubsection{CPA and performance}

Finally, political positions can result in extreme emotions (Marcus \& Mackuen, 1993; Valentino, Brader, Groenendyk, Gregorowicz, \& Hutchings, 2011). Research has shown, however, that executives may harbor certain personal political views that are different from the political views they publicly espouse on behalf of their company (Adams \& Hardwick, 1998). Agency theory, then, points to a potential issue. The interests of the shareholders likely correlate to doing effective CPA, since CPA can affect the firm's success (Shaffer, 1995), and effective CPA, pursuant to the analysis above, requires that the firm's top managers engage with more moderate politicians. Top executives, however, have their own views, which tend to be more conservative than moderate (Adams \& Hardwick, 1998). If the managers consider themselves as trustees for the shareholders, as stakeholder theory suggests, they will likely work with the moderate politicians to maximize firm performance (Adams \& Hardwick, 1998; Aguilera et al., 2008). On the other hand, if they act more as agents, as agency theory predicts, there is the possibility that they will use company resources to benefit the political causes they support rather than the ones that will 
necessarily lead to higher performance (Davis et al., 1997). Thus, there could develop a divergence of interests between the shareholders and the managers, creating the typical agency problem (Eisenhardt, 1989). Interestingly, agency theory generally predicts that such differences will occur over financial issues, such as pay and equity; in this case, the force driving the rift would be the political preferences of the executives against the financial interests of the shareholders (Nyberg, Fulmer, Gerhart, \& Carpenter, 2010). Given that the American public tends to take a negative view of CPA (den Hond et al., 2014), the potential damage such rogue actions could have on a company's value are real. Consider the outrage sparked when retailers Best Buy and Target made large political contributions to a political group opposed to gay marriage in 2010 (Mullins \& Zimmerman, 2010). Furthermore, American law makes it very hard for shareholders to monitor and control the political activities of managers (Bebchuk \& Jackson, 2010), opening the door for agency problems (Eisenhardt, 1989). Thus, if one assumes that opportunism on the part of top managers ultimately hurts firm performance, as agency theory seems to imply, then it follows that firms where top managers engage in CPA opportunistically will not perform as well as firms where top managers focus their efforts on improving performance for shareholders.

The above analysis leads to my final hypothesis:

Hypothesis 7: CPA focused on the interests of the shareholders will have a positive effect on firm performance. 


\section{CHAPTER 4: METHODS}

\subsection{The Sample}

To test the hypotheses 1-3, I constructed a unique database from a number of sources. Such an approach is accepted in CPA research (see e.g. McDonnell \& Werner, 2016). First, I sourced financial contribution data from OpenSecrets.org (Apollonio \& La Raja, 2004), selected out contributions from the 2014 electoral cycle that were identified as being donated by firms in the sector "Misc Business," and sorted that data by member of Congress. I selected contributions from this sector since it is a sector that is both a significant contributor to the campaign finance system as well as one that represents a general pro-business approach. From their websites, I downloaded the Congressional scorecards from the Club for Growth, the U.S. Chamber of Commerce and matched the aggregate scores from these organizations as well as specific targeted votes with the members of Congress (Groseclose, Levitt, \& Snyder, 1999). Next, I identified each member of Congress with dummy variables representing whether they were incumbents in the 2014 election. Then, I combined this data with the general election results from the last election each member of Congress participated in, urban population data from the U.S. Census Bureau, and the state's probusiness rating according to the U.S. Chamber of Commerce foundation (2013). Lastly, following McKee and Teigen (2009), for each member of Congress, I added a dummy variable for the region of the country that member represented. From this combined database, I selected my variables. All variables were standardized except for dummy variables and the pro-business rating, since that data is uniformly distributed. Finally, I organized this data by member of Congress, resulting in a sample size of 525 including 98 Senators and 427 Representatives.

For hypotheses 4-7, I used the same data with some modifications. For example, I added data on firm performance, slack, industry and size from Compustat. I then combined the data from 
the above databases, resulting in matched data of 26,205 contributions by 436 companies made to 287 congressional candidates. After I combined multiple contributions by a firm to an individual candidate, I ended up with a database of 11,054 firm-candidate contribution combinations. Next, I attached data regarding the level of federal government regulation experienced by each contributing firm based on their industry from regdata.org (Al-Ubaydli \& McLaughlin, 2014). Next, to determine the partisan performance of the recipient's district, I added to each record the most recent version of the partisan voter index, which has been produced by the Cook Political Report and Polidata since 1997 (Wasserman \& Finn, 2017). Finally, I combined these data with demographic data for the recipients' districts from the U.S. Census Bureau, such as percentage of urban and rural populations. From this combined database, I selected my variables. Since the dependent variable for these hypotheses did not appear to display a normal distribution, I corrected for skewness by calculating the natural log of that variable (Dushnitsky \& Lenox, 2005; Julian \& Ofori-dankwa, 2013).

\subsection{Variables}

\subsubsection{Dependent Variables}

There are three dependent variables, one for each of the three hypotheses. For hypothesis 1, the dependent variable is how each member of Congress voted on the so-called "CROmnibus" bill, the budget deal that passed late 2014 that allowed the U.S. Federal government to remain in operation, and a vote that was targeted as important to business by the U.S. Chamber of Commerce. This legislation passed just hours before a deadline that would have resulted in a shutdown of the federal government - the result of a high-stakes dispute between Republicans and Democrats over what government spending should be increased and which should be decreased, defense or domestic discretionary, and whether such spending should be funded with tax increases or 
spending cuts (Chappell, 2014). From business's perspective, shutting down the government would have been disastrous since it would put a stop to many programs businesses rely upon, and it could hurt the overall economy (Zetlin, 2018). This vote was a good choice for my test because it was controversial, passing the House with a narrow margin of 219-206, both parties were split, it occurred after the election, and it was targeted by the U.S. Chamber in both the Senate and the House of Representatives. In essence, my test would look at whether the three elements of the political landscape would make a member of Congress more or less likely to vote for this bill. This variable is dichotomous, with 1 indicating a vote in favor of the bill, which is the Chamber's favored position.

For hypothesis 2, the dependent variable is the amount of money contributed to the member of Congress by donors identified as being part of the sector "misc business." Amount of political contributions is reflective of level of CPA (Hansen \& Mitchell, 2000). This sector accounted for 140,140 individual contributions and 23,996 from registered political action committees (PACs). This sector includes industries as diverse as manufacturing, retail sales, and lodging/tourism, to name a few - essentially all industries that do not fit into another of the larger categories. For comparison, this sector represents the fifth largest number of PAC contributions during this cycle, after only the ideological/single issue sector, the labor union sector, the finance/insurance/real estate sector, and the health sector, and it ranks just above the energy sector and the communications sector. Overall, this sector represents $14.5 \%$ of the total PAC contributions made during the 2014 election cycle.

For hypothesis 3, I used the Club for Growth aggregate score for each member of Congress based upon their Congressional report card (see Groseclose et al., 1999). Advocacy organizations will frequently produce a document in which they list the various votes they consider 
important, and list how each politician voted on that issue. Each year, the Club for Growth will publicize this list, showing how each member of Congress voted on its prioritized issues. Over time, the Club for Growth will combine these scores into a cumulative score for the member of Congress on how each voted on its key issues. Thus, the higher the cumulative score, the more ideologically aligned the member of Congress is to the Club for Growth, while those with the lowest scores will be those most opposed to the organization. In this way, advocacy organizations can specify which politicians voted most in favor of their agenda, earning a score of 100, signifying that the member of Congress voted in favor of the Club for Growth's position $100 \%$ of the time, and which did not, thus earning a score of 0 . These are absolute scores, not calculated relative to how other members of Congress voted. The use of organization scorecards in CPA research is a common approach (Groseclose et al., 1999). This organization is pro-business and pro economic development. The group is more polarizing than the U.S. Chamber of Commerce, and is viewed as a key opponent by many environmental advocates. As a result, the legislative strategy for this group is more focused than that of the more moderate and inclusive Chamber.

For hypotheses 4-6, to operationalize CPA, I matched each contribution in my database to the U.S. Chamber of Commerce cumulative score for the member of Congress ${ }^{2}$ who received it. Then, I transposed that score such that a $50 \%$ Chamber rating would equate to 100 , and the farther away the score was from 50, the lower the index number. Next, I multiplied the resulting

${ }^{2}$ The U.S. Chamber of Commerce publishes a list of votes that its legislative unit prioritizes and which way the Chamber wants members of Congress to vote. Each year, the Chamber will publicize this list, showing how each member of Congress voted on its prioritized issues. Over time, the Chamber will combine these scores into a cumulative score for the member of Congress on how each voted on its key issues. Thus, the higher the cumulative score, the more ideologically aligned the member of Congress is to the Chamber, while those with the lowest scores will be those most opposed to the Chamber. However, members of Congress with scores closer to $50 \%$ will sometimes vote with the Chamber, sometimes against it, suggesting a more moderate position on these issues, being neither fully pro-business nor pro-regulation. As a result, the most moderate members of Congress will be those with a cumulative Chamber of Commerce voting record closer to $50 \%$, while those with scores closer to either $100 \%$ or zero will hold more extreme views. 
number for each recipient of the contributions by the amount received from each firm. In this way, I account for circumstances where a firm might make very large contributions to more moderate candidates and smaller contributions to more extreme ones, and vice versa. Finally, I divided my dataset into two parts: one where the variable described above is above the median value, one where it is below. The records where the CPA focus is above the median therefore constitute the firm-candidate contribution combinations where the firms are engaging in CPA focused on the interests of shareholders, based on my argument above that the most cost-effective CPA will be aimed at the politicians who are undecided, located in the uncommitted, moderate middle. I log transformed this variable to minimize potential skewness in the data (Lee, 2010; Oh, Chang, \& Kim, 2016).

Finally, for hypothesis 7, Return on Assets (ROA) is a variable commonly used in strategy research to measure performance (Houthoofd \& Heene, 1997; McNamara, Deephouse, \& Luce, 2003). I calculated this variable as the ratio of net income to total assets (Jayachandran, Kalaignanam, \& Eilert, 2013).

\subsubsection{Hypotheses 1-3 Independent Variables}

Hypothesis 1. Due to the fact that this hypothesis sought to test the importance of all three elements of the political landscape to a policy supplier's position on an issue, I included three independent variables here. First, to represent relationships, I used the amount contributed by the sector misc business to the member of Congress. Financial contributions are considered reflective of the relationship between the donor and the recipient politician (Brown, Drake, \& Wellman, 2015; McKay, 2012). Second, to represent ideology, I included the U.S. Chamber of Commerce's cumulative rating from its 2014 Congressional scorecard (Groseclose et al., 1999). Finally, to represent the political trends in the supplier's constituency, I included the pro-business rating by 
the U.S. Chamber of Commerce Foundation for the state the member of Congress represents (Poe, 2013). Other research in this field has also used pro-business ratings by policy advocacy groups as indicative of the pro-business orientation of a body politic (Peksen, Blanton, \& Blanton, 2017). The pro-business rating is based upon policies passed by state legislatures and implemented by governors (Poe, 2013). In states where there is strong support for pro-business policy among the voters, these elected officials would tend to implement a more pro-business agenda, resulting in a higher rating. Similarly, in states with more pro-regulation electorates, the elected officials will tend to be less business-friendly. Thus, the level of pro-business orientation the state follows is likely a good indicator of the level of pro-business orientation of the state's voters overall.

Hypothesis 2. The independent variable for this regression is the level of partisan influence in the district of the member of Congress. For this variable, I relied upon the most recent version of the partisan voter index, which has been produced by the Cook Political Report and Polidata since 1997 (Wasserman \& Finn, 2017). Using results averaged from the last two presidential elections, this index indicates the level of partisanship a district displays in its voting patterns relative to the nation as a whole. This data has been used in political science research as a measure of partisanship in a congressional district (Jacobson, 2013). In a district or a state displaying highly partisan behavior in its voting patterns, the primary election will have more of an impact than the general election on the ultimate selection of the elected official (Ansolabehere, Hansen, Hirano, \& Snyder, 2007). In those districts that tend to have competitive primaries but relatively noncompetitive general elections, the institutional party will have more influence (Hassell, 2016). Thus, districts with a higher partisan performance, and thus a higher partisan voter index, will tend to have more powerful political parties than those with more competition in the general elections.

To test Hypothesis 3, I measure the level of effort policy demanders make to influence the 
position of specific members of Congress. Specifically, I used OpenSerets.org to obtain amount of money spent on issue advertising in each state by the American Petroleum Institute (API) in the period before the vote on the Keystone XL pipeline, an issue strongly supported by both the energy industry and the Club for Growth. The API is an industry trade organization with over 625 member companies working in the oil and gas industries (American Petroleum Institute, 2018). The API claims to speak for the oil and gas industry, and engages in advocacy on its behalf. Since the oil and gas industry was strongly supportive of the Keystone XL pipeline development, the API aggressively advocated for the legislation's passage, including purchasing independent television advertising in the media markets affecting the states of targeted Senators (Tumbull, 2016). As a result, this single vote provides me with a specific case in which a policy demander will target its CPA toward specific policy suppliers, allowing me to determine which policy suppliers it targeted. I used the issue advertising aimed at 98 Senators as representative sample for this research. Since I hypothesized a quadratic relationship here, I included both the variable and its square in the regression.

\subsubsection{Hypotheses 4-7 Independent Variables}

Managerial discretion. To measure this variable, I followed Finkelstein and Boyd (1998) as follows: Munificence (market growth) + R\&D intensity (R\&D expense/sales) + Advertising intensity (Advertising expense/sales) - Capital intensity (Property, Plant and Equipment Total

$($ Net)/Employees) + Herfindahl index for the industry. All elements were standardized before performing the calculation.

Absorbed slack. I followed Love and Nohria (2005) and operationalized absorbed slack as the ratio of sales, general and administrative (SG\&A) costs to sales. 
Regulation. To operationalize the level of industry regulation, I added the number of industry-relevant restrictions for each 4-digit NAICS code for the period of 2010 to 2014 from the regdata.org database (Al-Ubaydli \& McLaughlin, 2014). I then converted these 4-digit NAICS industries into 4-digit SIC industries to match them to my data.

\subsubsection{Hypotheses 1-3 Control Variables}

Note that not all controls were included in the regressions testing all the hypotheses.

General election result. This is the percentage of the vote the member of Congress received in the prior election. It is often argued that political demanders are more likely to support entrenched incumbents since they are more likely to be reelected, and thus more likely to be present when the demanders' issues come before Congress (Perry \& McWhirter, 2010). As a result, I expect that the safer an incumbent's position, based upon his or her margin in the last election, the more that official will be able to raise from all groups irrespective of ideology.

Incumbent dummy variable. Political science research has established that there is value to incumbency for elected officials (Schaffner, 2006). This advantage can take many forms, including access to resources and the fact that incumbents face less competitive campaigns (Benoit \& Marsh, 2008; Cox \& Katz, 1996). As a result, I controlled for incumbency with a dummy variable that was 1 when the politicians were incumbents in the 2014 election, a zero when they were not. I did not include this variable in my tests of hypothesis 3 since, by definition, the American Petroleum Institute would have been only targeting incumbent members of the Senate with their CPA efforts, thus meaning that this sample only included incumbents.

Urban population percentage. It has been shown that the political environment of urban areas is quite different from that of more rural areas (DelReal \& Clement, 2017; McKee \& Teigen, 2009). As a result, I controlled for this factor. Calculated from census data, this variable was 
included due to the different voting patterns displayed by urban versus rural communities.

Region. Since political dynamics vary based upon geography, I included dummy variables for four of the five regions identified by McKee and Teigen (2009). For each of the regions, Midwest, Pacific, South and West, there is a 1 in the appropriate column, a 0 otherwise. This control was not included in the test of hypothesis 1 or 2 due to the fact that the State pro-business rating independent variable is based upon geography, whereas there is no such variable in the test of hypothesis 3 , resulting in its inclusion as a control variable there.

\subsubsection{Hypotheses 4-8 Control Variables}

Financial slack. Since slack is made up of two components, financial slack and absorbed slack (Love \& Nohria, 2005), I wanted to ensure that my arguments apply to slack overall, and not just to absorbed slack. As a result, I controlled for financial slack to show how it responds differently to the agency influences I theorized. Following Kim et al. (2008), I calculated this variable as the ratio of quick assets (cash and marketable securities) to liabilities.

Firm size. I controlled for the size of each firm based on the number of employees of each firm obtained from the Compustat database.

Level of party influence. I controlled for firms making safer contributions to easier reelection campaigns versus those making riskier contributions in more competitive districts. This variable is based on the presidential vote in the district of the member of Congress receiving each contribution in the 2012 elections. I then subtracted that number from fifty, creating a variable where the farther away the vote average is from $50 \%$, the higher the party influence.

Urban population percentage. I controlled for the well-established geographical differences in political views based on whether the candidate receiving the contribution represents 
a more urban or more rural district (McKee \& Teigen, 2009). I calculated this variable from census data for the district of each member of Congress receiving contributions.

Party dummy. I controlled for the intense partisan divisions in Washington by identifying whether each member of Congress who received a contribution was a Democrat or a Republican. I scored contributions to Democrats and to Republicans with a 1 and a 0 , respectively.

Region dummy. Since political dynamics vary based on geography, I controlled for this factor with dummy variables for four of the five regions identified by McKee and Teigen (2009). For each of the regions, Midwest, Pacific, South and West, there is a 1 in the appropriate column, a 0 otherwise.

Industry division dummy. Since choice of industry is known to have a significant impact on a firm's performance (McGahan \& Porter, 1997), I controlled for this factor as well. The problem of controlling for industry, however, arises with the fact that I needed to control each industry with a dummy variable, and with this sample size, controlling for all industries would have dramatically increased my degrees of freedom. As a result, I controlled by SIC code industry division as defined by the United States Department of Labor Occupational Safety and Health Administration (United States Department of Labor, 2016), resulting in ten dummy variables.

\subsection{Empirical Strategy}

With this data, I ran separate regressions for each hypothesis. For hypothesis 1, my dependent variable was binary, thus I estimated using a logit model. I tested all other hypotheses using standard OLS regression. Since hypothesis 5 theorizes a mediation relationship, I followed the mediation test procedures outlined by Baron and Kenny (1986), combined with the Sobel (1982) test and bootstrapped confidence intervals to test the indirect effect of managerial discretion on CPA via absorbed slack. These procedures have been widely followed in the literature 
(Rodríguez \& Nieto, 2016). As a further test to build robustness for hypothesis 5, I used the structural equation modeling approach (Rodríguez \& Nieto, 2016) to compare the goodness of fit of the non-mediated model against the complete model, which includes the moderated mediation effect, also known as the conditional indirect effect (Sieger et al., 2013). 


\section{CHAPTER 5: RESULTS}

\subsection{Hypotheses 1-3}

Tables 2 and 3 display descriptive statistics and correlations for the variables used in this research. In neither table do I see any correlations in excess of 0.48 , with most having correlations substantially below that figure. As a result, it does not appear that there is an issue regarding multicollinearity among the independent variables.

Table 2 - Means, standard deviations, and correlations for Hypothesis 1 and 2 data

\begin{tabular}{|c|c|c|c|c|c|c|c|c|c|}
\hline Variable & $\mathrm{M}$ & SD & 1 & 2 & 3 & 4 & 5 & 6 & 7 \\
\hline 1. Vote on CR Omnibus & 0.51 & 0.50 & & & & & & & \\
\hline 2. Misc Business Contrib amt. & 0.00 & 1.00 & $\begin{array}{l}0.25 \\
0.00\end{array}$ & & & & & & \\
\hline 3. U.S. Chamber Rating & 0.00 & 1.00 & $\begin{array}{l}0.48 \\
0.00\end{array}$ & $\begin{array}{l}0.21 \\
0.00\end{array}$ & & & & & \\
\hline 4. State pro-business rating & 27.16 & 15.20 & $\begin{array}{r}-0.07 \\
0.14\end{array}$ & $\begin{array}{r}-0.02 \\
0.72\end{array}$ & $\begin{array}{r}-0.31 \\
0.00\end{array}$ & & & & \\
\hline 5. Level of Party influence & 0.00 & 1.00 & $\begin{array}{r}-0.23 \\
0.00\end{array}$ & $\begin{array}{r}-0.17 \\
0.00\end{array}$ & $\begin{array}{r}-0.22 \\
0.00\end{array}$ & $\begin{array}{l}0.05 \\
0.24\end{array}$ & & & \\
\hline 6. General election result & -0.54 & 1.61 & $\begin{array}{r}-0.10 \\
0.02\end{array}$ & $\begin{array}{r}-0.02 \\
0.58\end{array}$ & $\begin{array}{r}-0.01 \\
0.79\end{array}$ & $\begin{array}{r}-0.10 \\
0.02\end{array}$ & $\begin{array}{l}0.25 \\
0.00\end{array}$ & & \\
\hline 7. Incumbent dummy & 0.98 & 0.12 & $\begin{array}{l}0.03 \\
0.43\end{array}$ & $\begin{array}{l}0.01 \\
0.82\end{array}$ & $\begin{array}{l}0.06 \\
0.16\end{array}$ & $\begin{array}{l}0.01 \\
0.86\end{array}$ & $\begin{array}{r}-0.02 \\
0.66\end{array}$ & $\begin{array}{l}0.03 \\
0.49\end{array}$ & \\
\hline 8. Urban Pop. Percent & 0.00 & 1.00 & $\begin{array}{r}-0.22 \\
0.00 \\
\end{array}$ & $\begin{array}{r}-0.10 \\
0.02 \\
\end{array}$ & $\begin{array}{r}-0.42 \\
0.00 \\
\end{array}$ & $\begin{array}{l}0.12 \\
0.01\end{array}$ & $\begin{array}{l}0.06 \\
0.19 \\
\end{array}$ & $\begin{array}{l}0.00 \\
0.95 \\
\end{array}$ & $\begin{array}{r}-0.05 \\
0.25 \\
\end{array}$ \\
\hline
\end{tabular}

Note: Significance levels (p-values) in italics. $M$ and SD are used to represent mean and standard deviation, respectively. 
Table 3 - - Means, standard deviations, and correlations for Hypothesis 3 data

\begin{tabular}{|c|c|c|c|c|c|c|c|c|c|c|}
\hline Variable & $\mathrm{M}$ & SD & 1 & 2 & 3 & 4 & 5 & 6 & 7 & 8 \\
\hline 1. Club for Growth Rating & -0.01 & 1.01 & & & & & & & & \\
\hline 2. A.P.I. ad buys & 0.00 & 1.01 & $\begin{array}{c}-0.04 \\
0.71\end{array}$ & & & & & & & \\
\hline 3. General election result & -0.62 & 2.08 & $\begin{array}{l}0.24 \\
0.02\end{array}$ & $\begin{array}{c}-0.12 \\
0.24\end{array}$ & & & & & & \\
\hline 4. Urban Pop. Percent & 0.00 & 1.01 & $\begin{array}{r}-0.15 \\
0.14\end{array}$ & $\begin{array}{l}0.01 \\
0.94\end{array}$ & $\begin{array}{l}0.08 \\
0.45\end{array}$ & & & & & \\
\hline 5. Midwest region dummy & 0.19 & 0.40 & $\begin{array}{r}-0.02 \\
0.82\end{array}$ & $\begin{array}{l}0.04 \\
0.68\end{array}$ & $\begin{array}{c}-0.08 \\
0.43\end{array}$ & $\begin{array}{r}-0.14 \\
0.18\end{array}$ & & & & \\
\hline 6. West region dummy & 0.28 & 0.45 & $\begin{array}{l}0.23 \\
0.02\end{array}$ & $\begin{array}{c}-0.11 \\
0.29\end{array}$ & $\begin{array}{r}-0.11 \\
0.29\end{array}$ & $\begin{array}{l}0.00 \\
0.96\end{array}$ & $\begin{array}{r}-0.30 \\
0.00\end{array}$ & & & \\
\hline 7. South region dummy & 0.22 & 0.42 & $\begin{array}{l}0.31 \\
0.00\end{array}$ & $\begin{array}{l}0.06 \\
0.57\end{array}$ & $\begin{array}{r}-0.05 \\
0.59\end{array}$ & $\begin{array}{c}-0.16 \\
0.12\end{array}$ & $\begin{array}{c}-0.26 \\
0.01\end{array}$ & $\begin{array}{r}-0.33 \\
0.00\end{array}$ & & \\
\hline 8. Pacific region dummy & 0.08 & 0.28 & $\begin{array}{c}-0.28 \\
0.01\end{array}$ & $\begin{array}{c}-0.11 \\
0.30\end{array}$ & $\begin{array}{l}0.10 \\
0.35\end{array}$ & $\begin{array}{l}0.30 \\
0.00\end{array}$ & $\begin{array}{r}-0.15 \\
0.15\end{array}$ & $\begin{array}{r}-0.18 \\
0.07\end{array}$ & $\begin{array}{c}-0.16 \\
0.11\end{array}$ & \\
\hline 9. North region dummy & 0.22 & 0.42 & $\begin{array}{c}-0.35 \\
0.00\end{array}$ & $\begin{array}{l}0.09 \\
0.40\end{array}$ & $\begin{array}{l}0.18 \\
0.07\end{array}$ & $\begin{array}{l}0.10 \\
0.34\end{array}$ & $\begin{array}{c}-0.26 \\
0.01\end{array}$ & $\begin{array}{r}-0.33 \\
0.00\end{array}$ & $\begin{array}{c}-0.29 \\
0.00\end{array}$ & $\begin{array}{r}-0.16 \\
0.11\end{array}$ \\
\hline
\end{tabular}

Note: Significance levels (p-values) in italics. $M$ and $S D$ are used to represent mean and standard deviation, respectively.

I report in table 4 the beta coefficients for my OLS regressions of four models, in addition to the standard errors and statistical significance. In models 1 and 2, I test my first hypothesis, which predicts a statistically significant relationship between the policy supplier's position on an issue and the three factors of the political landscape. Using each supplier's vote on the CR Omnibus bill as my dependent variable, model 1 runs a logistic regression testing the controls only, while Model 2 tests the independent variables as well. Consistent with my expectations, I found statistically-significant relationships between the member of Congress's vote on the Continuing Resolution Omnibus budget bill and all three of the hypothesized elements of the political landscape: the supplier's relationships, as evidenced by the business contributions $(\beta=0.703, p=0)$; the supplier's ideology, demonstrated by the aggregate rating granted the member of Congress by 
the U.S. Chamber of Commerce $(\beta=1.083, p=0)$; and finally, the larger political trends impacting the supplier's district, as shown by the U.S. Chamber of Commerce Foundation's rating of the state's business favorability $(\beta=0.013, \mathrm{p}=0.069)$. Thus, I find support for my first hypothesis.

Models 3 and 4 report the tests of my second hypothesis, which predicts that business contributions will be negatively related to level of party influence, since those districts would be the ones where CPA will have less impact. Model 3 regresses the control variables only on my dependent variable, business campaign contributions to the policy supplier, while model 4 adds the independent variables. Again, the results support my hypothesis with a significant negative relationship between the level of business campaign contributions and the level of partisan influence in the supplier's constituency $(\beta=-0.173, \mathrm{p}=0)$. Importantly, the $\mathrm{R}^{2}$ I report for model 4 (0.039) is consistent with similar research (McKay, 2012). Thus, I also find support for my second hypothesis. 
Table 4 - Tests of Hypotheses 1 and 2

\begin{tabular}{|c|c|c|c|c|}
\hline & \multicolumn{2}{|c|}{$\begin{array}{c}\text { Vote for CR } \\
\text { Omnibus } \\
\text { logistic }\end{array}$} & \multicolumn{2}{|c|}{$\begin{array}{c}\text { Amount of Misc Business } \\
\text { Contributions } \\
\text { OLS }\end{array}$} \\
\hline & Model 1 & Model 2 & Model 3 & Model 4 \\
\hline Misc. Business Contribs Amt. & & $\begin{array}{c}0.703^{* * *} \\
(0.176)\end{array}$ & & \\
\hline U.S. Chamber Rating & & $\begin{array}{c}1.083^{* * *} \\
(0.128)\end{array}$ & & \\
\hline State pro-business rating & & $\begin{array}{c}0.013^{*} \\
(0.007)\end{array}$ & & \\
\hline Level of Party influence & & & & $\begin{array}{c}-0.173^{* * * *} \\
(0.044)\end{array}$ \\
\hline General election result & $\begin{array}{c}-0.134^{* *} \\
(0.057)\end{array}$ & $\begin{array}{c}-0.142^{* *} \\
(0.066)\end{array}$ & $\begin{array}{c}-0.015 \\
(0.027)\end{array}$ & $\begin{array}{c}0.011 \\
(0.028)\end{array}$ \\
\hline Incumbent dummy & $\begin{array}{c}0.465 \\
(0.761)\end{array}$ & $\begin{array}{c}0.051 \\
(0.985)\end{array}$ & $\begin{array}{c}0.046 \\
(0.356)\end{array}$ & $\begin{array}{c}0.013 \\
(0.352)\end{array}$ \\
\hline Urban Pop. Percent & $\begin{array}{c}-0.472^{* * *} \\
(0.094)\end{array}$ & $\begin{array}{l}-0.061 \\
(0.112)\end{array}$ & $\begin{array}{c}-0.101^{* *} \\
(0.044)\end{array}$ & $\begin{array}{c}-0.092^{* *} \\
(0.043)\end{array}$ \\
\hline Constant & $\begin{array}{c}-0.464 \\
(0.757)\end{array}$ & $\begin{array}{c}-0.372 \\
(1.000)\end{array}$ & $\begin{array}{c}-0.054 \\
(0.354)\end{array}$ & $\begin{array}{l}-0.006 \\
(0.350)\end{array}$ \\
\hline Observations & 525 & 525 & 525 & 525 \\
\hline$R^{2} /$ Pseudo $R^{2}$ & 0.045 & 0.223 & 0.011 & 0.039 \\
\hline
\end{tabular}

Finally, in table 5 I report the results of my tests of my third hypothesis, which predicts an inverse U-shaped relationship between a politician's ideology and the CPA firms engage in with that politician. In effect, I was predicting that CPA efforts would be aimed at the undecided, uncommitted policy suppliers who I assumed would be most persuadable to the business's policy position. In model 5, I test my dependent variable, the Club for Growth's rating of the policy supplier, in relation to my control variables. In model 6, I add into my test the independent variable, the ad buys by the American Petroleum Institute, and do not find a significant relationship $(\beta=0.009, \mathrm{p}=0.910)$. Finally, in model $7, \mathrm{I}$ add into my regression the square of the independent variable to test whether a quadratic relationship exists, and, as predicted, do find such a relationship 
$(\beta=-0.877, \mathrm{p}=0.004 ; \beta=0.926, \mathrm{p}=0.003)$. However, while a quadratic relationship clearly exists between the targets of the issue advertising and the Club for Growth rating for the suppliers, as I hypothesized, the nature of the curve is convex rather than concave. Thus, it appears that while an important relationship exists between these variables, it does not support hypothesis three.

Table 5 - Tests of Hypothesis 3

\begin{tabular}{lccc}
\hline & Model 5 & $\begin{array}{c}\text { Club for Growth Rating } \\
\text { Model 6 }\end{array}$ & Model 7 \\
\hline A.P.I. ad buys & & 0.009 & $-0.877^{* * *}$ \\
& & $(0.083)$ & $(0.296)$ \\
A.P.I. ad buys sq & & $0.926^{* * *}$ \\
& & & $(0.298)$ \\
General election result & $0.175^{* * *}$ & $0.176^{* * *}$ & $0.185^{* * *}$ \\
& $(0.040)$ & $(0.041)$ & $(0.039)$ \\
Urban Pop Percent & -0.020 & -0.021 & 0.009 \\
& $(0.086)$ & $(0.087)$ & $(0.084)$ \\
West region dummy & $0.425^{*}$ & $0.427^{*}$ & 0.243 \\
& $(0.241)$ & $(0.244)$ & $(0.240)$ \\
South region dummy & $0.602^{* *}$ & $0.601^{* *}$ & 0.332 \\
Pacific region dummy & $(0.251)$ & $(0.252)$ & $(0.256)$ \\
& $-1.037^{* * *}$ & $-1.032^{* * *}$ & $-1.357^{* * *}$ \\
North region dummy & $(0.357)$ & $(0.361)$ & $(0.360)$ \\
& $-0.781^{* * *}$ & $-0.782^{* * *}$ & $-1.085^{* * *}$ \\
Constant & $(0.257)$ & $(0.259)$ & $(0.266)$ \\
& 0.106 & 0.105 & 0.317 \\
\hline Observations & $(0.189)$ & $(0.190)$ & $(0.194)$ \\
$R^{2}$ & 98 & 98 & 98 \\
\hline Ne. Midwst regin & 0.405 & 0.463 \\
\hline
\end{tabular}

Note. Midwest region dummy is used as a base for region controls. Standard errors in parentheses ${ }^{*} p<0.10,{ }^{* *} p<0.05,{ }^{* * *} p<0.01$

\subsection{Hypotheses 4-7}

\subsubsection{Initial Results}

Table 6 displays descriptive statistics and correlations for the variables used in this research. Based on these results, there appears to be only one pair of independent variables displaying any level of collinearity: absorbed slack and managerial discretion $(\beta=0.58, p=0.00)$. 
This relationship is consistent with my theory predicting a direct relationship between absorbed slack and managerial discretion as part of my mediation hypothesis. To test for multicollinearity, I calculated the variance inflation factors (VIF) of all variables, excluding my industry controls. The mean VIF was 1.35, with the highest reaching 1.67, far below the conventional threshold of 10 (Oh et al., 2016). As a result, it does not appear that there is any issue regarding multicollinearity among the independent variables. 
Table 6 - Descriptive Statistics and Pairwise Correlations

\begin{tabular}{|c|c|c|c|c|c|c|c|c|c|c|c|c|}
\hline & Variable & $\mathrm{M}$ & SD & 1 & 2 & 3 & 4 & 5 & 6 & 7 & 8 & 9 \\
\hline 1 & $\mathrm{CPA}$ & 11.40 & 2.04 & & & & & & & & & \\
\hline 2 & Managerial Discretion & 0.00 & 1.00 & $\begin{array}{l}0.00 \\
0.70\end{array}$ & & & & & & & & \\
\hline 3 & Absorbed Slack & 0.00 & 1.00 & $\begin{array}{r}-0.04 \\
0.00\end{array}$ & $\begin{array}{l}0.58 \\
0.00\end{array}$ & & & & & & & \\
\hline 4 & Financial Slack & 0.00 & 1.00 & $\begin{array}{r}-0.03 \\
0.00\end{array}$ & $\begin{array}{l}0.07 \\
0.00\end{array}$ & $\begin{array}{l}0.12 \\
0.00\end{array}$ & & & & & & \\
\hline 5 & ROA & 0.00 & 1.00 & $\begin{array}{l}0.03 \\
0.00\end{array}$ & $\begin{array}{l}0.07 \\
0.00\end{array}$ & $\begin{array}{l}0.12 \\
0.00\end{array}$ & $\begin{array}{r}-0.06 \\
0.00\end{array}$ & & & & & \\
\hline 6 & Employees & 0.00 & 1.00 & $\begin{array}{l}0.04 \\
0.00\end{array}$ & $\begin{array}{l}0.07 \\
0.00\end{array}$ & $\begin{array}{l}0.02 \\
0.03\end{array}$ & $\begin{array}{r}-0.07 \\
0.00\end{array}$ & $\begin{array}{l}0.09 \\
0.00\end{array}$ & & & & \\
\hline 7 & Regulation & 0.00 & 1.00 & $\begin{array}{l}0.01 \\
0.20\end{array}$ & $\begin{array}{r}-0.30 \\
0.00\end{array}$ & $\begin{array}{r}-0.24 \\
0.00\end{array}$ & $\begin{array}{r}-0.11 \\
0.00\end{array}$ & $\begin{array}{r}-0.07 \\
0.00\end{array}$ & $\begin{array}{r}-0.15 \\
0.00\end{array}$ & & & \\
\hline 8 & Level of party influence & 0.00 & 1.00 & $\begin{array}{l}0.09 \\
0.00\end{array}$ & $\begin{array}{l}0.00 \\
0.87\end{array}$ & $\begin{array}{l}0.00 \\
0.70\end{array}$ & $\begin{array}{r}-0.01 \\
0.27\end{array}$ & $\begin{array}{l}0.00 \\
0.92\end{array}$ & $\begin{array}{l}0.00 \\
0.79\end{array}$ & $\begin{array}{r}-0.01 \\
0.29\end{array}$ & & \\
\hline 9 & Urban Population Percent & 0.00 & 1.00 & $\begin{array}{l}0.06 \\
0.00\end{array}$ & $\begin{array}{l}0.01 \\
0.29\end{array}$ & $\begin{array}{l}0.01 \\
0.21\end{array}$ & $\begin{array}{l}0.02 \\
0.06\end{array}$ & $\begin{array}{r}-0.01 \\
0.55\end{array}$ & $\begin{array}{l}0.00 \\
0.95\end{array}$ & $\begin{array}{r}-0.01 \\
0.36\end{array}$ & $\begin{array}{l}0.16 \\
0.00\end{array}$ & \\
\hline 10 & Party dummy (D=1) & 0.52 & 0.50 & $\begin{array}{l}0.28 \\
0.00\end{array}$ & $\begin{array}{l}0.02 \\
0.03\end{array}$ & $\begin{array}{l}0.01 \\
0.21\end{array}$ & $\begin{array}{l}0.00 \\
0.90\end{array}$ & $\begin{array}{l}0.00 \\
0.77\end{array}$ & $\begin{array}{l}0.00 \\
0.86\end{array}$ & $\begin{array}{r}-0.02 \\
0.09\end{array}$ & $\begin{array}{l}0.28 \\
0.00\end{array}$ & $\begin{array}{l}0.39 \\
0.00\end{array}$ \\
\hline
\end{tabular}
Note: Significance levels (p-values) in italics. $M$ and SD are used to repnesent mean and standard deviation, respectively. 
Table 7 - Regression Results Hypotheses 4-7

\begin{tabular}{|c|c|c|c|c|c|c|c|}
\hline & $\begin{array}{c}(1) \\
\text { CPA }\end{array}$ & $\begin{array}{c}\text { (2) } \\
\text { CPA }\end{array}$ & $\begin{array}{c}(3) \\
\text { Absorbed } \\
\text { Slack }\end{array}$ & $\begin{array}{c}\text { (4) } \\
\text { CPA }\end{array}$ & $\begin{array}{c}(5) \\
\text { Absorbed } \\
\text { Slack }\end{array}$ & $\begin{array}{c}(6) \\
\text { Absorbed } \\
\text { Slack }\end{array}$ & $\begin{array}{c}\text { (7) } \\
\text { ROA }\end{array}$ \\
\hline Managerial discretion & & $\begin{array}{c}-0.045^{* * *} \\
(0.009)\end{array}$ & $\begin{array}{c}0.568^{* * *} \\
(0.013)\end{array}$ & $\begin{array}{l}-0.013 \\
(0.011)\end{array}$ & $\begin{array}{c}0.558^{* * *} \\
(0.014)\end{array}$ & $\begin{array}{c}0.585^{* * *} \\
(0.014)\end{array}$ & \\
\hline Absorbed slack & & & & $\begin{array}{c}-0.057^{* * *} \\
(0.010)\end{array}$ & & & \\
\hline Regulation & & & & & $\begin{array}{c}-0.029^{* * *} \\
(0.011)\end{array}$ & $\begin{array}{c}-0.056^{* * *} \\
(0.012)\end{array}$ & \\
\hline Man. discretion $\mathrm{x}$ regulation & & & & & & $\begin{array}{c}-0.071^{* * * *} \\
(0.012)\end{array}$ & \\
\hline CPA & & & & & & & $\begin{array}{l}0.035^{* *} \\
(0.017)\end{array}$ \\
\hline Financial slack & $\begin{array}{c}-0.018^{* *} \\
(0.009)\end{array}$ & $\begin{array}{l}-0.015^{*} \\
(0.009)\end{array}$ & $\begin{array}{c}0.133^{* * *} \\
(0.012)\end{array}$ & $\begin{array}{l}-0.008 \\
(0.009)\end{array}$ & $\begin{array}{c}0.131^{* * *} \\
(0.012)\end{array}$ & $\begin{array}{c}0.131^{* * *} \\
(0.012)\end{array}$ & $\begin{array}{l}0.026^{* *} \\
(0.011)\end{array}$ \\
\hline Firm size & $\begin{array}{c}0.043^{* * *} \\
(0.008)\end{array}$ & $\begin{array}{c}0.044^{* * *} \\
(0.008)\end{array}$ & $\begin{array}{c}-0.029^{* * *} \\
(0.011)\end{array}$ & $\begin{array}{l}0.043^{* * *} \\
(0.008)\end{array}$ & $\begin{array}{c}-0.031^{* * *} \\
(0.011)\end{array}$ & $\begin{array}{c}-0.027^{* *} \\
(0.011)\end{array}$ & $\begin{array}{c}0.015 \\
(0.010)\end{array}$ \\
\hline Level of party influence & $\begin{array}{l}-0.002 \\
(0.007)\end{array}$ & $\begin{array}{c}-0.002 \\
(0.007)\end{array}$ & $\begin{array}{c}0.001 \\
(0.010)\end{array}$ & $\begin{array}{l}-0.002 \\
(0.007)\end{array}$ & $\begin{array}{c}0.001 \\
(0.010)\end{array}$ & $\begin{array}{c}0.001 \\
(0.010)\end{array}$ & $\begin{array}{c}0.001 \\
(0.009)\end{array}$ \\
\hline Urban population percent & $\begin{array}{l}-0.008 \\
(0.008)\end{array}$ & $\begin{array}{l}-0.008 \\
(0.008)\end{array}$ & $\begin{array}{l}-0.003 \\
(0.011)\end{array}$ & $\begin{array}{l}-0.008 \\
(0.008)\end{array}$ & $\begin{array}{l}-0.003 \\
(0.011)\end{array}$ & $\begin{array}{l}-0.003 \\
(0.011)\end{array}$ & $\begin{array}{c}0.000 \\
(0.010)\end{array}$ \\
\hline Party dummy $(\mathrm{D}=1)$ & $\begin{array}{c}0.368^{* * *} \\
(0.018)\end{array}$ & $\begin{array}{c}0.369^{* * *} \\
(0.018)\end{array}$ & $\begin{array}{c}0.038 \\
(0.024)\end{array}$ & $\begin{array}{c}0.371^{* * *} \\
(0.018)\end{array}$ & $\begin{array}{c}0.037 \\
(0.024)\end{array}$ & $\begin{array}{c}0.036 \\
(0.024)\end{array}$ & $\begin{array}{l}-0.026 \\
(0.023)\end{array}$ \\
\hline Region dummy & Included & Included & Included & Included & Included & Included & Included \\
\hline Industry division dummy & Included & Included & Included & Included & Included & Included & Included \\
\hline Constant & $\begin{array}{c}12.399^{* * *} \\
(0.103) \\
\end{array}$ & $\begin{array}{c}12.424^{* * *} \\
(0.103) \\
\end{array}$ & $\begin{array}{c}0.556^{* * *} \\
(0.143) \\
\end{array}$ & $\begin{array}{c}12.456^{* * *} \\
(0.103) \\
\end{array}$ & $\begin{array}{l}0.539^{* * *} \\
(0.143) \\
\end{array}$ & $\begin{array}{c}0.478^{* * *} \\
(0.143) \\
\end{array}$ & $\begin{array}{l}0.600^{* *} \\
(0.244) \\
\end{array}$ \\
\hline $\begin{array}{l}\text { Observations } \\
R^{2}\end{array}$ & $\begin{array}{l}5,527 \\
0.098\end{array}$ & $\begin{array}{l}5,527 \\
0.102\end{array}$ & $\begin{array}{l}5,527 \\
0.404\end{array}$ & $\begin{array}{l}5,527 \\
0.108\end{array}$ & $\begin{array}{l}5,527 \\
0.405\end{array}$ & $\begin{array}{l}5,527 \\
0.409\end{array}$ & $\begin{array}{l}5,527 \\
0.224\end{array}$ \\
\hline
\end{tabular}

Note: Standard errors in parentheses.

${ }^{*} p<0.10,{ }^{* *} p<0.05,{ }^{* * *} p<0.01$

In Table 7, I report the beta coefficients for OLS regressions of seven models, in addition to standard errors and statistical significance. Model 8 is the baseline model, which includes only the control variables. As shown in model 8, several of the controls reveal a statistically significant relationship with the dependent variable: firm size $(\beta=0.043, p<0.01)$, the party dummy $(\beta=$ $0.368, p<0.01)$, and financial slack $(\beta=-0.018, p<0.05)$. Larger firms, for example, likely have more people monitoring the activities of the managers, thus reducing the likelihood that top managers will be able to engage in opportunistic CPA. Thus, the result regarding firm size has a sound theoretical basis. Similarly, given the expectation that top executives will lean toward 
Republican in their personal political views (Adams \& Hardwick, 1998), it makes sense that CPA aimed to benefit their personal agenda will tend to favor Republican candidates, while managers who prioritize the interests of the shareholders will engage in a more balanced approach to making political contributions. Finally, I predicted that absorbed slack will have a higher impact on the ability for managers to behave opportunistically than financial slack, since the ready availability of financial slack in the form of cash and short-term investments will make financial slack a target for shareholders seeking dividends or other measures aimed at increasing short-term shareholder value. Thus, while I expect that all slack, including financial slack, can lead to opportunism (see also Huang \& $\mathrm{Li}, 2012$ ), the greater relative importance of absorbed slack should make financial slack insignificant on its inclusion in the regression. Therefore, it is not surprising that models excluding absorbed slack, including model 8, would show a significant and negative relationship to CPA directed to benefit the shareholders. Thus, it appears the results meet expectations.

In model 9, I test the first hypothesis, which predicts a statistically significant negative relationship between managerial discretion and whether the firms focus their CPA efforts on benefiting the shareholders. The regression result supported the predicted negative relationship ( $\beta$ $=-0.045, p<0.01$, model 2) between managerial discretion and CPA aimed at benefiting shareholders. Thus, I find support for hypothesis 4.

Hypothesis 5 predicted a relationship in which absorbed slack would mediate the relationship between managerial discretion and the firm engaging in CPA aimed at advancing the shareholders' interests. I test this prediction by following the guidance of Baron and Kenny (1986) (see Currim, Lim, \& Kim, 2012; Ellis, Aharonson, Drori, \& Shapira, 2017; Shan, Fu, \& Zheng, 2017; Sieger et al., 2013). According to Baron and Kenny (1986), the mediation effect occurs when the (significant) effect that the independent variable has on the dependent variable becomes 
less with the inclusion of the mediator variable in the model under the condition that a significant relation exists between the independent variable and the mediator variable and also between the mediator variable and the dependent variable. The first step of the Baron and Kenny (1986) test is to regress the independent variable on the dependent variable (Rodríguez \& Nieto, 2016). In model 9, I find a negative and significant relationship between my independent variable, managerial discretion, and my dependent variable, CPA, focused on the interests of the shareholders $(\beta=-0.045, p<0.01)$. The second step is to regress the independent variable on the mediator (Rodríguez \& Nieto, 2016). Following that direction, in model 10, I find significant and positive relationships between managerial discretion and the mediator, absorbed slack $(\beta=0.568$, $p<0.01)$. The third step of the test is to regress the mediator and the independent variable on the dependent variable (Rodríguez \& Nieto, 2016). In model 11, I find significant and negative relationships between absorbed slack, my mediator, and my dependent variable $(\beta=-0.057, p<$ 0.01). Furthermore, it is worth noting that managerial discretion became nonsignificant once absorbed slack was included in the regression. This finding fully supports the mediated relationship (Baron \& Kenny, 1986; Zhao, Lynch, \& Chen, 2010). Finally, I calculate the Sobel mediation test (Currim et al., 2012), which resulted in a z statistic of $-4.49(p<0.01)$, while the Goodman and Aroian tests also show significance at the $p<0.01$ level (Ellis et al., 2017). These findings together confirm the mediation relationship predicted in hypothesis 5 .

The above test is considered a conservative approach to testing for mediation (Currim et al., 2012). Despite this fact, following the preferred approach in recent business research, I also calculated a bootstrapped model (Bear, Rahman, \& Post, 2010; Ellis et al., 2017; Preacher \& Hayes, 2004; Zhao et al., 2010). With 5,000 iterations, this technique returned a $\mathrm{z}$ statistic of -4.44 $(p<0.01)$ with a $95 \%$ confidence interval of $(-0.039,-.015)$, which does not include zero, thus 
further supporting my mediation hypothesis (Liao, Wayne, Liden, \& Meuser, 2017; Zhao et al., 2010).

My sixth hypothesis predicted that industry regulation would negatively moderate the relationship between managerial discretion and absorbed slack. Specifically, my theory suggests that the positive effect of managerial discretion on absorbed slack would be lower for firms in the industry where regulatory pressure is high. I test this prediction in models 12 and 13 by regressing absorbed slack on industry regulation, managerial discretion, and an interaction variable between the two variables. In model 12 , industry regulation is negatively related to absorbed slack $(\beta=$ $0.029, p<0.01$ ), while managerial discretion is strongly and positively related to absorbed slack $(\beta=0.558, p<0.01)$. These findings suggest that absorbed slack would be lower where there is higher regulation, and that higher managerial discretion allows managers to direct resources into absorbed slack. In model 13, I added the interaction variable between the managerial discretion and regulation to model 12. As shown in model 13, the interaction variable is negative and significant $(\beta=-0.071, p<0.01)$, which confirms hypothesis 6 . The interaction plot in figure 4 also shows that the positive relationship between managerial discretion and absorbed slack becomes less positive under high industry regulation. As a result, I find strong support for my sixth hypothesis as well. 
Figure 4 - Moderation Effect of Industry Regulation

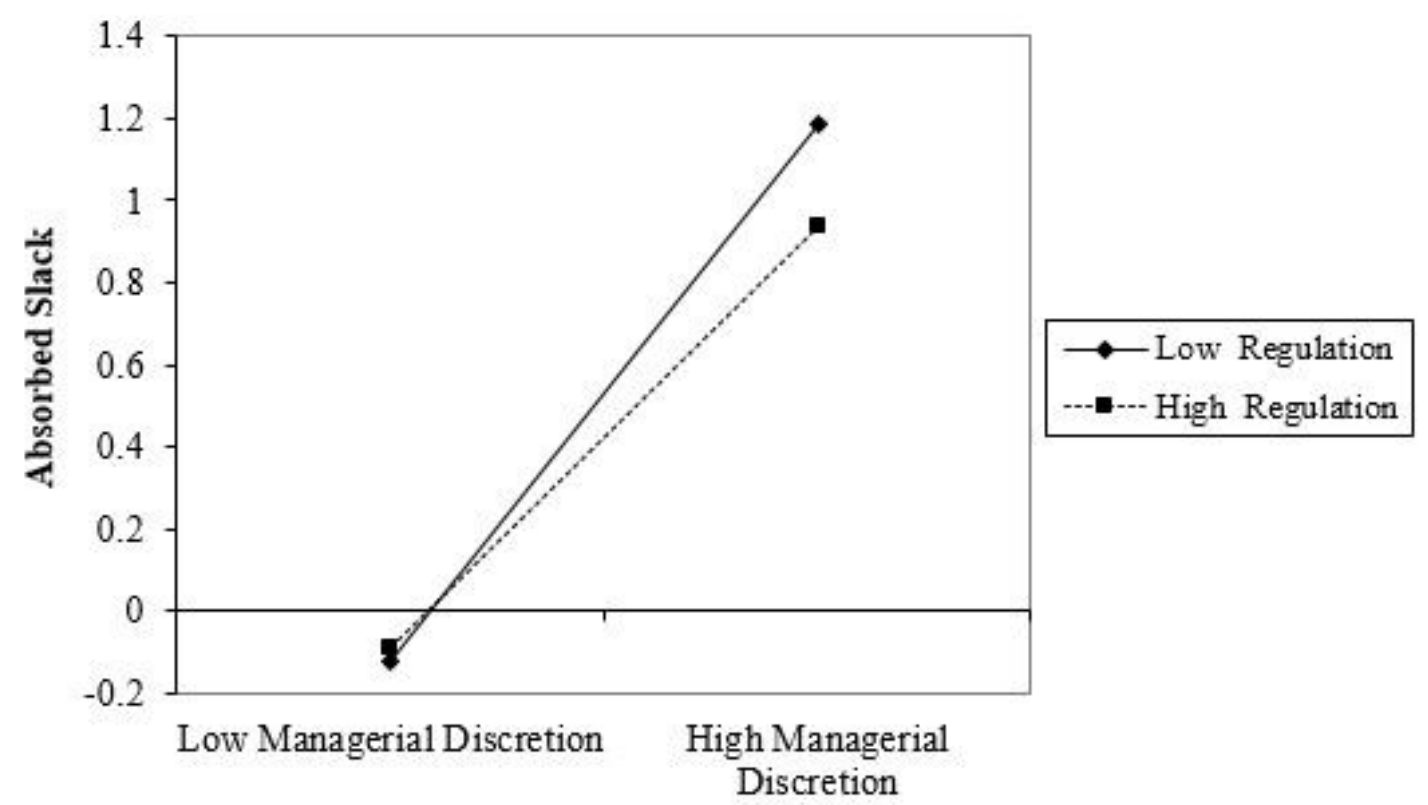

Finally, in model 14, I present the results of regression for hypothesis 7, which predicted a positive relationship between firm performance (ROA) and CPA focused on the interests of shareholders. As shown in model 14, I find the predicted positive relationship between ROA and CPA $(\beta=0.035, p<0.05)$. Hypothesis 7 is thus confirmed.

It is worth noting that since I specified my dependent variable using its natural log, the coefficients of the independent variables represent a percentage change in the level of a firm's orientation toward CPA aimed at benefiting shareholders (Flammer, 2018). Furthermore, since the independent variables are all standardized, a change of one represents a change of one standard deviation. Thus, the regression coefficient of -0.045 for the managerial discretion variable (model 2) indicates that $1 \%$ reduction in the standard deviation of a firm's managerial discretion would increase CPA activity aimed to benefit the shareholders by $4.5 \%$. Similarly, the regression coefficient of 0.035 for the CPA variable (model 7) suggests that a $1 \%$ increase in the standard deviation of a firm's focus on CPA aimed to benefit the shareholders would be associated with an increase in ROA by 3.5\%. Consequently, based on my regression findings, I estimate that for the 
median firm in my sample with $\$ 35,471,000$ in assets, this $1 \%$ increase in the firm's CPA focus would result in an estimated increase of net income of $\$ 183,399$.

\subsubsection{Additional and Robustness Tests}

I performed additional structural equation modeling (SEM) analysis to build robustness in my findings. For SEM analysis, I proposed two models: one model without a path between absorbed slack and the variable representing CPA focused on the shareholders' interests, and the other model with that path added in. In effect, the first model is not mediated, while the second is my complete model including the moderated mediation. Consistent with regression results in Table 7, the unmediated SEM model shows a significant and negative relationship between managerial discretion and CPA $(\beta=-0.037, p<0.01)$. Once the mediation path is added in, however, the relationship between managerial slack and CPA becomes nonsignificant $(\beta=0.009, p=0.562)$, and the relationship between absorbed slack and CPA aimed at benefiting the shareholders becomes negative and significant $(\beta=-0.079, p<0.01)$, supporting the prior results which suggested a fully mediated model. The best model fit (RMSEA 0.043, CFI 0.961) occurred when I included the link between absorbed slack and CPA focused on the shareholders' interests. Furthermore, the $\chi^{2}$ difference between the two models is significant $\left(\Delta \chi^{2}=24.88,1\right.$ degree of freedom, $p<0.01$ ) (Ramarajan, Rothbard, \& Wilk, 2017), and the Akaike information criterion (AIC), for which lower values reflect the better-fitting model (Kunze, de Jong, \& Bruch, 2016), also supports this conclusion $(\mathrm{AIC}=132,139.8$ for the nonmediated model; $\mathrm{AIC}=132,116.9$ for the complete model), providing further support for a mediated model as predicted in hypothesis 5. 
Figure 5 - SEM Results

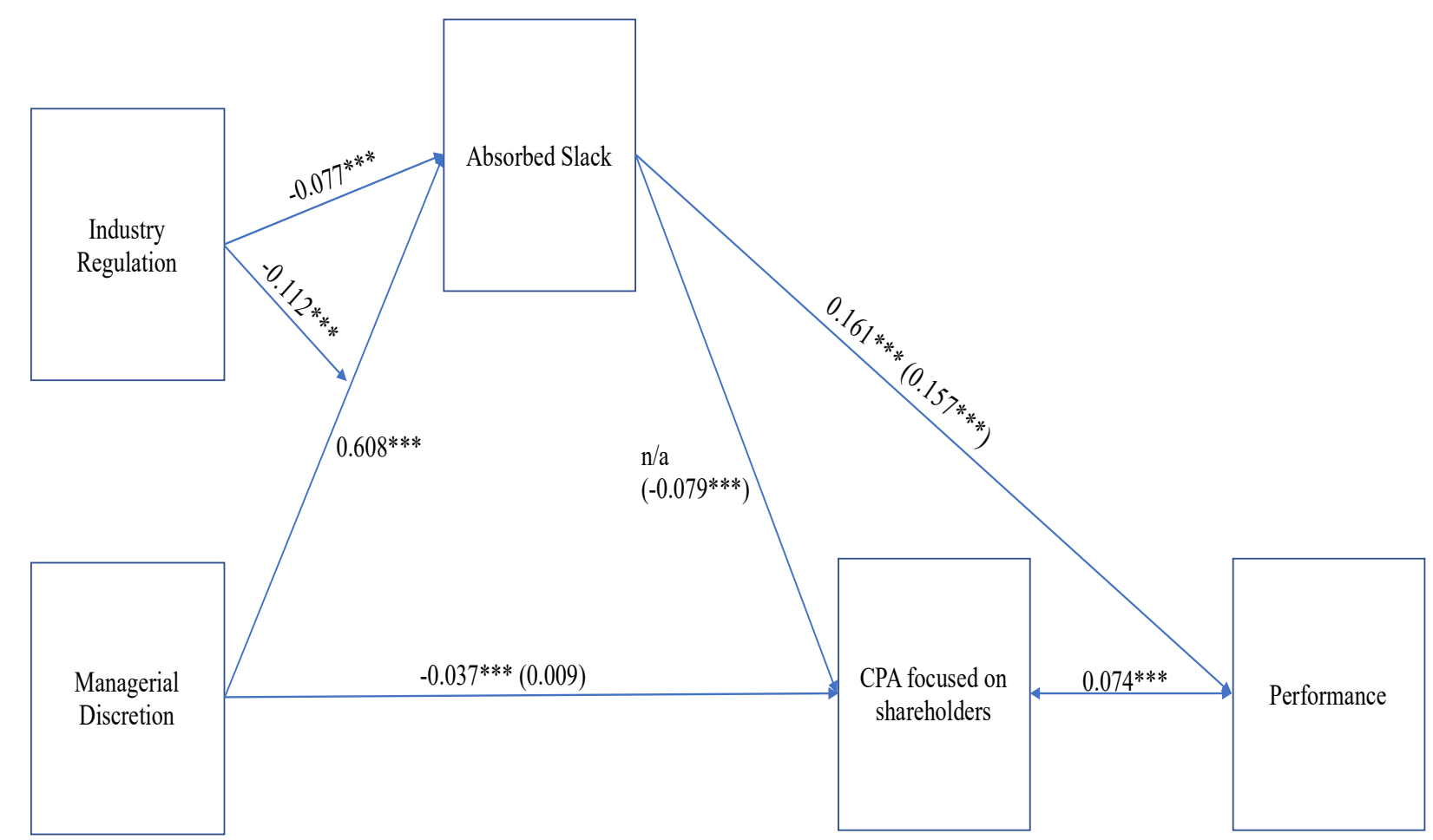

Standardized path coefficients for SEM model without path from absorbed slack to CPA

Parentheses: Standardized path coefficients for mediated SEM model with path added in from absorbed slack to CPA (if different)

$p>\mathrm{X} 2 \quad 0.00(0.00)$

RMSEA $\quad 0.05(0.04)$

CFI $\quad 0.95(0.96)$

$* p<0.10, * * p<0.05, * * * p<0.01$

RMSEA: root mean square error of approximation, CFI: comparative fit index

Note: path from CPA to performance is a correlation, since the variables impact each other.

Controls included: employees, party influence, urban population percent, party dummy. 


\section{CHAPTER 6: DISCUSSION AND CONCLUSION}

\subsection{Hypotheses 1-3}

In this research, I proposed and tested three hypotheses aimed at better explaining how firms engage in CPA. My first hypothesis tested a model in which the CPA efforts of policy demanders will be associated with the policy suppliers' (a) ideology (b) political trends in their constituency that might make an issue salient and (c) their personal relationships. I find support for this model, suggesting that there are these institutional constraints that both limit the effectiveness of CPA while also suggesting where firms should aim their CPA efforts. Second, I hypothesize that political parties will be a force capable of moderating the impact of CPA. In essence, where political parties are strong, they will be able to brunt the impact of efforts by policy demanders to pressure the policy suppliers to adopt a specific position. Thus, the presence of strong political parties weakens the strength of CPA. I find strong support for this hypothesis as well, again potentially guiding practitioners in targeting their CPA, while also helping scholars understand the relative success or failure of specific CPA campaigns. Finally, I predict that firms will prioritize CPA aimed at policy suppliers located in the middle of the ideological spectrum, assuming that these individuals will be undecided on the policy demanders' requests, and thus will be most persuadable. The result of this test, however, is surprising, indicating that while there is a quadratic relationship as I hypothesized, the policy demanders actually target their CPA toward policy demanders whose ideology places them at one extreme or another, rather than those located in the middle. This result in particular raises concerns that I will discuss further in my implications section.

\subsubsection{Implications}

Reviewing the results of the research, there are a number of conclusions one can draw. 
First of all, there is strong support for two of my three hypotheses. Indeed, the weakest support for my predictions appears to be the relatively weak relationship between the third factor of my political landscape, the constituency's political trends as represented by the state's pro-business rating, and the vote on the $\mathrm{CR}$ Omnibus bill $(\beta=0.013, \mathrm{p}=0.069)$. This relatively weak result might have two explanations. First, while the level of the policy supplier's pro-business ideology and pro-business connections might play a large role in each of those two elements of the landscape, the state's pro-business orientation in the supplier's constituency is probably a small factor of that element. For example, there might be influence based upon the advocacy of the President, the state's governor, and other political leaders. The regional news media might have impacted the views of the regional electorate, and the high level of partisanship in modern American political culture might also have impacted the political trends of the supplier's district. Thus, the variable I used to test this element of the landscape makes up a far smaller portion of that element than the variables I used to test the other two. Secondly, this variable is statewide, while the bulk of my sample is divided into districts. The U.S. Chamber of Commerce Foundation's rankings are by state, and 428 of the 536 members of Congress included in my sample are members of the House of Representatives, often representing small parts of larger states. Thus, the U.S. Chamber Foundation ranks New York as the worst state in the nation for business. Overall, the state's population might share a view that is more friendly to regulation than most other states. However, the constituents in districts in upper New York state, mostly represented by Republican members of the House, likely have very different views from those representing New York City. As a result, a more precise measurement of the political trends in each congressional district might find stronger support.

One surprise in the data is the apparent relative unimportance of incumbency to CPA 
efforts. It has long been assumed that incumbency is a strong predictor of campaign contributions and other political advantages (Benoit \& Marsh, 2008; Cox \& Katz, 1996; Perry \& McWhirter, 2010). Such a relationship, however, was not evident in my results. For example, I did not find a significant relationship between incumbency and the policy supplier's issue position (models 1 and 2) or the amount of contributions the candidate received from the business community (models 3 and 4). This result could simply represent a statistical anomaly due to the fact that there are so few non-incumbents who get elected to Congress in any given year. In fact, in my data, only 9 of 525 members of Congress elected in 2014 were not incumbents. That said, controlling for the effect of incumbency was critical given the importance so many have placed upon it in the political process. Thus, while my results raise a question on this point, it is likely a question that will require further research.

Finally, the unexpected result regarding hypothesis 3 seems to say much about the current American political climate that businesses must negotiate. Rather than focusing their efforts on the persuadable middle group of policy suppliers, demanders are focusing their efforts on the extremes. Thus it appears that policy demanders are attempting to reward their political friends and punish their enemies rather than establishing the long-term relationships with policy suppliers that will produce the greatest return for the firm. This result could be a function of the deep divisions in my current political culture, and the reduced influence of moderate politicians. In effect, it appears that business leaders are making common cause with the activists on the political extremes to push a specific political agenda rather than building a broad coalition in support of the business's interests. Why business leaders have taken this approach and whether it bears fruit for the firms might be a subject for future research, however this result might help explain the weak link prior research has found between CPA efforts and firm performance (see e.g. Hadani \& 
Schuler, 2013).

\subsection{Hypotheses 4-7}

\subsubsection{Review of Results}

Hypotheses proposed in this paper theorizing an agency view of firms' approach to CPA found support. The fourth hypothesis predicted a negative relationship between the dependent variable - firms' CPA focused on the interests of the shareholders and managerial discretion. The predicted relationship was confirmed, which supports the theory that where managers have the potential to behave opportunistically with the greater decision-making power, they will do so by taking advantage of the firm's resources to pursue a personal political agenda rather than one aimed at advancing the firm's policy agenda. Firms engaging in CPA aimed primarily at promoting the firm's interests will direct their efforts at building a majority coalition to support the policy priorities of the firm. To do so, the firm's managers will have to add to the base of support they already enjoy among policymakers with undecided legislators from the ideological middle until they have achieved their majority. In effect, these managers will be forced to behave as stewards of the firm rather than as agents due to the lack of opportunism. On the other hand, where top managers can behave opportunistically, they would prioritize rewarding their political friends and punish their ideological opponents rather than building a broad coalition of supporters among policymakers for the firm's priorities. Thus, I find that where managerial discretion exists that would enable top managers to behave opportunistically, they will use the firm's assets to pursue their own personal political priorities rather than those that benefit the firm.

In hypothesis 5, I predicted a relationship in which absorbed slack would mediate the relationship between managerial discretion and CPA aimed at benefiting the shareholders such that where there is higher absorbed slack, managers would be more likely to use corporate funds 
to pursue their own personal political agenda. One interesting point to come from this analysis is the lack of a link between financial slack and CPA when the absorbed slack is accounted for. This result might help explain why prior research has been unable to find a link between slack and CPA (Hillman et al., 2004; Lenway \& Rehbein, 1991; Schuler et al., 2002). In effect, the two forms of slack needed to be split to demonstrate the relationship. Following my theory, it appears that managers will be restricted from pursuing CPA aimed at their own personal political agenda when slack is fully visible on the firm's financial reports, as is the case with financial slack, unlike with absorbed slack. Thus, my results support hypothesis 5 as well.

In hypothesis 6 , I predicted that industry regulation would moderate the relationship between managerial discretion and absorbed slack such that where managerial discretion is high, higher regulation would restrict the managers from moving resources into absorbed slack. Higher industry regulation has been linked to lower managerial discretion (Finkelstein \& Hambrick, 1990). This finding is the basis for my argument, and it is relevant to the overall question regarding CPA, since I found that lower absorbed slack is linked to CPA more focused on the interests of shareholders. Thus, in effect, higher regulation will push managers to engage in CPA benefiting the firm by restricting the strategic options (Pugliese, Minichilli, \& Zattoni, 2014: 1191) and thereby reducing the discretion of managers to build resources as absorbed slack. Furthermore, it is worth noting that firms operating in more-regulated environments likely have an additional motivation to engage in moderate ideology-oriented CPA: these firms must build support for their firm and avoid making enemies among policymakers, since these individuals could have a direct and measurable impact on the firms' success. If these firms pursue a strategy of punishing political enemies, this strategy will not only fail to add new friends to the firms' political coalition, it will actually harden the animus of the firms' opponents. Thus, there will be pressure from multiple 
directions pushing firms in highly regulated industries to target their CPA at the moderate middle politicians rather than the ideological extremes, and my data support this conclusion.

Finally, I also find support for my seventh hypothesis, which predicted that the bestperforming firms will engage in CPA aimed at furthering the interests of the shareholders rather than pursuing the managers' personal political agenda. This result makes sense in that effective CPA can positively impact firm performance, as I have shown above. However, if I accept the inference of agency theory that opportunism on the part of top managers will negatively impact the interests of the shareholders, then CPA engaged in opportunistic pursuit of top managers' personal interests will be a characteristic of poorer-performing firms. Either way, this final hypothesis also receives support.

My research contributes to the literature in three ways. First, I provide an answer to a question that has vexed scholars: explaining why firms engage in CPA in the first place. For some time, scholars have struggled with this question, particularly in light of findings that there was no relationship between CPA and firm performance (Hadani, Bonardi, \& Dahan, 2017; Hadani \& Schuler, 2013). In effect, I have alluded that CPA needs to be divided into two groups, each with its own motivation. On the one hand are firms where the managers do not behave opportunistically and direct their CPA toward moderate policymakers to build support for their firms' priorities. On the other hand are firms where top managers do behave opportunistically and use the firms' resources in support of their own personal political agenda. The support my hypotheses receive demonstrates the feasibility of my explanation. Second, prior research into CPA has been dominated by a stewardship perspective, in which scholars assume managers engage in these efforts primarily for the benefit of their firms (Hadani et al., 2015). This approach has been justified by a view of agency theory that opportunism results primarily from economic motives (Bosse \& 
Phillips, 2016). In effect, in the past, managers were viewed as purely motivated by economic incentives, such as stock options, or fear of consequences resulting from greater monitoring of their activity (Eisenhardt, 1989). Empirical research aimed at supporting this view of managers, such as tests of the effectiveness of stock options, has not been favorable (Dalton et al., 2003). In response, recent research has attempted to add nuance to agency theory, by suggesting that the motives of managers are actually more complex, and that these complexities need to be considered by principals as they attempt to address potential opportunism (Pepper \& Gore, 2015). Thus, my research follows this "behavioral" approach to agency theory, since I argue that opportunism can result from ideological motives as well as financial ones. While this insight is not unique to this study, prior research attempting to validate this idea has been largely inconclusive (Hadani et al., 2015). Finally, the link between slack and nonmarket strategies such as CPA and corporate social responsibility (CSR) has been widely theorized, but empirical results have been mixed, with some studies supporting the link, others failing to find one (Hillman et al., 2004; Schuler et al., 2002; Tan \& Peng, 2003; Xu, Yang, Quan, \& Lu, 2015). By specifically testing the two forms of slack, I offer an additional test of the relationship in the context of CPA.

\subsubsection{Limitations of This Research}

One of the limitations of this research is that it is very U.S.-oriented. I make no claim that this theory is directly transferable to other countries. Even so, researching American CPA is critical given the importance of the U.S. economy and political structure on the rest of the world. Furthermore, I believe it is likely that even where this theory cannot be applied in its entirety, an approach that considers behavior based in power dynamics such as this one has better explanatory power than a purely market-based one. In this way, this theory might serve as a model for similar research in other countries. 
A further limitation is that the data only include publicly traded corporations that engage in CPA, while not considering privately held firms. Indeed, especially given the importance family firms play in stewardship theory research (Chrisman et al., 2007), it might be interesting to see if family firms engage differently in CPA. Prior research has found that family firms tend to be driven by the owners' ideological views (Hart, 2004). On the other hand, research has also found that family firms tend to respond strongly to the demands of outside investors, who may have different ideological perspectives than the family owners (Miller, Breton-Miller, \& Lester, 2013). Thus, it remains an open question as to whether family firms will be a vehicle for the family to engage in ideologically driven CPA or will focus on CPA that benefits the firm.

\subsection{Conclusion}

Research into CPA can be a particularly exciting area due to its importance to scholarship as well as in practice. This research can impact research into non-market strategies overall, as well as agency theory and institutional theory. Furthermore, basic research such as this can provide evidence both sides can use as they debate the political impact of business in the wake of the Citizens' United Supreme Court case. As a result, it is my hope that this paper will be useful to many different groups in many different contexts. 


\section{REFERENCES}

Adams, M., \& Hardwick, P. 1998. An analysis of corporate donations: United Kingdom evidence. Journal of Management Studies, 35(5): 641-654.

Admati, A., \& Hellwig, M. 2013. The Bankers' New Clothes: What's Wrong with Banking and What to Do About It. Princeton: Princeton University Press.

Aggarwal, R. K., Rajesh, K. A., Felix, M., \& Tracy Yue, W. 2012. Corporate Political Donations: Investment or Agency? Business and politics, 14(1): 1-38.

Aguilera, R. V., Filatotchev, I., Gospel, H., \& Jackson, G. 2008. An Organizational Approach to Comparative Corporate Governance: Costs, Contingencies, and Complementarities. Organization Science, 19(3): 475-492.

Al-Ubaydli, O. A., \& McLaughlin, P. 2014. A Numerical Database on Industry-specific Regulations for All U.S. Industries and Federal Regulations. http://mercatus.org/publication/regdata-numerical-database-industry-specific-regulations, Arlington, VA: George Mason University.

Aldrich, H. E., \& Fiol, C. M. 1994. Fools rush in: The institutional context of industry creation. Academy of Management Review, 19(4): 645-670.

Alexander, D. 2014. Billionaires Tom Steyer, Michael Bloomberg Are Top Disclosing Political Donors In America, Forbes.

Alt, J. E., Lassen, D. D., \& Marshall, J. 2016. Credible Sources and Sophisticated Voters: When Does New Information Induce Economic Voting? Journal of Politics, 78(2): 327-342. American Petroleum Institute. 2018. About API. http://www.api.org/about, first accessed May 2018. 
Amit, R., Brander, J., \& Zott, C. 1998. Why do venture capital firms exist? Theory and Canadian evidence. Journal of Business Venturing, 13(6): 441-466.

Anderson, M., Asdemir, O., \& Tripathy, A. 2013. Use of precedent and antecedent information in strategic cost management. Journal of Business Research, 66(5): 643-650.

Ansolabehere, S., Hansen, J. M., Hirano, S., \& Snyder, J. M. 2007. The Decline of Competition in U.S. Primary Elections, 1908-2004. In M. P. McDonald, \& J. Samples (Eds.), The Marketplace of Democracy: Electoral Competition and American Politics: 74-101. Washington: Brookings Institution Press.

Apollonio, D. E., \& La Raja, R. J. 2004. Who gave soft money? The effect of interest group resources on political contributions. Journal of Politics, 66(4): 1134-1154.

Aronoff, K. 2015. Some Unions Think Supporting Keystone XL Was A Mistake. https://news.vice.com/article/some-unions-think-supporting-keystone-xl-was-a-mistake, first accessed February 12, 2017.

Baer, D., \& Hartmann, H. 2014. Building Women's Political Careers: Strengthening the Pipeline to Higher Office. Washington, D.C.: Institute for Women's Policy Research.

Bafumi, J., \& Shapiro, R. Y. 2009. A New Partisan Voter. Journal of Politics, 71(1): 1-24.

Barley, S. R., \& Tolbert, P. S. 1997. Institutionalization and structuration: studying the links between action and institution. Organization Studies, 18: 93+.

Baron, D. 1995. The Nonmarket Strategy System. MIT Sloan Management Review, 37(1): 7385.

Baron, R. A. 1998. Cognitive mechanisms in entrepreneurship: Why and when enterpreneurs think differently than other people. Journal of Business Venturing, 13(4): 275-294. 
Baron, R. M., \& Kenny, D. A. 1986. The moderator-mediator variable distinction in social psychological research: conceptual, strategic, and statistical considerations. Journal of personality and social psychology, 51(6): 1173-1182.

Bear, S., Rahman, N., \& Post, C. 2010. The Impact of Board Diversity and Gender Composition on Corporate Social Responsibility and Firm Reputation. Journal of Business Ethics, 97(2): 207-221.

Bebchuk, L. A., \& Jackson, R. J., Jr. 2010. Corporate political speech: who decides?, Harvard Law Review, Vol. 124: 83+.

Benoit, K., \& Marsh, M. 2008. The campaign value of incumbency: A new solution to the puzzle of less effective incumbent spending. American Journal of Political Science, 52(4): 874890.

Blinder, A. S. 2013. After the Music Stopped: The Financial Crisis, the Response, and the Work Ahead. New York: The Penguin Press.

Blinder, S., Ford, R., \& Ivarsflaten, E. 2013. The Better Angels of Our Nature: How the Antiprejudice Norm Affects Policy and Party Preferences in Great Britain and Germany. American Journal of Political Science, 57(4): 841-857.

Bonardi, J.-P. 2011. Corporate political resources and the resource-based view of the firm. Strategic Organization, 9(3): 247-255.

Bonardi, J.-P., Hillman, A. J., \& Keim, G. D. 2005. The Attractiveness of Political Markets: Implications for Firm Strategy. The Academy of Management Review, 30(2): 397-413. Bonardi, J.-P., Holburn, G. L. F., \& Bergh, R. G. V. 2006. Nonmarket Strategy Performance: Evidence from U.S. Electric Utilities. The Academy of Management Journal, 49(6): 1209-1228. 
Bonardi, J.-P., \& Keim, G. D. 2005. Corporate Political Strategies for Widely Salient Issues. The Academy of Management Review, 30(3): 555-576.

Bosse, D. A., \& Phillips, R. A. 2016. Agency Theory and Bounded Self-Interest. Academy of Management Review, 41(2): 276-297.

Boyd, B. 1990. Corporate Linkages and Organizational Environment: A Test of the Resource Dependence Model. Strategic Management Journal, 11(6): 419-430.

Boyd, B. K., \& Salamin, A. 2001. Strategic Reward Systems: A Contingency Model of Pay System Design. Strategic Management Journal, 22(8): 777-792.

Brown, J. L., Drake, K., \& Wellman, L. 2015. The Benefits of a Relational Approach to Corporate Political Activity: Evidence from Political Contributions to Tax Policymakers. The Journal of the American Taxation Association, 37(1): 69-102.

Bruton, G. D., Fried, V. H., \& Manigart, S. 2005. Institutional influences on the worldwide expansion of venture capital. Entrepreneurship Theory and Practice, 29(6): 737-760.

Bundy, J., Shropshire, C., \& Buchholtz, A. K. 2013. Strategic cognition and issue salience: Toward an explanation of firm responsiveness to stakeholder concerns. Academy of Management Review, 38(3): 352-376.

Busenitz, L. W., \& Barney, J. B. 1997. Differences between entrepreneurs and managers in large organizations: Biases and heuristics in strategic decision-making. Journal of Business Venturing, 12(1): 9-30.

Casciaro, T., \& Piskorski, M. J. 2005. Power Imbalance, Mutual Dependence, and Constraint Absorption: A Closer Look at Resource Dependence Theory. Administrative Science Quarterly, 50(2): 167-199. 
Chandler, D. 2014. Organizational Susceptibility to Institutional Complexity: Critical Events Driving the Adoption and Implementation of the Ethics and Compliance Officer Position. Organization Science, 25(6): 1722-1743.

Chappell, B. 2014. 'Cromnibus' Spending Bill Passes, Just Hours Before Deadline. National Public Radio. https://www.npr.org/sections/thetwo-way/2014/12/11/370132039/housepoised-to-vote-on-controversial-cromnibus-spending-bill, December 11.

Child, J. 1972. Organizational Structure, Environment and Performance: The Role of Strategic Choice. Sociology, 6(1): 1-22.

Choi, S. J., Jia, N., \& Lu, J. Y. 2015. The Structure of Political Institutions and Effectiveness of Corporate Political Lobbying. Organization Science, 26(1): 158-179.

Chrisman, J. J., Chua, J. H., Kellermanns, F. W., \& Chang, E. P. C. 2007. Are family managers agents or stewards? An exploratory study in privately held family firms. Journal of Business Research, 60(10): 1030-1038.

Clayton, M. C., \& Bower, J. L. 1996. Customer Power, Strategic Investment, and the Failure of Leading Firms. Strategic Management Journal, 17(3): 197-218.

Coontz, S. 2014. Why America changed its mind on gay marriage, CNN.

Cooper, M. J., Gulen, H., \& Ovtchinnikov, A. V. 2010. Corporate Political Contributions and Stock Returns. The Journal of Finance, 65(2): 687-724.

Cox, G. W., \& Katz, J. N. 1996. Why did the incumbency advantage in US House elections grow? American Journal of Political Science, 40(2): 478-497.

Croco, S. E. 2016. The Flipside of Flip-Flopping: Leader Inconsistency, Citizen Preferences, and the War in Iraq. Foreign Policy Analysis, 12(3): 237-257. 
Currim, I. S., Lim, J., \& Kim, J. W. 2012. You Get What You Pay For: The Effect of Top Executives' Compensation on Advertising and R\&D Spending Decisions and Stock Market Return. Journal of Marketing, 76(5): 33-48.

Dalley, P. J. 2011. A Theory of Agency Law. University of Pittsburgh Law Review, 72(3): 495547.

Dalton, D. R., Daily, C. M., Certo, S. T., \& Roengpitya, R. 2003. Meta-analyses of financial performance and equity: Fusion or confusion? Academy of Management Journal, 46(1): $13-26$.

Davis, J. H., Schoorman, F. D., \& Donaldson, L. 1997. Toward a stewardship theory of management. Academy of Management Review, 22(1): 20-47.

DelReal, J. A., \& Clement, S. 2017. Rural Divide, Washington Post, June 17 ed. den Hond, F., Rehbein, K. A., de Bakker, F. G. A., \& Lankveld, H. K.-v. 2014. Playing on Two Chessboards: Reputation Effects between Corporate Social Responsibility (CSR) and Corporate Political Activity (CPA). Journal of Management Studies, 51(5): 790-813.

Dess, G. G., \& Beard, D. W. 1984. Dimensions of organizational task environments. Administrative Science Quarterly, 29(1): 52-73.

DiMaggio, P. J., \& Powell, W. W. 1983. The Iron Cage Revisited: Institutional Isomorphism and Collective Rationality in Organizational Fields. American Sociological Review, 48(2): $147-160$.

Doherty, D., Dowling, C. M., \& Miller, M. G. 2016. When is Changing Policy Positions Costly for Politicians? Experimental Evidence. Political Behavior, 38(2): 455-484.

Dushnitsky, G., \& Lenox, M. J. 2005. When do firms undertake R\&D by investing in new ventures? Strategic Management Journal, 26(10): 947-965. 
Eisenhardt, K. M. 1989. Agency Theory: An Assessment and Review. The Academy of Management Review, 14(1): 57-74.

Ellis, S., Aharonson, B. S., Drori, I., \& Shapira, Z. 2017. Imprinting through Inheritance: A Multi-Genealogical Study of Entrepreneurial Proclivity. Academy of Management Journal, 60(2): 500-522.

Finkelstein, S., \& Boyd, B. K. 1998. How much does the CEO matter? The role of managerial discretion in the setting of CEO compensation. Academy of Management Journal, 41(2): 179-199.

Finkelstein, S., \& Hambrick, D. C. 1990. Top-Management-Team Tenure and Organizational Outcomes: The Moderating Role of Managerial Discretion. Administrative Science Quarterly, 35(3): 484-503.

Flammer, C. 2018. Competing for Government Procurement Contracts: The Role of Corporate Social Responsibility. Strategic Management Journal doi: 10.1002/smj.2767.

Foss, N. J., \& Lindenberg, S. 2013. Microfoundations for strategy: A goal-framing perspective on the drivers of value creation. Academy of Management Perspectives, 27(2): 85-102.

Frynas, J. G., Mellahi, K., \& Pigman, G. A. 2006. First mover advantages in international business and firm-specific political resources. Strategic Management Journal, 27(4): 321-345.

Gaioni, M. S. 2012. Federal Anticorruption Law in the State and Local Context: Defining the Scope of 18 U.S.C. 666. Columbia Journal of Law and Social Problems, 46(2): 207249.

Gavetti, G., Greve, H. R., Levinthal, D. A., \& Ocasio, W. 2012. The Behavioral Theory of the Firm: Assessment and Prospects. Academy of Management Annals, 6(1): 1-40. 
Getz, K. 2001. Public affairs and political strategy: Theoretical foundations. Journal of public affairs, 1(4): 305-329.

Ghoshal, S. 2005. Bad Management Theories Are Destroying Good Management Practices. Academy of Management Learning \& Education, 4(1): 75-91.

Gomez-Mejia, L. R., \& Balkin, D. B. 1992. Determinants of Faculty Pay: An Agency Theory Perspective. The Academy of Management Journal, 35(5): 921-955.

Gomez, P. Y., \& Jones, B. C. 2000. Conventions: An interpretation of deep structure in organizations. Organization Science, 11(6): 696-708.

Green, S. G., \& Welsh, M. A. 1988. Cybernetics and Dependence: Reframing the Control Concept. The Academy of Management Review, 13(2): 287-301.

Groseclose, T., Levitt, S. D., \& Snyder, J. M. 1999. Comparing interest group scores across time and chambers: Adjusted ADA scores for the US congress. American Political Science Review, 93(1): 33-50.

Hadani, M. 2012. Institutional ownership monitoring and corporate political activity: Governance implications. Journal of Business Research, 65(7): 944-950.

Hadani, M., Bonardi, J.-P., \& Dahan, N. M. 2017. Corporate political activity, public policy uncertainty, and firm outcomes: A meta-analysis. Strategic Organization, 15(3): 338366.

Hadani, M., Dahan, N. M., \& Doh, J. P. 2015. The CEO as chief political officer: Managerial discretion and corporate political activity. Journal of Business Research, 68(11): 23302337.

Hadani, M., \& Schuler, D. A. 2013. In search of El Dorado: The elusive financial returns on corporate political investments. Strategic Management Journal, 34(2): 165-181. 
Hagen, J. M., \& Choe, S. 1998. Trust in Japanese Interfirm Relations: Institutional Sanctions Matter. The Academy of Management Review, 23(3): 589-600.

Hall, R. L., \& Deardorff, A. V. 2006. Lobbying as Legislative Subsidy. The American Political Science Review, 100(1): 69-84.

Hall, R. L., \& Reynolds, M. E. 2012. Targeted Issue Advertising and Legislative Strategy: The Inside Ends of Outside Lobbying. Journal of Politics, 74(3): 888-902.

Hambrick, D. C., \& Finkelstein, S. 1987. Managerial Discretion: A Bridge Between Polar Views of Organizational Outcomes. Research in Organizational Behavior, 9: 369-406.

Hansen, W. L., \& Mitchell, N. J. 2000. Disaggregating and Explaining Corporate Political Activity: Domestic and Foreign Corporations in National Politics. The American Political Science Review, 94(4): 891-903.

Hansen, W. L., Mitchell, N. J., \& Drope, J. M. 2005. The logic of private and collective action. American Journal of Political Science, 49(1): 150-167.

Hansen, W. L., Rocca, M. S., \& Ortiz, B. L. 2015. The Effects of Citizens United on Corporate Spending in the 2012 Presidential Election. The Journal of Politics, 77(2): 535-545.

Harbridge, L., \& Malhotra, N. 2011. Electoral Incentives and Partisan Conflict in Congress: Evidence from Survey Experiments. American Journal of Political Science, 55(3): 494510.

Harmon-Jones, E. 2002. A Cognitive Dissonance Theory Perspective on Persuasion. In J. P. Dillard, \& M. Pfau (Eds.), The Persuasion Handbook: Developments in Theory and Practice: 101. Thousand Oaks, CA: Sage Publications.

Hart, D. A. 2004. "Business" is not an interestgroup: On the study of companies in American national politics. Annual Review of Political Science, 7: 47-69. 
Hassell, H. J. G. 2016. Party Control of Party Primaries: Party Influence in Nominations for the US Senate. The Journal of politics, 78(1): 75-87.

Hernandez, M. 2012. Toward an Understanding of The Psychology of Stewardship. Academy of Management Review, 37(2): 172-193.

Hershey, M. R. 2007. Party Politics in America: Pearson Longman.

Hillman, A. J. 2005. Politicians on the board of directors: Do connections affect the bottom line? Journal of Management, 31(3): 464-481.

Hillman, A. J., \& Hitt, M. A. 1999. Corporate Political Strategy Formulation: A Model of Approach, Participation, and Strategy Decisions. The Academy of Management Review, 24(4): $825-842$.

Hillman, A. J., Keim, G. D., \& Schuler, D. 2004. Corporate Political Activity: A Review and Research Agenda. Journal of Management, 30(6): 837-857.

Hillman, A. J., Withers, M. C., \& Collins, B. J. 2009. Resource Dependence Theory: A Review. Journal of Management, 35(6): 1404-1427.

Hillman, A. J., Zardkoohi, A., \& Bierman, L. 1999. Corporate political strategies and firm performance: indications of firm-specific benefits from personal service in the U.S. government. Strategic Management Journal, 20(1): 67-81.

Hojnacki, M., Kimball, D. C., Baumgartner, F. R., Berry, J. M., \& Leech, B. L. 2012. Studying Organizational Advocacy and Influence: Reexamining Interest Group Research. In M. Levi (Ed.), Annual Review of Political Science, Vol 15, Vol. 15: 379-399. Palo Alto: Annual Reviews.

Holburn, G. L. F., \& Bergh, R. G. V. 2008. Making Friends in Hostile Environments: Political Strategy in Regulated Industries. The Academy of Management Review, 33(2): 521-540. 
Holburn, G. L. F., \& Vanden Bergh, R. G. 2008. Making Friends in Hostile Environments: Political Strategy in Regulated Industries. The Academy of Management Review, 33(2): 521-540.

Hoskisson, R. E., Wan, W. P., Yiu, D., \& Hitt, M. A. 1999. Theory and research in strategic management: swings of a pendulum. Journal of Management, 25(3): 417-456.

Houthoofd, N., \& Heene, A. 1997. Strategic Groups as Subsets of Strategic Scope Groups in the Belgian Brewing Industry. Strategic Management Journal (1986-1998), 18(8): 653.

Hsu, D. H. 2004. What do entrepreneurs pay for venture capital affiliation? Journal of Finance, 59(4): 1805-1844.

Huang, J.-W., \& Li, Y.-H. 2012. Slack resources in team learning and project performance. Journal of Business Research, 65(3): 381-388.

Iyengar, S., \& Hahn, K. S. 2009. Red Media, Blue Media: Evidence of Ideological Selectivity in Media Use. Journal of Communication, 59(1): 19-U16.

Jacobson, G. C. 2013. How the Economy and Partisanship Shaped the 2012 Presidential and Congressional Elections PRESIDENTIAL AND CONGRESSIONAL ELECTIONS. Political science quarterly, 128(1): 1-38.

Jayachandran, S., Kalaignanam, K., \& Eilert, M. 2013. Product and environmental social performance: Varying effect on firm performance. Strategic Management Journal, 34(10): 1255-1264.

Johnson, S., \& Kwak, J. 2013. 13 Bankers: The Wall Street Takeover and the Next Financial Meltdown. New York: Pantheon. 
Julian, S. D., \& Ofori-dankwa, J. C. 2013. Financial resource availability and corporate social responsibility expenditures in a sub-Saharan economy: The institutional difference hypothesis. Strategic Management Journal, 34(11): 1314-1330.

Julian, S. D., Ofori-Dankwa, J. C., \& Justis, R. T. 2008. Understanding Strategic Responses to Interest Group Pressures. Strategic Management Journal, 29(9): 963-984.

Karniouchina, E. V., Carson, S. J., Short, J. C., \& Ketchen, D. J. 2013. Extending the firm vs. industry debate: Does industry life cycle stage matter? Strategic Management Journal, 34(8): 1010-1018.

Kast, F. E., \& Rosenzweig, J. E. 1972. General Systems Theory: Applications for Organization and Management. The Academy of Management Journal, 15(4): 447-465.

Kim, H., Kim, H., \& Lee, P. M. 2008. Ownership structure and the relationship between financial slack and R\&D investments: Evidence from Korean firms. Organization Science, 19(3): 404-418.

Kingsley, A. F., Vanden Bergh, R. G., \& Bonardi, J. P. 2012. Political Markets and Regulatory Uncertainty: Insights and Implications for Integrated Strategy. Academy of Management Perspectives, 26(3): 52-67.

Kroszner, R. S., \& Stratmann, T. 1998. Interest-Group Competition and the Organization of Congress: Theory and Evidence from Financial Services' Political Action Committees. American Economic Review, 88(5): 1163-1187.

Kunze, F., de Jong, S. B., \& Bruch, H. 2016. Consequences of Collective-Focused Leadership and Differentiated Individual-Focused Leadership: Development and Testing of an Organizational-Level Model. Journal of Management, 42(4): 886-914. 
Lado, A. A., Boyd, N. G., \& Hanlon, S. C. 1997. Competition, Cooperation, and the Search for Economic Rents: A Syncretic Model. The Academy of Management Review, 22(1): 110141.

Laffont, J. J., \& Tirole, J. 1991. The Politics of Government Decision-Making: A theory of regulatory capture. Quarterly Journal of Economics, 106(4): 1089-1127.

Lan, L. L., \& Heracleous, L. 2010. Rethinking Agency Theory: The View from Law. Academy of Management Review, 35(2): 294-314.

Lee, J. J. 2010. Heterogeneity, Brokerage, and Innovative Performance: Endogenous Formation of Collaborative Inventor Networks. Organization Science, 21(4): 804-822.

Lenway, S. A., \& Rehbein, K. 1991. Leaders, Followers, and Free riders: An empirical-test of variation in corporate political involvement. Academy of Management Journal, 34(4): 893-905.

Lester, R. H., Hillman, A., Zardkoohi, A., \& Cannella, J., Albert A. 2008. Former Government Officials as outside Directors: The Role of Human and Social Capital. The Academy of Management Journal, 51(5): 999-1013.

Levine, M. E., \& Forrence, J. L. 1990. Regulatory Capture, Public-Interest, and the Public Agenda: Toward a Synthesis. Journal of Law Economics \& Organization, 6: 167-198.

Liao, C., Wayne, S. J., Liden, R. C., \& Meuser, J. D. 2017. Idiosyncratic deals and individual effectiveness: The moderating role of leader-member exchange differentiation. The Leadership Quarterly, 28(3): 438-450.

Lindeque, J. P., \& McGuire, S. M. 2010. Non-market Capabilities and the Prosecution of Trade Remedy Cases in the United States. Journal of World Trade, 44(4): 903-930. 
Lord, M. D. 2000. Corporate Political Strategy and Legislative Decision Making. Business \& Society, 39(1): 76-93.

Love, E. G., \& Nohria, N. 2005. Reducing slack: The performance consequences of downsizing by large industrial firms, 1977-93. Strategic Management Journal, 26(12): 1087-1108.

Lubell, M., Feiock, R. C., \& de la Cruz, E. E. R. 2009. Local Institutions and the Politics of Urban Growth. American Journal of Political Science, 53(3): 649-665.

Luo, Y. D. 2003. Industrial dynamics and managerial networking in an emerging market: The case of China. Strategic Management Journal, 24(13): 1315-1327.

Maestas, C. D., Fulton, S., Maisel, L. S., \& Stone, W. J. 2006. When to Risk It? Institutions, Ambitions, and the Decision to Run for the U.S. House. The American Political Science Review, 100(2): 195-208.

Mahoney, J. T., McGahan, A. M., \& Pitelis, C. N. 2009. The Interdependence of Private and Public Interests. Organization Science, 20(6): 1034-1052.

Marcus, G. E., \& Mackuen, M. B. 1993. Anxiety, Enthusiasm, and the Vote - The Emotional Underpinnings of Learning and Involvement during Presidential Campaigns. American Political Science Review, 87(3): 672-685.

Marín, L., Rubio, A., \& de Maya, S. R. 2012. Competitiveness as a Strategic Outcome of Corporate Social Responsibility. Corporate Social Responsibility and Environmental Management, 19(6): 364-376.

Marquis, C., \& Qian, C. L. 2014. Corporate Social Responsibility Reporting in China: Symbol or Substance? Organization Science, 25(1): 127-148.

Matsubayashi, T. 2013. Do Politicians Shape Public Opinion? British Journal of Political Science, 43(02): 451-478. 
Matta, E., \& McGuire, J. 2008. Too risky to hold? The effect of downside risk, accumulated equity wealth, and firm performance on CEO equity reduction. Organization Science, 19(4): 567-580.

McDonnell, M.-H., \& Werner, T. 2016. Blacklisted Businesses. Administrative Science Quarterly, 61(4): 584-620.

McGahan, A. M., \& Porter, M. E. 1997. How much does industry matter, really? Strategic Management Journal, 18: 15-30.

McGraw, K. M., Lodge, M., \& Jones, J. M. 2002. The pandering politicians of suspicious minds. Journal of Politics, 64(2): 362-383.

McKay, A. 2012. Buying Policy? The Effects of Lobbyists' Resources on Their Policy Success. Political Research Quarterly, 65(4): 908-923.

McKee, S. C., \& Teigen, J. M. 2009. Probing the reds and blues: Sectionalism and voter location in the 2000 and 2004 U. S. presidential elections. Political Geography, 28(8): 484-495.

McNamara, G., Deephouse, D. L., \& Luce, R. A. 2003. Competitive positioning within and across a strategic group structure: The performance of core, secondary and solitary firms. Strategic Management Journal, 24(2): 161-181.

Mellahi, K., Frynas, J. G., Sun, P., \& Siegel, D. 2016. A Review of the Nonmarket Strategy Literature: Toward a Multi-Theoretical Integration. Journal of Management, 42(1): 143173.

Meyer, J. W., \& Rowan, B. 1977. Institutionalized Organizations: Formal Structure as Myth and Ceremony. American Journal of Sociology, 83(2): 340-363. 
Meznar, M. B., \& Nigh, D. 1995. BUFFER OR BRIDGE - ENVIRONMENTAL AND ORGANIZATIONAL DETERMINANTS OF PUBLIC AFFAIRS ACTIVITIES IN AMERICAN FIRMS. Academy of Management Journal, 38(4): 975-996.

Miller, D., Breton-Miller, I. L., \& Lester, R. H. 2013. Family Firm Governance, Strategic Conformity, and Performance: Institutional vs. Strategic Perspectives. Organization Science, 24(1): 189-209.

Mosk, M., Ross, B., Epstein, B., \& Park, C. 2016. 'FOBs': How Hillary's State Dept. Gave Special Attention to 'Friends of Bill' After Haiti Quake. http://abcnews.go.com/Politics/fobs-hillarys-state-dept-gave-special-attentionfriends/story?id=42615379.

Moulick, A. G., \& Taylor, L. L. 2017. Fiscal slack, budget shocks, and performance in public organizations: evidence from public schools. Public Management Review, 19(7): 9901005.

Mullins, B., \& Zimmerman, A. 2010. Target Discovers Downside to Political Contributions, Wall Street Journal. August 7.

Natividad, G. 2013. Financial Slack, Strategy, and Competition in Movie Distribution. Organization Science, 24(3): 846-864.

Néron, P.-Y. 2009. Business and the Polis: What Does it Mean to See Corporations as Political Actors? Journal of Business Ethics, 94(3): 333-352.

Nigam, A., \& Ocasio, W. 2010. Event Attention, Environmental Sensemaking, and Change in Institutional Logics: An Inductive Analysis of the Effects of Public Attention to Clinton's Health Care Reform Initiative. Organization Science, 21(4): 823-841. 
Nyberg, A. J., Fulmer, I. S., Gerhart, B., \& Carpenter, M. A. 2010. Agency Theory Revisited: CEO Return and Shareholder Interest Alignment. Academy of Management Journal, 53(5): 1029-1049.

Ofori-Dankwa, J., \& Julian, S. D. 2013. Dynamism, Capital Structure, and Performance in a Sub-Saharan Economy: Extending the Institutional Difference Hypothesis. Organization Science, 24(5): 1422-1438.

Oh, W.-Y., Chang, Y. K., \& Kim, T.-Y. 2016. Complementary or Substitutive Effects? Corporate Governance Mechanisms and Corporate Social Responsibility. Journal of Management, http://journals.sagepub.com/doi/10.1177/0149206316653804, June 20.

Oldroyd, J. B., \& Morris, S. S. 2012. CATCHING FALLING STARS: A HUMAN RESOURCE RESPONSE TO SOCIAL CAPITAL'S DETRIMENTAL EFFECT OF INFORMATION OVERLOAD ON STAR EMPLOYEES. Academy of Management Review, 37(3): 396418.

Oliver, C. 1991. Strategic Responses to Institutional Processes. The Academy of Management Review, 16(1): 145-179.

Olson, M. 1965. The Logic of Collective Action. Cambridge: Harvard University Press.

Pajunen, K. 2006. Stakeholder Influences in Organizational Survival. Journal of Management Studies, 43(6): 1261-1288.

Palazzolo, D. J., \& Moscardelli, V. G. 2006. Policy crisis and political leadership: Election law reform in the states after the 2000 presidential election. State Politics \& Policy Quarterly, 6(3): 300-321. 
Pearce, J. L., Castro, J. O. D., \& Guillén, M. F. 2008. Introduction to Special Topic Forum: Influencing Politics and Political Systems: Political Systems and Corporate Strategies. The Academy of Management Review, 33(2): 493-495.

Peksen, D., Blanton, S. L., \& Blanton, R. G. 2017. Neoliberal Policies and Human Trafficking for Labor: Free Markets, Unfree Workers? Political Research Quarterly, 70(3): 673-686.

Pepper, A., \& Gore, J. 2015. Behavioral Agency Theory: New Foundations for Theorizing About Executive Compensation. Journal of Management, 41(4): 1045-1068.

Peress, M. 2013. Candidate positioning and responsiveness to constituent opinion in the U.S. House of Representatives. Public Choice, 156(1-2): 77-94.

Permanent Subcommittee on Investigations, U. S. S. 2011. Wall Street and the Financial Crisis: Anatomy of a Financial Collapse. Washington, D.C.

Perry, J., \& McWhirter, C. 2010. PACs stick with incumbents, Atlanta Journal-Constitution. Atlanta.

Pfeffer, J., \& Salancik, G. R. 2003. The External Control of Organizations: A Resource Dependence Perspective: Stanford Business Books.

Poe, S. 2013. Enterprising States 2013 Report: Top Performers in Business Climate. U.S. Chamber of Commerce Foundation. https://www.uschamberfoundation.org/blog/post/enterprising-states-2013-report-topperformers-business-climate/34302, May 13.

Porter, M. E. 1980. Competitive Strategy. New York: Free Press.

Preacher, K. J., \& Hayes, A. F. 2004. SPSS and SAS procedures for estimating indirect effects in simple mediation models. Behavior Research Methods Instruments \& Computers, 36(4): 717-731. 
Pugliese, A., Minichilli, A., \& Zattoni, A. 2014. Integrating agency and resource dependence theory: Firm profitability, industry regulation, and board task performance. Journal of Business Research, 67(6): 1189-1200.

Quinn, E., \& Young, C. 2015. D.C. Influencers Spend More on Advertising and PR Than Lobbying. http://time.com/3668128/lobbying-advertising-public-relations/, first accessed February 11, 2017.

Rajagopalan, N. 1997. Strategic orientations, incentive plan adoptions, and firm performance: Evidence from electric utility firms. Strategic Management Journal, 18(10): 761-785. Ramarajan, L., Rothbard, N. P., \& Wilk, S. L. 2017. Discordant vs. Harmonious Selves: The Effects of Identity Conflict and Enhancement on Sales Performance in EmployeeCustomer Interactions. Academy of Management Journal, 60(6): 2208-2238.

Rerup, C. 2009. Attentional triangulation: learning from unexpected rare crises. Organization Science, 20: $876+$.

Rodríguez, A., \& Nieto, M. J. 2016. Does R\&D offshoring lead to SME growth? Different governance modes and the mediating role of innovation. Strategic Management Journal, 37(8): 1734-1753.

Rogan, M., \& Greve, H. R. 2015. Resource Dependence Dynamics: Partner Reactions to Mergers. Organization Science, 26(1): 239-255.

Rumelt, R. P., Schendel, D., \& Teece, D. J. 1991. Strategic Management and Economics. Strategic Management Journal, 12: 5-29.

Schaffner, B. F. 2006. Local news coverage and the incumbency advantage in the US House. Legislative Studies Quarterly, 31(4): 491-511. 
Schuler, D. A. 1996. Corporate political strategy and foreign competition: The case of the steel industry. Academy of Management Journal, 39(3): 720-737.

Schuler, D. A., Rehbein, K., \& Cramer, R. D. 2002. Pursuing strategic advantage through political means: A multivariate approach. Academy of Management Journal, 45(4): 659672.

Schulze, W. S., Lubatkin, M. H., Dino, R. N., \& Buchholtz, A. K. 2001. Agency Relationships in Family Firms: Theory and Evidence. Organization Science, 12(2): 99-116.

Scott, W. R. 2004. Reflections on a Half-Century of Organizational Sociology. Annual Review of Sociology, 30: xii-21.

Shaffer, B. 1995. Firm-level Responses to Government Regulation: Theoretical and Research Approaches. Journal of Management, 21(3): 495-514.

Shaffer, B., \& Hillman, A. J. 2000. The development of business-government strategies by diversified firms. Strategic Management Journal, 21(2): 175-190.

Shan, L., Fu, S., \& Zheng, L. 2017. Corporate sexual equality and firm performance. Strategic Management Journal, 38(9): 1812-1826.

Shane, S. 2001. Organizational incentives and organizational mortality. Organization Science, 12(2): 136-160.

Sieger, P., Zellweger, T., \& Aquino, K. 2013. Turning Agents into Psychological Principals: Aligning Interests of Non-Owners through Psychological Ownership. Journal of Management Studies, 50(3): 361-388.

Simons, T., \& Ingram, P. 2004. An ecology of ideology: theory and evidence from four populations. Industrial and Corporate Change, 13(1): 33-59. 
Sobel, M. E. 1982. Asymptotic Confidence Intervals for Indirect Effects in Structural Equation Models. Sociological Methodology, 13: 290-312.

Sokhey, A. E., \& McClurg, S. D. 2012. Social Networks and Correct Voting. Journal of Politics, 74(3): 751-764.

Stevens, C. E., Xie, E., \& Peng, M. W. 2016. Toward a legitimacy-based view of political risk: The case of Google and Yahoo in China. Strategic Management Journal, 37(5): 945963.

Stevens, J. M., Kevin Steensma, H., Harrison, D. A., \& Cochran, P. L. 2005. Symbolic or substantive document? The influence of ethics codes on financial executives' decisions. Strategic Management Journal, 26(2): 181-195.

Stratmann, T., \& Verret, J. W. 2015. How Does Corporate Political Activity Allowed by Citizens United v. Federal Election Commission Affect Shareholder Wealth? Journal of Law \& Economics, 58(3): 545-559.

Strauss, G., \& Hanson, M. 1997. American anti-management theories of organization: A critique of paradigm proliferation - Donaldson,L. Human Relations, 50(9): 1177-1190.

Suchman, M. C. 1995. Managing Legitimacy: Strategic and Institutional Approaches. The Academy of Management Review, 20(3): 571-610.

Sulkin, T. 2009. Campaign Appeals and Legislative Action. Journal of Politics, 71(3): 10931108.

Tan, J., \& Peng, M. W. 2003. Organizational slack and firm performance during economic transitions: Two studies from an emerging economy. Strategic Management Journal, 24(13): 1249-1263. 
The Center for Responsive Politics. 2017. Lobbying Database.

https://www.opensecrets.org/lobby/, first accessed February 11, 2017.

Thomsen, D. M. 2014. Ideological Moderates Won't Run: How Party Fit Matters for Partisan Polarization in Congress. Journal of Politics, 76(3): 786-797.

Transcanada Corporation. 2010. U.S. Pipeline Contractors Association and Unions Pledge Their Support for Keystone XL Project. http://www.transcanada.com/announcementsarticle.html?id=1318593, first accessed February 12, 2017.

Tumbull, D. 2016. The American Petroleum Institute's Desperate PR is Failing. Oil Change International. http://priceofoil.org/2016/08/24/american-petroleum-instutes-desperate-pris-failing/, August 24.

U.S. Chamber of Commerce Foundation. 2013. Enterprising States: Getting Down to Small Business. https://www.uschamberfoundation.org/sites/default/files/legacy/foundation/ES2013.pdf, last accessed May 14, 2018.

United States Department of Labor. 2016. https://www.osha.gov/pls/imis/sic_manual.html, accessed 3/13/2016.

Valentino, N. A., Brader, T., Groenendyk, E. W., Gregorowicz, K., \& Hutchings, V. L. 2011. Election Night's Alright for Fighting: The Role of Emotions in Political Participation. Journal of Politics, 73(1): 156-170.

Vavreck, L. 2016. So Just Who Are Those Undecided Voters? https://www.nytimes.com/2016/10/01/upshot/so-just-who-are-these-undecidedvoters.html?_r=0, first accessed February 12, 2017. 
Wangrow, D. B., Schepker, D. J., \& Barker, V. L. 2015. Managerial Discretion: An Empirical Review and Focus on Future Research Directions. Journal of Management, 41(1): 99135.

Wasserman, D., \& Finn, A. 2017. Introducing the 2017 Cook Political Report Partisan Voter Index. https://www.cookpolitical.com/introducing-2017-cook-political-report-partisanvoter-index, April 7.

Wefald, A. J., Katz, J. P., Downey, R. G., \& Rust, K. G. 2010. Organizational slack, firm performance, and the role of industry. Journal of Managerial Issues, 22(1): 70-87.

Weisensee, N. 1991. Lawmaker, Teamster Collide Over Multi-trailer Law, The Morning Call. Williams-Wyche, S. N. 2014. An empirical test of presidentialism's effect on party competition. Electoral Studies, 33(0): 166-174.

Williamson, O. E. 1981. The Economics of Organization: The Transaction Cost Approach. American Journal of Sociology, 87(3): 548-577.

Williamson, O. E. 1985. The Economic Institutions of Capitalism: Firms, Markets, Relational Contracting. New York: Free Press.

Wry, T., Cobb, J. A., \& Aldrich, H. E. 2013. More than a Metaphor: Assessing the Historical Legacy of Resource Dependence and its Contemporary Promise as a Theory of Environmental Complexity. Academy of Management Annals, 7(1): 441-488.

Xu, E. M., Yang, H., Quan, J. M., \& Lu, Y. 2015. Organizational slack and corporate social performance: Empirical evidence from China's public firms. Asia Pacific Journal of Management, 32(1): 181-198.

Yackee, J. W., \& Yackee, S. W. 2006. A bias towards business? Assessing interest group influence on the US bureaucracy. Journal of Politics, 68(1): 128-139. 
Yeo, S. K., Xenos, M. A., Brossard, D., \& Scheufele, D. A. 2015. Selecting Our Own Science: How Communication Contexts and Individual Traits Shape Information Seeking. Annals of the American Academy of Political and Social Science, 658(1): 172-191.

Yglesias, M. 2014. AFL-CIO Backs Keystone XL. http://www.slate.com/blogs/moneybox/2014/02/06/afl_cio_and_keystone_why_labor_lik es pipelines.html, first accessed February 12, 2017.

Zetlin, M. 2018. 9 Ways the Government Shutdown Could Affect Your Small Business. Inc. https://www.inc.com/minda-zetlin/9-ways-government-shutdown-could-affect-yoursmall-business.html, January 20.

Zhang, J., Marquis, C., \& Qiao, K. 2016. Do Political Connections Buffer Firms from or Bind Firms to the Government? A Study of Corporate Charitable Donations of Chinese Firms. Organization science, 27(5): 1307-1324.

Zhao, X., Lynch, J. G., \& Chen, Q. 2010. Reconsidering Baron and Kenny: Myths and Truths about Mediation Analysis. The Journal of consumer research, 37(2): 197-206. 


\section{ABSTRACT \\ THE POLITICAL LANDSCAPE: A NEW APPROACH TO UNDERSTANDING CORPORATE POLITICAL ACTIVITY}

by

\section{MICHAEL GREINER}

\section{August 2018}

Advisor: Dr. Jaegul Lee

Major: Business Administration (Management Strategy)

Degree: Doctor of Philosophy

Despite the fact that Corporate Political Activity (CPA) is an area of research generating increasing interest among both academics and practitioners, there has been relatively little empirical research in the field, and what research has been done has often been inconclusive. In this dissertation, I argue that prior research has been hampered by a theory that relies upon a market analysis to understand this non-market activity. Instead, I describe and test a model of CPA in which business interests negotiate three factors in their efforts to convince politicians to support their positions: the ideology of the politician, the politician's relationships, and the political trends in the politician's constituency. I also argue that two institutions moderate CPA: strong political parties and the politicians' ideology. Relying upon agency theory, I argue that where top managers have the ability to behave opportunistically, they will be more likely to engage in CPA that targets politicians with more extreme ideologies rather than the undecided moderates. Such CPA might be personally satisfying to the managers, but it is unlikely to benefit the firm. I test these theories on a unique dataset and find support for them. This result brings more sophistication to understanding the mechanisms of CPA, while also helping to explain a problem that had previously 
puzzled scholars, namely why businesses engage in CPA when research has failed to find a link between CPA and firm performance in most industries.

Keywords: Corporate political activity; nonmarket strategies; public policy; agency theory 


\section{AUTOBIOGRAPHICAL STATEMENT}

Michael Greiner is a doctoral student at the Mike Ilitch School of Business of Wayne State University. He has presented five papers at the Academy of Management Conference. He holds a Juris Doctor from Wayne State University Law School, having graduated Magna Cum Laude, and he is a licensed attorney in the State of Michigan and the Federal Courts. He has extensive experience teaching business law at the college level. In addition to his academic credentials, he practiced Bankruptcy law for over a decade and founded several businesses. Prior to that, Michael pursued a career in politics and government working in several state capitals and the U.S. Congress, managing dozens of political campaigns, and serving nearly a decade as the Deputy Mayor of Michigan's third largest city. He is the author of several books aimed at nonacademic audiences and articles that appeared in the Wayne Law Review and the American Bankruptcy Institute Journal. Michael has recently accepted the position of Assistant Professor of Management at Oakland University in Rochester, Michigan. 